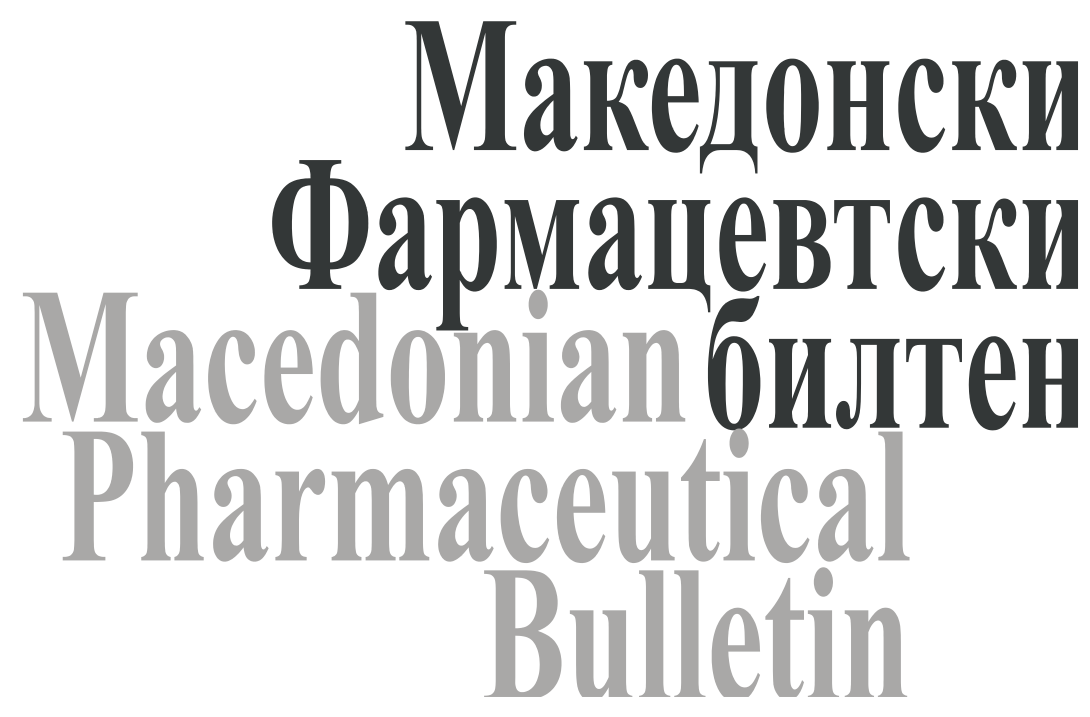

волумен 61 (1) 2015 / volume 61 (1) 2015

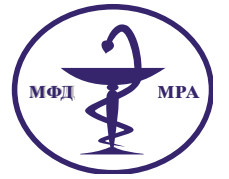

Македонско фармацевтско друштво, ул. Маршал Тито 13б/8, Скопје, Македонија Macedonian Pharmaceutical Association, Marshal Tito 13b/8, Skopje Macedonia 



\title{
Antimicrobial activity of berries and leaves essential oils of Macedonian Juniperus foetidissima Willd. (Cupressaceae)
}

\author{
Floresha Sela ${ }^{\mathrm{a}}$, Marija Karapandzova ${ }^{\mathrm{a}^{*}}$, Gjose Stefkov ${ }^{\mathrm{a}}$, Ivana Cvetkovikja , Elena Trajkovska-Dokikj ${ }^{\mathrm{b}}$, \\ Ana Kaftandzieva ${ }^{\mathrm{b}}$, Svetlana Kulevanova ${ }^{\mathrm{a}}$ \\ "Institute of Pharmacognosy, Faculty of Pharmacy, University "Ss. Cyril and Methodius", \\ Str. Majka Tereza 47, 1000 Skopje, R. Macedonia

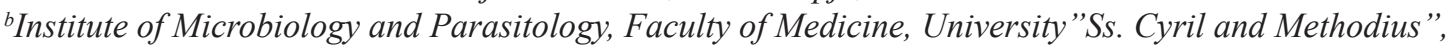 \\ Str. 50 Divizija No.6, 1000 Skopje, R. Macedonia
}

Received: January 2015; Accepted: April 2015

\begin{abstract}
Chemical composition and antimicrobial activity of leaves and berries essential oils from Juniperus foetidissima Willd. (Cupressaceae) grown in R. Macedonia (RM) was investigated. GC/FID/MS analysis was carried out and 93 components were identified, representing $89.7-96.5 \%$ of the oils. The major components of the berries essential oil were $\alpha$-pinene $(19.2 \%)$, limonene $(24.9 \%)$ and cedrol (23.1\%), followed by smaller amounts of $\beta$-funebrene, trans-caryophyllene, germacrene $\mathrm{D}$ and $\delta$-cadinene. The composition of the leaves essential oil was variable depending on the region of collection. Accordingly, samples originated from southeastern RM contained essential oil with $\alpha$-pinene $(67.6 \%)$ and limonene (10.0\%), from central part of RM with limonene (17.9-27.1\%) and cedrol (28.8-33.9\%), while samples from southwestern RM contained oil with terpinen-4-ol (19.1\%), cis-thujone (8.3\%), germacrene D (11.0\%) and $\delta$-cadinene $(6.3 \%)$ as predominant components in the oil. Antimicrobial screening of the essential oils was made by disc diffusion and broth dilution method against 16 bacterial strains of Gram-positive and Gram-negative bacteria and one strain of Candida albicans. The leaves essential oil showed stronger antimicrobial activity against Staphylococcus aureus, Streptococcus pyogenes and Haemophilus influenzae (MIC $=125$ $\mu \mathrm{l} / \mathrm{ml}$ ) and moderate activity against Campylobacter jejuni (MIC $>500 \mu \mathrm{l} / \mathrm{ml}$ ). Other investigated bacterial strains and Candida albicans were completely resistant to the antimicrobial activity of $J$. foetidissima essential oils.
\end{abstract}

Keywords: Juniperus foetidissima, leaves, berries, essential oil, GC/FID/MS composition, antimicrobial activity

\section{Introduction}

Juniperus is one of the major genera of Cupressaceae family consisting of approximately 70 species variable in size and shape, from tall trees to columnar or low spreading shrubs. The plants are evergreen with needle-like or scalelike leaves. Juniperus foetidissima Willd. is a medium-size tree, spread mainly throughout the southeastern Europe and southwestern Asia, starting from southeastern Albania and northern Greece, across Turkey, Syria and Lebanon to the northern Iran and southwestern Turkmenistan. It often

\footnotetext{
*Marija_Karapandzova@ff.ukim.edu.mk; marijakarapandzova@yahoo.com
}

occurs together with $J$. excelsa Bieb., but it could be distinguished by its thicker shoots and green leaves (Marcysiak et al., 2007). The name foetidissima comes from the stinking (fetid) smell of crushed leaves.

Traditionally Juniperus species are used for curing different disorders and pathological conditions. There are few investigations regarding the biological activities of $J$. foetidissima, with reports on antifungal (Balaban et al., 2003), antimicrobial (Asili et al., 2010), cytotoxic (Sadaeghi-Aliabdi et al., 2009), anticholinesterase (Ozturk et al., 2010), fumigant (Tayoub et al., 2012), anti-inflamatory (Orhan et al., 2012; Lesjak et al., 2013) and antioxidant effects (Lesjak et al., 2013; Emmami et al., 2007, Emami et al., 2011). These activities have been shown due to the complex che- 
mical pattern of terpene components.

$J$. foetidissima contains essential oil in almost all parts of the plant, with variable composition. Thus, sabinene, $\alpha$-thujone, terpinen-4-ol and $\gamma$-terpinene were reported as major components of the leaf essential oil of J. foetidissi$m a$ from Greece (Adams, 1987; Adams, 1990). The monoterpenes sabinene, $\alpha$-pinene and limonene were predominant components of the essential oils of fruits and leaves of male and female plant of $J$. foetidissima from Iran (Asili et al., 2010). Turkish J. foetidissima contained $\beta$-thujone and cedrol as major component in the leaf essential oil and sabinene as predominant in berry oil. The major components of seed and seedless cone berry oils were sabinene, $\beta$-thujone and abietal while in the oil from branches the most abundant was $\alpha$-pinene (Tunalier et al., 2002). On the other hand, J. foetidissima heartwood of the root and stem was identified as the new potential source of Cedarwood oil (Tunalier et al., 2004), while in the essential oil obtained from branches of J. foetidissima grown in Syria, citronellol, bornyl acetate and cadalene were found as major constituents (Tayoub et al., 2012). These oils are considered as potential sources of various terpene components as well as biologically active agent.

$J$. foetidissima occurs in the flora of Republic of Macedonia (RM). Mainly, it grows in southern parts of the country, but could be found in the valleys of the River Crn Drim and the River Treska in western and Karadzica Mtn. in central RM (Micevski, 1998). Up to now only one report on chemical composition, an antioxidant and anti-inflammatory effects of one sample of Macedonian J. foetidissima was published (Lesjak et al., 2013). The present study was aimed to determine the chemical composition and to evaluate the antimicrobial activity of the essential oils obtained from berries and leaves from $J$. foetidissima collected on several locations in RM.

\section{Material and methods}

\section{Plant materials}

The terminal plant twigs were collected from four different localities in RM (Table 1). Plant identity was verified as Juniperus foetidissima Willd. and herbarium vouch- er specimens were deposited at the Department of Pharmaceutical Botany, Institute of Pharmacognosy, Faculty of Pharmacy, Skopje, RM. The plant material was dried at room temperature. Just before hydroisolation, leaves and berries were separated from the branches and minced properly.

The plant material was collected from 4 localities from central (Veles), southern (Udovo), southeastern (Valandovo) and southwestern (Ohrid) RM. According to this the samples of leaves oils were marked as Ve-LEO, U-LEO, Val-LEO and Oh-LEO, respectively. The sample of berries essential oil was marked as Val-BEO (Table 1).

\section{Chemicals}

Dimethylsulfoxide was purchased from Sigma-Aldrich (Steinheim, Germany), sodium chloride and anhydrous sodium sulfate from Merck (Darmstadt, Germany) and from Kemica (Zagreb, Croatia), respectively, while xylene was purchased from Alkaloid (Skopje, RM).

\section{Essential oil isolation}

The essential oils were obtained from dried plant material through distilled stem using all glass Clevenger-type apparatus. For that purpose, $20 \mathrm{~g}$ of minced plant material was distilled for 4 hours. After isolation, anhydrous sodium sulfate was added to remove residual water from the oil. The essential oil yield was calculated on dried plant material and was expressed in $\mathrm{ml} / \mathrm{kg}$. For GC/FID/MS analysis, the essential oil was dissolved in xylene to obtain $1 \mu \mathrm{l} / \mathrm{ml}$ oil solution.

\section{Gas chromatography (GC) and gas chromatography/mass spectrometry $(G C / M S)$}

Essential oil samples were analyzed on Agilent 7890A Gas Chromatography system equipped with FID detector and Agilent 5975C Mass Quadrupole detector as well as capillary flow technology which enables simultaneous analysis of the samples on both detectors. For that purpose, HP-5ms capillary column $(30 \mathrm{~m} \times 0.25 \mathrm{~mm}$, film thickness $0.25 \mu \mathrm{m}$ ) was used. Operating conditions were as

Table 1. Plant material and samples of essential oil (LEO - leaves essential oil, BEO -berries essential oil)

\begin{tabular}{lccc}
\hline \hline \multicolumn{1}{c}{ Locality } & m.a.s.l. & $\begin{array}{c}\text { Voucher } \\
\text { specimen N }\end{array}$ & $\begin{array}{c}\text { Abbrev. in the } \\
\text { text }\end{array}$ \\
\hline $\begin{array}{l}\text { Region of Valandovo, southeastern RM } \\
\begin{array}{l}\text { v. Udovo, River Vardar (Axios), } \\
\text { south RM }\end{array}\end{array}$ & $100 \mathrm{~m}$ & $\mathrm{~N}^{\circ} \mathrm{JF}-1 / 11$ & Val-LEO \\
$\begin{array}{l}\text { Taorska Gorge, River Vardar (Axios), region of Veles, central RM } \\
\text { v. Velestovo, National Park Galichica, Ohrid Lake, southwestern RM. }\end{array}$ & $250 \mathrm{~m}$ & $\mathrm{~N}^{\circ} \mathrm{JF}-2 / 11$ & U-LEO \\
$\mathrm{N}^{\circ} \mathrm{JF}-3 / 11$ & Ve-LEO \\
\hline
\end{tabular}


follows: oven temperature at $60{ }^{\circ} \mathrm{C}(5 \mathrm{~min}), 1{ }^{\circ} \mathrm{C} / \mathrm{min}$ to $80{ }^{\circ} \mathrm{C}(2 \mathrm{~min})$ and $5{ }^{\circ} \mathrm{C} / \mathrm{min}$ to $280^{\circ} \mathrm{C}(5 \mathrm{~min})$; helium as carrier gas at a flow rate of $1 \mathrm{ml} / \mathrm{min}$; injector temperature $260{ }^{\circ} \mathrm{C}$ and that of the FID $270{ }^{\circ} \mathrm{C} .1 \mu \mathrm{l}$ of each sample was injected at split ratio $1: 1$. The mass spectrometry conditions were: ionization voltage $70 \mathrm{eV}$, ion source temperature $230{ }^{\circ} \mathrm{C}$, transfer line temperature $280{ }^{\circ} \mathrm{C}$ and mass range from 50 - $500 \mathrm{Da}$. The MS was operated in scan mode.

\section{Identification of the components}

Identification of the components present in essential oils was made by comparison of their mass spectra with those from Nist, Wiley and Adams mass spectra libraries, by AMDIS (Automated Mass Spectral Deconvolution and Identification System) and by comparing literature and estimated Kovat's (retention) indices that were determined using mixture of homologous series of normal alkanes from $\mathrm{C}_{9}$ to $\mathrm{C}_{25}$ in hexane, under the same above mentioned conditions.

The percentage ratio of essential oils components was computed by the normalization method of the GC/FID peak areas without any correction factors.

\section{Antimicrobial activity: Microbial strains and cultures}

16 bacterial isolates of Gram positive and Gram negative bacteria and one strain of Candida albicans were used for antimicrobial screening. Five isolates were standard strains (Staphylococcus aureus ATCC 29213, Escherichia coli 25927, Klebsiella pneumoniae ATCC 700603, Pseudomonas aeruginosa ATCC 27853 and Candida albicans ATCC 10231). The remaining 11 bacterial strains (Staphylococcus epidermidis, Enterococcus, Streptococcus pyogenes, Streptococcus agalactiae, Streptococcus pneumoniae, Haemophilus influenzae, Proteus mirabilis, Corynebacterium spp., Shigella flexneri, Campylobacter jejuni, Salmonella enteritidis and Acinetobacter spp.) were clinical isolates provided from the Institute of Microbiology and Parasitology, Faculty of Medicine, Skopje, R. Macedonia.

A nutrient (Mueller Hinton) agar from Merck (Darmstadt, Germany), blood agar (Oxoid, Basingstoke, UK) and Sabouraund agar (bioMerieux, Durham, NC) were used for growing of the microbial strains.

\section{Disc diffusion method}

Disc diffusion method was used for screening the antimicrobial activity of all essential oils in order to determine the growth inhibition zones of studied microorganisms that occur around certain essential oil. In this regard, microorganisms were suspended in sterile broth with turbidity corresponding to 0.5 and $1 \mathrm{Mc}$ Farland (approximate by $10^{7}-$ $10^{8} \mathrm{CFU} / \mathrm{ml}$ ) for all bacteria and for Candida albicans, respectively. The microbial suspensions were streaked over the surface of the agar media using a sterile cotton swabs to ensure uniform inoculation. After inoculation of microorganisms, discs of $6 \mathrm{~mm}$ in diameter were made at wellspaced intervals. They were filled with $85 \mu \mathrm{l}$ of $50 \%$ solutions of essential oils in dimethylsulfoxide (DMSO, Sigma-Aldrich, Germany) and one disc was filled only with DMSO as a control. The plates were incubated at $37{ }^{\circ} \mathrm{C}$, aerobically for 24 hours. Only, Campylobacter was incubated in microaerophilic atmosphere, at $42^{\circ} \mathrm{C}$ for 48 hours. The growth inhibition zones were measured after incubation of the isolates under their optimal growth conditions and were ranged between $6 \mathrm{~mm}$ and $30 \mathrm{~mm}$ in diameter. The antimicrobial activity was determined according to the diameters of the inhibition zones $(0-14 \mathrm{~mm}$ resistant $(\mathrm{R})$, 14-19 mm moderate susceptible (M) and 19-30 mm susceptible microorganisms $(\mathrm{S}))$.

\section{Broth dilution method}

This method was used in order to determine minimal inhibitory concentration (MIC) of the particular essential oil that had revealed antimicrobial activity by disc diffusion method. For that purposes, $25 \mu \mathrm{l}$ of those essential oils $(50 \%$ solution of essential oil in DMSO $=500 \mu \mathrm{l} / \mathrm{ml})$ were diluted in equal quantities of $0.9 \%$ sodium chloride solution, to make them with concentration of $25 \%(250 \mu \mathrm{l} / \mathrm{ml})$. This concentration was decreased five times, subsequently, by adding $25 \mu \mathrm{l}$ of each bacterial or fungal suspension, thus the final concentrations were: $12.5 \%, 6.2 \%, 3.1 \%, 1.5 \%$ and $0.7 \%$ or $125 \mu \mathrm{l} / \mathrm{ml}, 62 \mu \mathrm{l} / \mathrm{ml}, 31 \mu \mathrm{l} / \mathrm{ml}, 15 \mu \mathrm{l} / \mathrm{ml}$ and $7 \mu \mathrm{l} / \mathrm{ml}$, respectively. $15 \mu \mathrm{l}$ of each bacterial or fungal suspensions with these particular concentrations were inoculated on solid media (Miller-Hinton agar, blood agar, Sabouraund agar), depending on the type of microorganism. The growth of any microorganism was evaluated after its incubation under the optimal growth conditions. The lowest concentration of essential oil which was able to inhibit the growth of the particular microorganism was considered as its minimal inhibitory concentration (MIC).

\section{Results and discusion}

\section{The chemical composition of essential oils}

The chemical composition of the essential oils was analyzed by GC/FID/MS and 93 components in total were identified, representing 89.7-96.5\% of the oils (Table 2). Among different classes of terpenes present in the berries oil isolated from samples from Valandovo, the monoterpene hydrocarbons $(\mathrm{MH})$ and the oxygen-containing sesquiterpenes (OS) were the major fractions with total participation of $47.2 \%$ and $26.8 \%$, respectively. The mass part of sesquiterpene hydrocarbons $(\mathrm{SH})$ and oxygen containing monoterpenes (OM) were $19.7 \%$ and $0.7 \%$, respectively (Table 2). The major components of the essential oil were limonene (24.9\%), $\alpha$-pinene (19.2\%) and cedrol (23.1\%). 
Table 2. Chemical composition (\%) of leaves (LEO) and berries (BEO) essential oils of Juniperus foetidissima from R. Macedonia

\begin{tabular}{|c|c|c|c|c|c|c|c|c|}
\hline No. & Components & RI & RIE & Val-BEO & Val-LEO & U-LEO & Ve-LEO & Oh-LEO \\
\hline 1 & Tricyclene & 921 & 930.4 & $\operatorname{tr}$ & 0.1 & $\operatorname{tr}$ & $\operatorname{tr}$ & - \\
\hline 2 & $\alpha$-Thujene & 931 & 933.8 & - & - & - & - & $\operatorname{tr}$ \\
\hline 3 & $\alpha$-Pinene & 932 & 937.2 & 19.2 & 67.6 & 9.6 & 14.7 & - \\
\hline 4 & Camphene & 946 & 945.5 & 0.6 & 1.0 & 0.5 & 0.2 & 1.3 \\
\hline 5 & Sabinene & 969 & 962.8 & $\operatorname{tr}$ & - & - & - & 1.5 \\
\hline 6 & $\beta$-Pinene & 974 & 964.1 & 0.4 & 1.4 & 02 & 0.1 & - \\
\hline 7 & $\beta$-Myrcene & 988 & 976.4 & 1.1 & 1.9 & 0.7 & 0.6 & 0.2 \\
\hline 8 & $\Delta^{3}$-Carene & 1008 & 989.8 & - & 0.4 & - & 3.4 & - \\
\hline 9 & $p$-Cymene & 1020 & 1001.8 & 0.2 & 0.3 & 0.3 & 0.2 & - \\
\hline 10 & Limonene & 1024 & 1006.7 & 24.9 & 10.0 & 27.1 & 17.9 & 0.8 \\
\hline 11 & $\gamma$-Terpinene & 1054 & 1033.4 & 0.3 & 0.5 & 0.2 & 0.1 & 1.3 \\
\hline 12 & $\alpha$-Terpinolene & 1086 & 1062.5 & 0.4 & 0.7 & 0.3 & 0.6 & 0.8 \\
\hline 13 & Linalool & 1095 & 1077.0 & - & - & - & - & 0.4 \\
\hline 14 & cis-Thujone & 1101 & 1079.2 & - & - & - & - & 8.3 \\
\hline 15 & trans-Thujone & 1112 & 1090.9 & - & - & - & - & 2.6 \\
\hline 16 & trans-Pinocarveol & 1135 & 1117.1 & - & - & - & - & - \\
\hline 17 & Camphor & 1141 & 1123.7 & 0.1 & 0.2 & 0.1 & 0.2 & - \\
\hline 18 & Borneol & 1165 & 1150.0 & $\operatorname{tr}$ & 0.1 & $\operatorname{tr}$ & - & - \\
\hline 19 & cis-Pinocamphone & 1172 & 1157.4 & - & - & $\operatorname{tr}$ & - & - \\
\hline 20 & Terpinen-4-ol & 1174 & 1161.8 & 0.1 & - & 0.1 & 0.1 & 19.1 \\
\hline 21 & p-Cymene-8-ol & 1179 & 1171.1 & - & - & 0.3 & - & - \\
\hline 22 & $\alpha$-Terpineol & 1186 & 1175.1 & - & - & $\operatorname{tr}$ & - & 0.5 \\
\hline 23 & Myrtenal & 1195 & 1176.8 & - & - & - & - & - \\
\hline 24 & cis-Piperitol & 1195 & 1177.7 & - & - & - & - & 0.6 \\
\hline 25 & Verbenone & 1204 & 1187.4 & - & 0.1 & - & 0.1 & - \\
\hline 26 & trans-Piperitol & 1207 & 1187.4 & - & - & $\operatorname{tr}$ & - & 0.4 \\
\hline 27 & Fenchyl acetate & 1218 & 1194.6 & 0.2 & 0.1 & 0.4 & 0.2 & - \\
\hline 28 & cis-Mentha-1(7),8-dien-2-ol & 1227 & 1200.9 & - & - & 0.4 & - & - \\
\hline 29 & Carvone & 1239 & 1218.8 & - & - & 0.4 & - & - \\
\hline 30 & Carvacrol methyl ether & 1241 & 1219.6 & - & - & - & - & - \\
\hline 31 & Linalool oxide acetate & 1287 & 1263.4 & 0.1 & - & 0.1 & 0.1 & 0.4 \\
\hline 32 & trans-Sabinyl acetate & 1289 & 1268.5 & - & - & - & - & 2.1 \\
\hline 33 & 2E,4Z-Decadienal & 1292 & 1269.2 & - & - & 0.1 & 0.1 & - \\
\hline 34 & 2E, 4E-Decadienol & 1319 & 1287.8 & - & - & 2.3 & 2.9 & - \\
\hline 35 & Dihydrocarveol acetate & 1326 & 1297.3 & - & - & 0.4 & - & - \\
\hline 36 & $\delta$-Elemene & 1335 & 1306.0 & - & - & 0.1 & 0.3 & 0.1 \\
\hline 37 & $\alpha$-Cubebene & 1345 & 1318.6 & 0.2 & - & 0.1 & 0.2 & 0.1 \\
\hline 38 & $\alpha$-Copaene & 1374 & 1345.4 & 0.3 & $\operatorname{tr}$ & 0.1 & 0.2 & 3.7 \\
\hline 39 & $\beta$-Bourbonene & 1387 & 1354.5 & 0.1 & - & 0.1 & 0.1 & 0.1 \\
\hline 40 & 7-epi-Sesquithujene & 1390 & 1359.7 & - & - & 0.2 & 0.2 & - \\
\hline 41 & $\beta$-Elemene & 1389 & 1362.2 & - & - & - & - & 0.7 \\
\hline 42 & Sesquithujene & 1405 & 1374.1 & 0.1 & $\operatorname{tr}$ & 0.1 & 0.1 & - \\
\hline 43 & $\beta$-Funebrene & 1413 & 1381.3 & 3.3 & - & 4.3 & 3.9 & - \\
\hline 44 & trans-Caryophyllene & 1418 & 1386.9 & 1.8 & $\operatorname{tr}$ & $\operatorname{tr}$ & - & 1.8 \\
\hline 45 & $\beta$-Cedrene & 1419 & 1387.7 & $\operatorname{tr}$ & 0.5 & 2.7 & 2.0 & - \\
\hline 46 & $\beta$-Copaene & 1430 & 1396.1 & - & - & - & - & 0.6 \\
\hline 47 & cis-Thujopsene & 1430 & 1397.4 & 0.7 & 0.2 & 0.8 & 0.7 & - \\
\hline 48 & $\gamma$-Elemene & 1434 & 1399.7 & - & - & - & - & 1.6 \\
\hline 49 & $\alpha$-Guaiene & 1437 & 1405.3 & 0.1 & - & - & 0.1 & 0.1 \\
\hline 50 & Aromadendrene & 1439 & 1412.1 & $\operatorname{tr}$ & - & - & - & 0.5 \\
\hline
\end{tabular}




\begin{tabular}{|c|c|c|c|c|c|c|c|c|}
\hline No. & Components & RI & RIE & Val-BEO & Val-LEO & U-LEO & Ve-LEO & Oh-LEO \\
\hline 51 & trans-Muurola-3,5-dien & 1451 & 1418.2 & 0.5 & $\operatorname{tr}$ & 0.2 & 0.2 & 0.2 \\
\hline 52 & $\alpha$-Humulene & 1452 & 1421.8 & 0.9 & 0.2 & $\operatorname{tr}$ & $\operatorname{tr}$ & 1.4 \\
\hline 53 & $\beta$-Farnesene & 1454 & 1422.5 & $\operatorname{tr}$ & - & 0.8 & 0.7 & - \\
\hline 54 & $\alpha$-Acoradiene & 1464 & 1434.4 & 0.3 & 0.1 & 0.4 & 0.3 & - \\
\hline 55 & 10-epi- $\beta$-Acoradiene & 1474 & 1434.4 & 0.3 & 0.1 & 0.4 & 0.4 & - \\
\hline 56 & trans-Cadina-1(6),4-diene & 1475 & 1441.3 & 1.0 & - & 0.6 & 0.6 & 0.2 \\
\hline 57 & $\gamma$-Muurolene & 1478 & 1444.6 & 0.3 & 0.2 & - & - & 0.62 \\
\hline 58 & Germacrene D & 1484 & 1449.9 & 1.5 & 0.2 & 0.5 & 0.4 & 11.0 \\
\hline 59 & $\alpha$-Muurolene & 1500 & 1468.3 & 1.8 & - & - & - & 2.2 \\
\hline 60 & $\beta$-Himachalene & 1500 & 1467.8 & - & 0.1 & 0.3 & 0.3 & - \\
\hline 61 & Cuprenene & 1505 & 1474.2 & 0.3 & 0.1 & 0.5 & 0.4 & 0.2 \\
\hline 62 & $\alpha$-Alaskene & 1512 & 1480.0 & 0.8 & 0.3 & 1.0 & 1.1 & - \\
\hline 63 & $\gamma$-Cadinene & 1513 & 1482.1 & 0.8 & - & - & - & 1.4 \\
\hline 64 & $\delta$-Cadinene & 1522 & 1490.3 & 2.9 & 0.2 & 1.5 & 1.2 & 6.3 \\
\hline 65 & trans-Cadina-1,4-diene & 1533 & 1538.8 & 0.6 & - & 0.4 & 0.5 & 0.2 \\
\hline 66 & $\alpha$-Cadinene & 1537 & 1504.1 & 0.1 & - & - & - & 0.6 \\
\hline 67 & Hedycariol & 1546 & 1556.0 & - & - & - & - & 0.1 \\
\hline 68 & Germacrene B & 1559 & 1525.6 & - & - & - & - & 1.1 \\
\hline 69 & $\beta$-Calacorene & 1564 & 1530.5 & 0.1 & - & 0.2 & - & - \\
\hline 70 & Germacrene D-4-ol & 1574 & 1542.9 & - & - & $\operatorname{tr}$ & - & 1.1 \\
\hline 71 & Caryophyllene oxide & 1581 & 1552.6 & 0.2 & 0.4 & 0.2 & 0.1 & 0.2 \\
\hline 72 & allo-Cedrol & 1589 & 1560.1 & 1.7 & - & 1.9 & 2.2 & - \\
\hline 73 & Cedrol & 1600 & 1576.2 & 23.1 & 9.6 & 28.8 & 33.9 & - \\
\hline 74 & $\beta$-Oplopenone & 1607 & 1577.8 & - & - & - & - & 0.9 \\
\hline 75 & 1,10-di-epi-Cubenol & 1618 & 1582.8 & - & - & - & - & 0.1 \\
\hline 76 & 1-epi-Cubenol & 1627 & 1595.2 & 1.3 & 0.1 & 0.7 & 0.8 & 0.2 \\
\hline 77 & $\alpha$-Acorenol & 1632 & 1601.7 & 0.2 & - & 0.2 & 0.3 & - \\
\hline 78 & 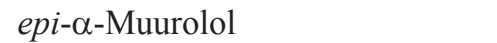 & 1640 & 1609.7 & 0.4 & - & 0.2 & - & 2.1 \\
\hline 79 & $\alpha$-Muurolol & 1645 & 1613.4 & 0.1 & - & 0.1 & 0.4 & 0.5 \\
\hline 80 & $\alpha$-Cadinol & 1653 & 1621.9 & 0.2 & - & 2.1 & 0.2 & 3.4 \\
\hline 81 & $\beta$-Atlantone & 1668 & 1629.4 & - & - & 0.2 & - & - \\
\hline 82 & iso-Cedranol & 1672 & 1648.9 & - & - & 0.2 & - & - \\
\hline 83 & 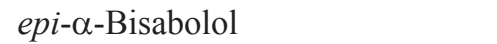 & 1683 & 1650.2 & - & - & 0.1 & - & - \\
\hline 84 & cis-14-nor-Muurol-5-en-4-one & 1688 & 1655.2 & 0.1 & - & 0.1 & - & 0.2 \\
\hline 85 & Cedryl acetate & 1767 & 1732.8 & 0.1 & - & 0.1 & 0.1 & - \\
\hline 86 & Sandarocopimara-8(14),15-diene & 1968 & 1933.5 & - & - & - & - & 0.3 \\
\hline 87 & Manool oxide & 1987 & 1962.4 & 0.1 & - & $\operatorname{tr}$ & 0.1 & 2.0 \\
\hline 88 & Abieta-8,12-diene & 2022 & 1989.0 & - & - & - & - & $\operatorname{tr}$ \\
\hline 89 & Abietatriene & 2054 & 2024.7 & $\operatorname{tr}$ & - & $\operatorname{tr}$ & - & 0.2 \\
\hline 90 & Abietadiene & 2080 & 2051.9 & 0.1 & 0.1 & $\operatorname{tr}$ & 0.1 & 1.2 \\
\hline 91 & Abieta-8(14),13(15)-diene & 2135 & 2118.9 & 0.1 & - & - & - & 0.1 \\
\hline 92 & Sandaracopimarinal & 2184 & 2157.3 & - & - & - & - & 0.2 \\
\hline 93 & 4-epi-Abietal & 2298 & 2264.5 & 0.1 & - & 0.1 & 0.1 & 1.6 \\
\hline \multicolumn{4}{|c|}{ Total (\%) } & 95.3 & 96.5 & 93.2 & 93.2 & 89.7 \\
\hline \multicolumn{4}{|c|}{ Monoterpene hydrocarbons (MH) } & 47.2 & 83.2 & 38.2 & 38.9 & 6.0 \\
\hline \multicolumn{4}{|c|}{ Oxygen containing monoterpenes (OM) } & 0.7 & 0.5 & 1.7 & 0.6 & 34.8 \\
\hline \multicolumn{4}{|c|}{ Sesquiterpene hydrocarbons (SH) } & 19.7 & 2.3 & 15.4 & 13.7 & 34.6 \\
\hline \multicolumn{4}{|c|}{ Oxygen containing sesquiterpenes (OS) } & 26.8 & 10.1 & 34.7 & 37.9 & 8.8 \\
\hline \multicolumn{4}{|c|}{ Diterpenes (D) } & 0.5 & 0.1 & 0.1 & 0.1 & 5.5 \\
\hline \multicolumn{4}{|c|}{ Non-terpene components (NT) } & 0.4 & 0.3 & 3.1 & 3.1 & 0.1 \\
\hline
\end{tabular}

RI - Retention index - literature data (Adams, 2007); RIE - Retention index experimentally determined with reference to a homologous series of $n$-alkanes on an HP-5ms column (AMDIS); (-) - not found, tr - traces $<0.05$; 
The composition of leaves essential oil was variable depending on the geographical origin. In Val-LEO the $\mathrm{MH}$ was the major fraction $(83.7 \%)$, followed by smaller fraction of OS $(10.1 \%)$. The predominant components in this oil were: $\alpha$-pinene $(67.6 \%)$, limonene $(10.0 \%)$ and cedrol (9.6\%). Ve-LEO and U-LEO were characterized by limonene $(17.9 \%$ and $27.1 \%)$, $\alpha$-pinene $(14.7 \%$ and $9.6 \%)$ and cedrol (33.9\% and $28.8 \%$, respectively). These oils were characterized by almost equal amounts of $\mathrm{MH}(38.9$ and $38.2 \%$ ) and OS (34.7 and $37.9 \%$, respectively) (Table 1). On the other hand, Oh-LEO contained mainly $\mathrm{SH}$ $(34.6 \%)$ and $\mathrm{OM}(34.8 \%)$. The major components of this oil were completely different from previous oils. Terpinen4-ol (19.1\%), cis-thujone (8.3\%), germacrene D (11.0\%), $\delta$-cadinene $(6.3 \%)$ and $\alpha$-cadinol $(3.4 \%)$ were predominant constituents (Table 2). On the other hand, $\alpha$-pinene, limonene and cedrol were not identified or were present in amounts $<0.1 \%$. This oil contain larger amounts of diterpenes $(5.5 \%)$, mainly with abietane skeleton such as abietadiene, abietal, abieta-1,12-dine, abieta-8(14),13(15)dine, abietatriene and sandaracopimarinal. Val-LEO and Ve-LEO contained some of the mentioned diterpenes in amounts $<0.1 \%$ or in traces.

Comparing to literature data, similarities and differences could be noticed. Adams found sabinene (19.6\%), $\alpha$-thujone (18.6\%), terpinen-4-ol (17.6\%) and $\gamma$-terpinene (6.5\%) being the major components of the leaf essential oil of $J$. foetidissima collected in Greece (Adams, 1990). At the same time, the minor compounds of this essential oil were $\alpha$-terpinene (4.3\%), $\beta$-thujone (3.5\%), cedrol (3.2\%), myrcene $(2.7 \%)$ and $\alpha$-pinene $(2.6 \%)$. According to the Iranian researchers, the major components of the essential oils of fruits, leaves of male and leaves of female plant of $J$. foetidissima were sabinene (37.1, 19.9 and 16.8\%), $\alpha$-pinene $(29.9,22.2$ and 18.6\%) and limonene (11.8, 20.9 and $13.6 \%$ ), respectively (Asili et al., 2010). Tunalier et al. found $\beta$-thujone and cedrol as predominant components of the essential oil of leaf and sabinene as major component in the berry essential oil of $J$. foetidissima from Turkey (Tunalier et al., 2002). Considering essential oil composition of J. foetidissima from Balkans, only one article was published. Lesjak et al. examined one sample from region of Prespa Lake from RM and found sabinene (39.9\%), $\gamma$-terpinene (10.1\%) and terpinen-4-ol (17.0\%) as major monoterpenes and germacrene D $(0.7 \%)$ and $\gamma$-cadinene $(2.9 \%)$ as major sesquiterpene (Lesjak et al., 2013). Although the mentioned region of collection was geographically close to Ohrid Lake, where our samples were collected, the leaves oil composition differed mainly in the percentage amounts of trans-thujone $(2.6 \%)$ and cis-thujone $(8.3 \%)$ that were present in our oil samples, but were not identified by Lesjak et al.

\section{Antimicrobial activity of essential oils}

Antimicrobial screening of the essential oils of Macedonian J. foetidissima was made by disc diffusion and broth dilution method against 16 bacterial isolates of Gram positive and Gram negative bacteria and one strain of Candida albicans. The results obtained showed weak antimicrobial activity of both leaves and berries essential oils. The sensitive bacteria to antimicrobial effects of leaves essential oils were Staphylococcus aureus, Streptococcus pyogenes and Haemophilus influenzae $(\mathrm{MIC}=125 \mu \mathrm{l} / \mathrm{ml})$. The berry essential oil showed moderate activity against Streptococcus pyogenes and Haemophilus influenzae (MIC > $500 \mu \mathrm{l} / \mathrm{ml}$ ). Both leaves and berries essential oils showed moderate antimicrobial activity against Campylobacter jejuni (MIC > $500 \mu \mathrm{l} / \mathrm{ml}$ ). Other investigated bacterial strains and Candida albicans were completely resistant to the antimicrobial effects of $J$. foetidissima essential oils (Table 3 ).

Antimicrobial activity of Juniperus essential oils was previously investigated and literature data pointed out wide range of activity from no antimicrobial effects to some antimicrobial activity against various tested microbial strains. Juniper essential oil obtained from the juniper berry (J. communis) have shown bactericidal activities against Gram-positive and Gram-negative bacteria species, with MIC values between 8 and 70\% (V/V), as well as a strong fungicidal activity against yeasts, yeastlike fungi and dermatophytes, with MIC values below $10 \%(\mathrm{~V} / \mathrm{V})$. The strongest fungicidal activity was recorded against Candida spp. (MIC from 0.78 to $2 \%, \mathrm{~V} / \mathrm{V}$ ) and dermatophytes (from 0.39 to $2 \%, \mathrm{~V} / \mathrm{V}$ ). GC/MS analysis of this essential oil showed that the main compounds in the oil were $\alpha$-pinene $(29.17 \%)$ and $\beta$-pinene (17.84\%), sabinene $(13.55 \%)$, limonene $(5.52 \%)$, and myrcene $(0.33 \%)$ (Pepelnjak et al., 2005). The essential oil of J. communis growing wild in Kosovo, showed moderate to high activity against Staphylococcus aureus, Escherichia coli and Hafnia alvei. Pseudomonas aeruginosa was resistant to this essential oil (Haziri et al., 2013). Furthermore, J. excelsa essential oil have shown strong activity against anaerobic bacteria Clostridium perfringens and moderate activity against Staphylococcus aureus, Streptococcus pyogenes, Streptococcus pneumonia, Mycobacterium smegmatis, Candida albicans and Candida krusei (Inlu et al., 2008). Besides moderate to no activity against Candida, berry essential oil of $J$. excelsa have shown strong antifungal activity toward 10 strains of pathogenic fungi. In this way, authors suggested that this essential oil can be used in production of food as natural preservative of fungal contamination. Additionally, $\alpha$-pinene has been considered as antimicrobial active component responsible for the activity of $J$. excelsa essential oils (Sokovic et al., 2004). The antimicrobial activity of essential oil of $J$. phoenicea from Algeria was tested on nine bacterial strains. Variable degree of antimicrobial activity was achieved (Ramadani et al., 2013) and again, the activity was probably due to the high amount of $\alpha$-pinene in the oil. Angioni et al. tested the essential oils of $J$. oxycedrus, J. phoenicea and J. communis against Candida albicans, Staphylococcus aureus, Escherichia coli and Pseudomonas aeruginosa. The results ob- 
Table 3. Antimicrobial activity of essential oils of J. foetidissima

\begin{tabular}{|c|c|c|c|c|}
\hline Microorganism & & Val-BEO & Val-LEO & Oh-LEO \\
\hline \multirow{2}{*}{ Streptococcus pneumoniae } & DD & $\mathrm{R}$ & $\mathrm{R}$ & $\mathrm{R}$ \\
\hline & MIC & n.m. & n.m. & n.m. \\
\hline \multirow{2}{*}{ Staphylococcus aureus } & $\mathrm{DD}$ & $\mathrm{R}$ & $\mathrm{S}$ & $\mathrm{S}$ \\
\hline & MIC & n.m. & 125 & 125 \\
\hline \multirow{2}{*}{ Staphylococcus epidermidis } & $\mathrm{DD}$ & $\mathrm{R}$ & $\mathrm{R}$ & $\mathrm{R}$ \\
\hline & MIC & n.m. & n.m. & n.m. \\
\hline \multirow{2}{*}{ Streptococcus agalactiae } & $\mathrm{DD}$ & $\mathrm{R}$ & $\mathrm{R}$ & $\mathrm{R}$ \\
\hline & MIC & n.m. & n.m. & n.m. \\
\hline \multirow{2}{*}{ Streptococcus pyogenes } & $\mathrm{DD}$ & $\mathrm{M}$ & $\mathrm{S}$ & M \\
\hline & MIC & $>500$ & 125 & $>500$ \\
\hline \multirow{2}{*}{ Enterococcus } & $\mathrm{DD}$ & $\mathrm{R}$ & $\mathrm{R}$ & M \\
\hline & MIC & n.m. & n.m. & $>500$ \\
\hline \multirow{2}{*}{ Corynebacterium spp. } & $\mathrm{DD}$ & $\mathrm{R}$ & $\mathrm{R}$ & $\mathrm{R}$ \\
\hline & MIC & n.m. & n.m. & n.m. \\
\hline \multirow{2}{*}{ Haemophilus influenzae } & $\mathrm{DD}$ & M & $\mathrm{S}$ & $\mathrm{S}$ \\
\hline & MIC & $>500$ & 125 & 125 \\
\hline \multirow{2}{*}{ Acinetobacter spp. } & $\mathrm{DD}$ & $\mathrm{R}$ & $\mathrm{R}$ & $\mathrm{R}$ \\
\hline & MIC & n.m. & n.m. & n.m. \\
\hline \multirow{2}{*}{ Escherichia coli } & $\mathrm{DD}$ & $\mathrm{R}$ & $\mathrm{R}$ & $\mathrm{R}$ \\
\hline & MIC & n.m. & n.m. & n.m. \\
\hline \multirow{2}{*}{ Salmonella enteritidis } & $\mathrm{DD}$ & $\mathrm{R}$ & $\mathrm{R}$ & $\mathrm{R}$ \\
\hline & MIC & n.m. & n.m. & n.m. \\
\hline \multirow{2}{*}{ Shigella flexneri } & $\mathrm{DD}$ & $\mathrm{R}$ & $\mathrm{R}$ & $\mathrm{R}$ \\
\hline & MIC & n.m. & n.m. & n.m. \\
\hline \multirow{2}{*}{ Campylobacter jejuni } & $\mathrm{DD}$ & $\mathrm{M}$ & M & $\mathrm{R}$ \\
\hline & MIC & $>500$ & $>500$ & n.m. \\
\hline \multirow{2}{*}{ Klebsiella pneumoniae } & $\mathrm{DD}$ & $\mathrm{R}$ & $\mathrm{R}$ & $\mathrm{R}$ \\
\hline & MIC & n.m. & n.m. & n.m. \\
\hline \multirow{2}{*}{ Pseudomonas aeruginosa } & $\mathrm{DD}$ & $\mathrm{R}$ & $\mathrm{R}$ & $\mathrm{R}$ \\
\hline & MIC & n.m. & n.m. & n.m. \\
\hline \multirow{2}{*}{ Proteus mirabilis } & $\mathrm{DD}$ & $\mathrm{R}$ & $\mathrm{R}$ & $\mathrm{R}$ \\
\hline & MIC & n.m. & n.m. & n.m. \\
\hline \multirow{2}{*}{ Candida albicans } & $\mathrm{DD}$ & $\mathrm{R}$ & $\mathrm{R}$ & $\mathrm{R}$ \\
\hline & MIC & n.m. & n.m. & n.m. \\
\hline
\end{tabular}

DD - disc diffusion (zone of inhibition including the diameter of disc $6 \mathrm{~mm}, \mathrm{R}$ - resistant with zone of inhibition 0-14 mm, M - moderate susceptible with zone of inhibition 14-19 mm and S - susceptible microorganism with zone of inhibition 19-30 mm); MIC - minimum inhibitory concentration ( $\mu 1 / \mathrm{ml})$; $\mathrm{n} . \mathrm{m}$. - not measured.

tained led to a non-significant inhibitory effect, although essential oil of $J$. phoenicea and $J$. oxycedrus exhibited rather good or weak activity against Candida albicans and Staphylococcus aureus (Angioni et al., 2003).

The study of the antimicrobial activity of leaf essential oil of $J$. oxycedrus from Tunisia showed that Escherichia coli was extremely resistant to this oil while Staphylococcus aureus was the most sensitive strain with MIC ranged from 600 to $650 \mu \mathrm{g} / \mathrm{ml}$ (Medini et al., 2010). Regarding antifungal activity, $J$. oxycedrus leaf essential oil provided to be an emergent alternative as antifungal agent against dermatophyte strains. Delta-3-carene was shown to be a fundamental compound for this activity (Cavaleiro et al., 2006). The evaluation of the biological activity of berry essential oil of Iranian $J$. foetidissima showed no antimicrobial activity against Candida albicans, Escherichia coli and Pseudomonas aeruginosa. The leaf essential oil of the same plant showed moderate activity against Bacillus subtilis, Candida albicans, Escherichia coli, Pseudomonas aeruginosa (MIC values between 3.125 and $6.25 \mathrm{mg} / \mathrm{ml}$ ) and Staphylococcus aureus (MIC $=25 \mathrm{mg} / \mathrm{ml}$ ) (Asili et al., 2010).

In general, Juniperus essential oils (J. communis, J. excelsa, J. phoenicea, J. oxycedrus and J. foetidissima) have 
shown stronger antimicrobial activity against Staphylococcus aureus and Candida albicans, rarely against other bacterial or fungal strains. Only few authors found susceptible antimicrobial activity against Escherichia coli, Streptococcus pyogenes and Streptococcus pneumonia. Comparing to our findings, leaves essential oil of Macedonian J. foetidissima showed similar antimicrobial activity against Staphylococcus aureus and Streptococcus pyogenes. Promising antimicrobial activity of leaves essential oil against Haemophilus influenzae was found for the first time. It is worth to mention that besides good antifungal activity presented in the literature (Asili et al., 2010; Haziri et al., 2013; Unlu et al., 2008), essential oils from Macedonian J. foetidissi$m a$ have shown no activity against Candida albicans.

\section{Conclusion}

The berries essential oil of Macedonian $J$. foetidissi$m a$ was characterized by large amount of monoterpene hydrocarbons (MH) $(47.2 \%)$ and smaller amounts of oxygen-containing sesquiterpenes (OS) (26.8\%), with: limonene $(24.9 \%), \alpha$-pinene $(19.2 \%)$ and cedrol $(23.1 \%)$ as predominant constituents. The composition of leaves essential oil was variable depending on the geographical origin. In the oil obtained from samples from south-eastern part of RM, the major fraction was MH (83.7\%), followed by smaller fraction of OS $(10.1 \%)$. The predominant components were: $\alpha$-pinene $(67.6 \%)$, limonene $(10.0 \%)$ and cedrol $(9.6 \%)$. In the essential oils obtained from samples originated from central part of RM the predominant components were also limonene $(17.9 \%$ and $27.1 \%), \alpha$-pinene $(14.7 \%$ and $9.6 \%)$ and cedrol $(33.9 \%$ and $28.8 \%)$ respectively. These oils were characterized by almost equal amounts of MH (38.9 and 38.2\%) and OS (34.7 and 37.9\%, respectively). On the other hand, the essential oil obtained from samples originated from south-western part of RM, contained mainly SH (34.6\%) and OM (34.8\%) and the major components of this oil were completely different from previous oils. Those were: terpinen-4-ol (19.1\%), cis-thujone $(8.3 \%)$, germacrene $\mathrm{D}(11.0 \%), \delta$-cadinene $(6.3 \%)$ and $\alpha$-cadinol (3.4\%). This oil contain larger amounts of diterpenes $(5.5 \%)$, mainly with abietane skeleton such as abietadiene, abietal, abieta-1,12-dine, abieta-8(14),13(15)-dine, abietatriene and sandaracopimarinal. The both types of essential oils possessed low capacity for antimicrobial activity. Bacteria sensitive to the antimicrobial effects of leaves essential oils were: Staphylococcus aureus, Streptococcus pyogenes and Haemophilus influenzae $(\mathrm{MIC}=125 \mu \mathrm{l} / \mathrm{ml})$. The berry essential oil showed moderate activity against Streptococcus pyogenes and Haemophilus influenzae (MIC $>500 \mu \mathrm{l} / \mathrm{ml}$ ). Both leaves and berries essential oils showed moderate antimicrobial activity against Campylobacter jejuni $(\mathrm{MIC}>500 \mu \mathrm{l} / \mathrm{ml})$. Other investigated bacterial strains and Candida albicans were completely resistant to the antimicrobial effects of $J$. foetidissima essential oils.

\section{Acknowledgements}

The Ministry of Education and Science of Republic of Macedonia (project No.13-3582/1) supported this research work.

\section{References}

Adams, R., 1987. Investigation of Juniperus Species of the United States for New Sources of Cedarwood Oill. Econ. Bot. $41,48-54$.

Adams, R., 1990. Variation in the chemical composition of the leaf oil of Juniperus foetidissima Willd. J. Essent. Oil Res. 2, 67-70.

Adams, R., 2007. Identification of Essential Oil Components by Gas Chromatography/Mass Spectrometry, 4th Ed., Allured Publishing Corporation, IL, USA, 9-31.

Angioni, A., Barra, A., Russo, M.T., Coroneo, V., Dessi, S., Cabras, P., 2003. Chemical composition of the essential oils of Juniperus from ripe and unripe berries and leaves and their antimicrobial activity. J. Agric. Food Chem. 51 (10), 3073-3078.

Asili, J., Emami, S.A., Rahimizadeh, M., Fazly-Bazzaz, B.S., Hassanzadeh, M.K., 2010. Chemical and antimicrobial studies of Juniperus sabina L. and Juniperus foetidissima Willd. essential oils. J. Essent. Oil Bear. Plants 13, 25-36.

Balaban, M., Atik, C., Ucar, G., 2003. Fungal growth inhibition by wood extracts from Juniperus foetidissima and J. oxycedrus. Holz als Roh und Werkstoff 61, 231-232.

Cavaleiro, C., Pinto, E., Gonçalves, M.J., Salgueiro, L., 2006. Antifungal activity of Juniperus essential oils against dermatophyte, Aspergillus and Candida strains. J. App. Microb. 100 (6), 1333-1338.

Emami, S.A., Asgary, S., Naderi, G.A., Shams Ardekani, M.R., Kasher, T., Aslani, S., Airin, A., Sahebkar, A., 2011. Antioxidant activities of Juniperus foetidissima essential oils against several oxidative systems. Rev. Brasil. Farmacog. 21, 627-634.

Emami, S.A., Asili, J., Mohagheghi, Z., Hassanzadeh, M.K., 2007. Antioxidant Activity of Leaves and Fruits of Iranian Conifers. Evid. Based Complement. Alternat. Med. 4, 313 319.

Haziri, A., Faiku, F., Mehmeti, A., Govori, S., Abazi, S., Daci, M., Haziri, I., Bytyqi-Damoni, A., Mele, A., 2013. Antimicrobial properties of the essential oil of Juniperus communis (L.) growing wild in east part of Kosovo. Am. J. Pharmacol. Toxicol. 8 (3), 128-133.

Lesjak, M.M., Beara, I.N., Orcic, D.Z., Ristic, J.D., Anackov, G.T., Bozin, B.N., Mimica-Dukic, N.M., 2013. Chemical characterisation and biological effects of Juniperus foetidissima Willd. 1806. Food Science \& Technology 53, 530-539.

Marcysiak, K., Mazur, M., Romo, A., Montserrat, J.M., Didikuh, Y., Baratynska, K., Jasinski, A., Kosinski, P., Boratynski, A., 2007. Numerical taxonomy of Juniperus thurifera, Juniperus excelsa and Juniperus foetidissima (Cupressaceae) based on morphological characters. Botanical Journal of the Linnean Society 155, 483-495.

Medini, H., Elaissi, A., Khauja, M.L., Charaief, I., Farhat, F., Hammami, M., Chemili, R., Harzallah-Skhiri, F., 2010. Leaf essential oil of Juniperus oxycedrus L. (Cupressaceae) harvested in northern Tunisia: composition and intra-specific variability. Chem. \& Biodiver. 7 (5), 1254-1266.

Micevski, K., 1998. Flora na Republika Makedonija. Makedons- 
kata akademija na naukite i umetnostite, Skopje, Republika Makedonija.

Orhan, N., Akkol, E., Ergun, F., 2012. Evaluation of anti-inflammatory and antinociceptive effects of some Juniperus species growing in Turkey. Turk. J. Biol. 36, 719-726.

Ozturk, M., Tumen, I., Ug'ur, S., Aydog, F., Topcu, G., 2010. Evaluation of fruit extractas of six Turkish Juniperus species for their antioxidant, anticholinesterase and antimicrobial activities. J. Sci. Food Agric. 91, 867-876.

Pepelnjak, S., Kosalec, I., Kalodzera, Z., Blazevic, N., 2005. Antimicrobial activity of juniper berry essential oil. Acta Pharm. 55, 417-422.

Ramadani, M., Lograda, T., Silini, H., Zeraib, A., Chalad, P., Figuerdo, G., Bouchaala, M., Zerrar, S., 2013. Antibacterial activity of the essential oil of Juniperus phoenicea from Eastern Algeria. J. App. Pharm. Sci. 3 (11), 22-28.

Sadaeghi-Aliabadi, H., Emami, A., Saidim Sadeghi, B., Jafarain, A., 2009. Evaluation of in vitro cytotoxic effects of Juniper- us foetidissima and Juniperus sabina extracts against a panel of cancer cells. Iran. J. Pharm. Res. 8, 281-286.

Sokovic, M., Ristic, M., Grubisic, A., 2004. Chemical composition and antifungal activity of the essential oil of Juniperus excelsa berries. Pharm. Biol. 42, 328-334.

Tayoub, G., Odeh, A., Ghanem, I., 2012. Chemical composition and efficacy of essential oil from Juniperus foetidissima Willd against the Kharpa Beetle. Int. J. Med. Arom. Plants 2, 501-508.

Tunalier, Z., Kirimer, N., Baser, K.H.C., 2002. The composition of essential oils from various parts of Juniperus foetidissima. Chem. Nat. Compd. 38, 43-47.

Tunalier, Z., Kirimer, N., Baser, K.H.C., 2004. A potential new source of Cedarwood oil: Juniperus foetidissima Willd. J. Essent. Oil Res. 16, 233-235.

Unlu, M., Vardar-Unlu, G., Vural, N., Domnez, E., Cakmak, O., 2008. Composition and antimicrobial activity of Juniperus excelsa essential oil. Chem. Nat. Compd. 44 (1), 129-131.

\title{
Резиме
}

\section{Антимикробна активност на етерично масло од бобинки и од игличи од македонскиот Juniperus foetidissima Willd. (Cupressaceae)}

\author{
Фљореша Сеља ${ }^{\mathrm{a}}$, Марија Карапанџова ${ }^{\mathrm{a}^{*}}$, Гоше Стефков ${ }^{\mathrm{a}}$, Ивана Цветковиќ ${ }^{\mathrm{a}}$,

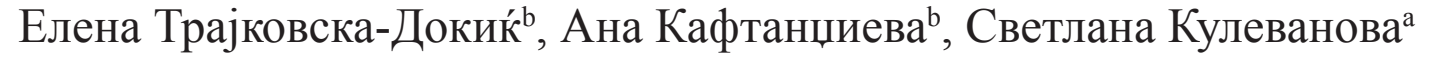

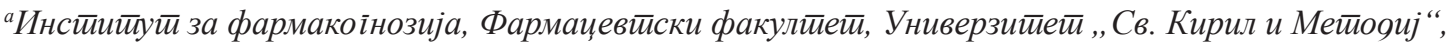
Мајка Тереза 47, 1000 Скойје, Р. Макеоонија

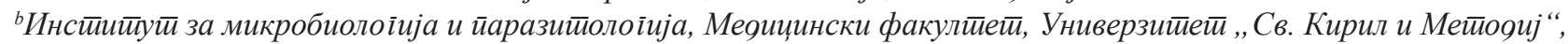
50-тиа Дивизија бр. 6, 1000 Скойје, Р. Макеоонија

Клучни зборови: Juniperus foetidissima, иглички, бобинки, етерично масло, GC/FID/MS состав, антимикробна активност

Хемискиот состав и антимикробната активност се испитувани кај етеричното масло од иглички и од бобинки од Juniperus foetidissima Willd. (Cupressaceae) кој расте на територија на P. Македонија. Co GC/FID/MS анализа се идентификувани 93 компоненти кои сочинуваат од 89,7 до 96,5\% од маслото. Доминантни компоненти во етеричното масло од бобинки се $\alpha$-пинен $(19,2 \%)$, лимонен $(24,9 \%)$ и цедрол $(23,1 \%)$, следени со пониска застапеност на $\beta$-фунебрен, trans-кариофилен, гермакрен D и $\delta$-кадинен. Составот на етеричното масло од иглички варира во зависност од локалитетот на собирање на растителниот материјал. Според тоа, примероците што потекнуваат од југоисточна Македонија содржат етерично масло со доминантни $\alpha$-пинен $(67,6 \%)$ и лимонен $(10,0 \%)$, од централна Македонија лимонен $(17,9-27,1 \%)$ и цедрол $(28,8-33,9 \%)$, додека примероците од југозападна Македонија содржат етерично масло со доминантни терпинен-4-ол (19,1\%), cis-тујон (8,3\%), гермакрен D $(11,0 \%)$ and $\delta$-кадинен $(6,3 \%)$. Антимикробната активност на етеричните масла е испитувана со агар дифузиона и со агар дилуциона метода кон 16 бактериски изолати на Грам позитивни и Грам негативни бактерии и еден изолат на габата Candida albicans. Етеричните масла од иглички покажаа подобра антимикробна активност кон Staphylococcus aureus, Streptococcus pyogenes и Haemophilus influenzae (МИК $=125 \mu \mathrm{l} / \mathrm{ml}$ ) и умерена активност кон Campylobacter jejuni (МИК > $500 \mu \mathrm{l} /$ $\mathrm{ml}$ ). Останатите испитувани бактерии и Candida albicans покажаа резистентност кон антимикробната активност на етерични масла од $J$. foetidissima. 



\title{
Transfer of pharmacopoeial liquid chromatography reversed- phase methods for determination of related compounds in diclofenac sodium and metamizole sodium from conventional to core-shell column
}

\author{
*Katerina Brezovska ${ }^{1}$, Gabriela Petrovska ${ }^{1}$, Jelena Acevska ${ }^{1}$, Natalija Nakov ${ }^{1}$, \\ Ana Poceva-Panovska ${ }^{1}$, Jasmina Tonic-Ribarska ${ }^{1}$, Maja Hadzieva ${ }^{2}$, Aneta Dimitrovska ${ }^{1}$ \\ ${ }^{I}$ Faculty of Pharmacy, University Ss. Cyril and Methodius, Skopje, Macedonia \\ ${ }^{2}$ Alkaloid AD, Skopje, 1000 Skopje, Republic of Macedonia
}

Received: January 2015; Accepted: April 2015

\begin{abstract}
Core-shell silica particles were developed as a new material for chromatographic stationary phases in order to provide fast and high efficiency separations of small and large molecules and complex samples, at pressures compatible with conventional HPLC equipment. The aim of our work was to show the applicability of the HPLC columns based on a core-shell technology for determination of related substances in diclofenac sodium and in metamizole sodium using the methods described in the corresponding monographs of the European pharmacopoeia. The obtained results have shown that the proposed methods can be successfully transferred on core shell column, with suitable adjustment of injection volume and flow rate. The advantage of using core-shell column is fast and highly efficient separation on conventional HPLC equipment with increased sensitivity of the method and high throughput of the analysis, providing enhanced lab productivity and reduced costs.
\end{abstract}

Key words: core-shell column, HPLC, diclofenac sodium, metamizole sodium

\section{Introduction}

Recent developments in liquid chromatography (LC) are focused in obtaining HPLC columns with higher efficiency and increased resolution in less analysis time. For that purpose, shorter columns packed with smaller particle size ( $3 \mu \mathrm{m}$ and sub- $2 \mu \mathrm{m})$ have been introduced in LC. The small particle diameter improves the separation kinetics and therefore efficiency, but at the expense of increased operating backpressure, requiring specially designed ultra high performance pumping and flow system (Brice et al., 2009; Naijun, Andrew, 2007). Core-shell silica particles were developed as a new material for chromatographic stationary phases in order to provide fast and high effi-

\footnotetext{
* kami@ff.ukim.edu.mk

tel. +38923126032 ; fax. +38923123054
}

ciency separations of small and large molecules and complex samples, at pressures compatible with conventional HPLC equipment (Guiochon, Gritti, 2011). The solid-core and the well defined porous outer layer provide shorter diffusion paths of the analytes into the stationary phase, which significantly influence the separation parameters of the core-shell columns compared with those in fully porous particles. This particle morphology reduces band broadening and therefore improves separation efficiency (Destefano et al., 2012). When analytes are eluted from the column in narrow chromatographic bands, or in other words in low volume peaks, the sensitivity of the analysis is increased as the solute mass is concentrated into a smaller volume (Pereira, 2012). The columns packed with core-shell particles have been employed in a wide range of applications for analysis and quality control (Kirkland et al., 2013; Ruta et al., 2012). Core-shell 
columns have been mostly used for reversed-phase HPLC, but core-shell particles have been also employed in hydrophilic interaction liquid chromatography (HILIC) and chiral separation (Destefano et al., 2008; Berger 2011; Wu, et al., 2013). These materials have shown superior performance for separating both small molecules (Song et al., 2009; Yang et al., 2011) and larger compounds such as peptides (Schuster et al., 2012) and proteins (Fekete et al., 2012). The benefits of transferring the HPLC methods from columns packed with fully porous silica particles to core-shell columns are in maintaining column performance and minimizing operating difficulties, providing significant time and cost savings (Hayes et al., 2014).

The aim of our work was to show the applicability of the HPLC columns based on a core-shell technology for determination of related substances in diclofenac sodium and in metamizole sodium using the methods described in European pharmacopoeia (Ph.Eur.). The Ph.Eur. monograph for Diclofenac Sodium 01/2008:1002 requires use of conventional end-capped octylsylil silica gel for chromatography $\mathrm{R}(5 \mu \mathrm{m})$ with isocratic elution for determination of related substances. This monograph has been recently updated to version 07/2014:1002, where the method requires use of conventional end-capped octadecylsilyl silica gel for chromatography $\mathrm{R}(5 \mu \mathrm{m})$. In the monograph for Metamizole sodium (01/2008:1346, Ph. Eur.), for determination of related substances, base deactivated octadecylsilyl silica gel for chromatography $\mathrm{R}(5 \mu \mathrm{m})$ is proposed as a stationary phase, while in recently updated monograph version 04/2014:1346 (Metamizole sodium monohydrate) the method has been changed to ultra high performance liquid chromatography, requiring the use of column packed with end-capped octadecylsilyl silica gel for chromatography R $(1.8 \mu \mathrm{m})$.

In our study we have applied the columns based on core-shell technology for determination of related substances of diclofenac sodium and metamizole sodium using the methods described in the Ph.Eur. monographs 01/2008:1002 and 01/2008:1346 respectively.

\section{Experimental}

\section{Chemicals and standards}

Diclofenac sodium, diclofenac impurity A, metamizole sodium and metamizole impurity A certified reference standards, were purchased from EDQM (Strasbourg, France). Phosphoric acid ( $85 \%$ ), sodium dihydrogen phosphate, (Ph.Eur., grade for analysis), potassium hydrogen phosphate dibasic (analytical grade) and triethylamine were purchased from Merck, Germany. Methanol (HPLC grade) and acetonitrile (HPLC grade) were purchased from Carlo Erba Reagents, France. Water R, was obtained with a TKA-LAB Reinstwasser system (Niederelbert, Germany).

\section{Chromatographic Conditions}

HPLC separation was performed on Agilent 1100 and Agilent 1200 LC Systems (used as a conventional HPLC with pressures up to $400 \mathrm{bar}$ ). ChemStation software, Version A.10.02 (for experiments conducted on Agilent 1100) and Version B.04.03 (for experiments conducted on Agilent 1200) was used for data acquisition and instrument control.

\section{Method for related substances in diclofenac sodium}

The separation was performed on Poroshell 120 EC C8 $50 \times 4.6 \mathrm{~mm}, 2.7 \mu \mathrm{m}$ (Agilent) using a mixture of 34 volumes of a solution containing $0.5 \mathrm{~g} / \mathrm{L}$ phosphoric acid and $0.8 \mathrm{~g} / \mathrm{L}$ sodium dihydrogen phosphate $\mathrm{R}$, adjusted to pH 2.5 with phosphoric acid R and 66 volumes of methanol $\mathrm{R}$ as a mobile phase. The column temperature was $25^{\circ} \mathrm{C}$. Flow rate was $1 \mathrm{~mL} / \mathrm{min}$. Injection volume was $3 \mu \mathrm{L}$. UV detection was performed at $254 \mathrm{~nm}$.

\section{System suitability solution for diclofenac sodium}

Reference solution $b$, containing diclofenac sodium $(5 \mu \mathrm{g} / \mathrm{mL})$ and diclofenac impurity A $(5 \mu \mathrm{g} / \mathrm{mL})$, prepared as described in Ph.Eur. monograph for Diclofenac Sodium 01/2008:1002 was used as system suitability solution.

\section{Method for related substances in metamizole sodium}

The separation was performed on Kinetex XB-C18, 50 $\mathrm{mm} \times 2.1 \mathrm{~mm}, 5 \mu \mathrm{m}$ (Phenomenex, Inc), using a mixture of 28 volumes of methanol $R$ and 72 volumes of a buffer solution containing 1000 volumes of a $6.0 \mathrm{~g} / \mathrm{L}$ solution of sodium dyhidrogen phosphate $\mathrm{R}$ and 1 volume of triethylamine $\mathrm{R}, \mathrm{pH} 7.0$ (adjusted with strong sodium hydroxide solution $\mathrm{R})$ as a mobile phase. The column temperature was $25^{\circ} \mathrm{C}$. Flow rate was $0.2 \mathrm{~mL} / \mathrm{min}$. Injection volume was $0.5 \mu \mathrm{L}$. UV detection was performed at $254 \mathrm{~nm}$.

\section{System suitability solution for metamizole sodium}

Reference solution e, containing metamizole sodium $(0.3 \mathrm{mg} / \mathrm{mL})$ and metamizole impurity A $(0.4 \mathrm{mg} / \mathrm{mL})$ prepared as described in Ph.Eur. monograph for Metamizole sodium 01/2008:1346 was used as system suitability solution.

\section{Results and Discussion}

Two methods described in European pharmacopoeia (method for determination of related substances in diclofenac sodium and method for determination of related substances in metamizole sodium) were transferred from the conventional fully porous column, to column based on core-shell technology. The suitability of the core-shell columns was evaluated by comparing the obtained results for system suitability parameters against the chromatogra- 
phic system requirements according to Ph.Eur. (2.2.46 Chromatographic separation techniques). This chapter also limits the extent to which the various parameters of a chromatographic test may be adjusted to satisfy the system suitability criteria without fundamentally modifying the methods. According to these requirements the injection volume may be decreased, provided detection and repeatability of the peak(s) to be determined are satisfactory and no increase is permitted, and the flow rate may be adjusted ( \pm 50 per cent). Regarding the column parameters there is no change of the identity of the substituent of the stationary phase permitted (e.g. no replacement of $\mathrm{C} 18$ by $\mathrm{C} 8$ ) and the particle size may be reduced maximum 50 per cent, but it cannot be increased. The length of the column and the internal diameter may be adjusted \pm 70 per cent and \pm 25 per cent respectively.

\section{Method for related substances in diclofenac sodium}

The method for determination of related substances in diclofenac sodium described in the Ph. Eur. monograph 01/2008:1002, was transferred from conventional end-capped octylsylil silica gel for chromatography $\mathrm{R}$ $(0.25 \mathrm{~m} \times 4.6 \mathrm{~mm} ; 5 \mu \mathrm{m})$ on core-shell column $(\mathrm{C} 8,50 \mathrm{~mm}$ x $4.6 \mathrm{~mm} ; 2.7 \mu \mathrm{m}$ ). All method modifications, except the column length, were within the limits of Ph.Eur. (2.2.46). Reducing the column internal diameter facilitates sensitivity improvements and shorter columns can often deliver the required resolution (Pereira, 2012). The reduction of column size results in reduction of column volume, which required scaling down the injection volume from $20 \mu \mathrm{L}$ to 5 $\mu \mathrm{L}$ and $3 \mu \mathrm{L}$ (Figure 1).

Satisfactory system suitability requirements of the transferred method were obtained with the injection volume of the sample of $5 \mu \mathrm{L}$ and $3 \mu \mathrm{L}$ in total analysis time of 5 minutes (1.6 times of the retention time of diclofenac, $\mathrm{Rt}=2.9 \mathrm{~min}$ ). The requirement in Ph.Eur monograph for Diclofenac sodium (01/2008:1002) for the resolution (Rs) between the peaks from diclofenac sodium and impurity A (at least 6.5) was fulfilled (Rs $=10.6$ for volume of injection $5 \mu \mathrm{L}$ and Rs $=12.2$ for volume of injection $3 \mu \mathrm{L}$ ). The obtained values from system suitability tests (Table 1) for number of theoretical plates $(\mathrm{N})$, retention factor $(\mathrm{k}$ '), resolution (Rs), symmetry factor (As) and relative standard deviation (RSD \%), indicate on a satisfactory column efficiency and adequate performance of the chromatographic system.

a)
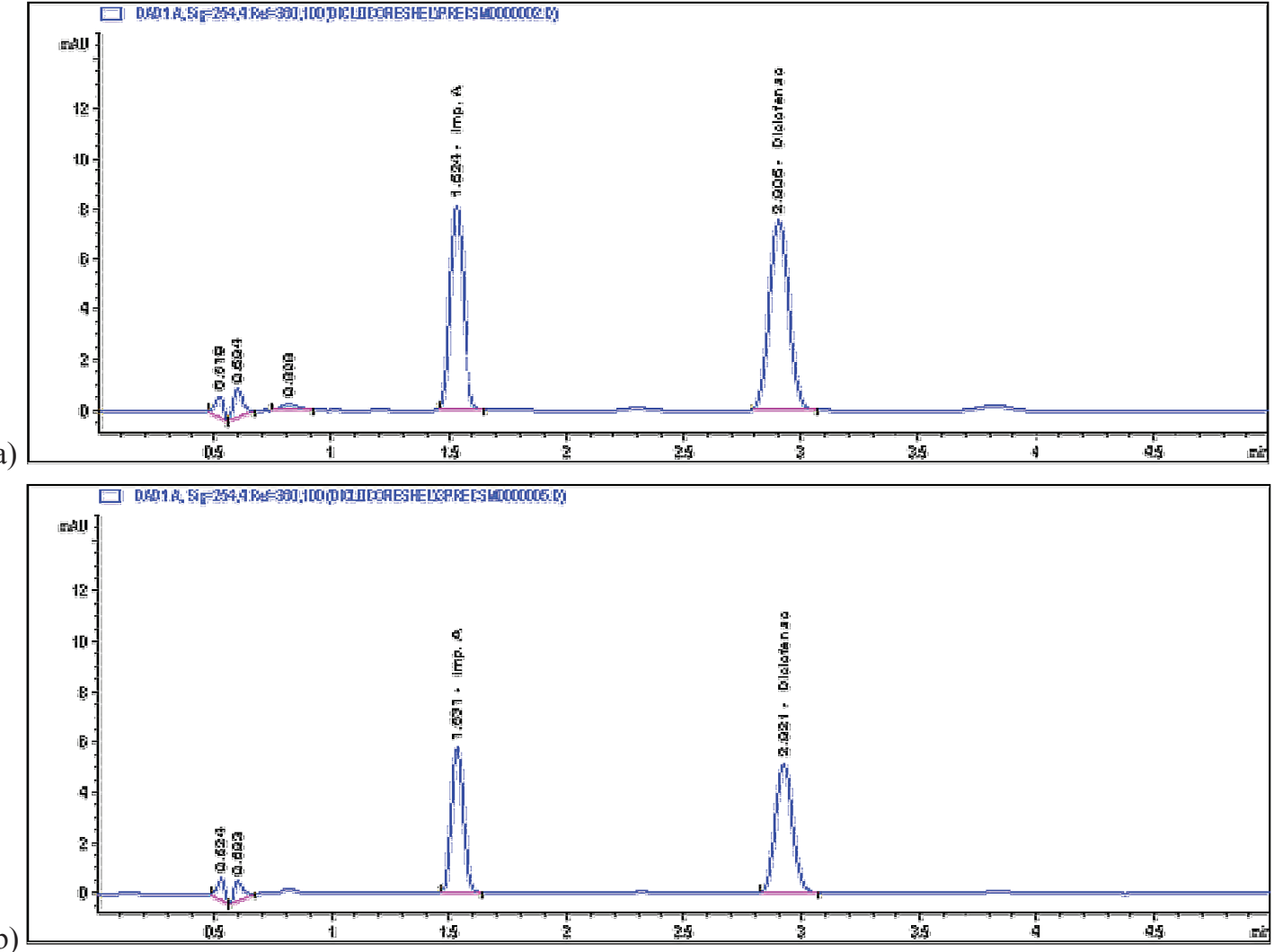

Fig 1. Chromatogram of System suitability solution for diclofenac sodium, a) injection volume $5 \mu \mathrm{L}$, b) injection volume $3 \mu \mathrm{L}$, obtained using core-shell column (C8). 
Table 1. System suitability values for the method for related substances of diclofenac sodium obtained using core-shell column (C8)

\begin{tabular}{|c|c|c|c|c|}
\hline \multirow{2}{*}{$\begin{array}{l}\text { System suit- } \\
\text { ability param- } \\
\text { eter }\end{array}$} & Imp.A & $\begin{array}{c}\text { Diclofe- } \\
\text { nac }\end{array}$ & Imp.A & $\begin{array}{c}\text { Diclofe- } \\
\text { nac }\end{array}$ \\
\hline & \multicolumn{2}{|c|}{$\mathrm{V}$ inj. $=5 \mu \mathrm{L}$} & \multicolumn{2}{|c|}{$\mathrm{V}$ inj. $=3 \mu \mathrm{L}$} \\
\hline $\operatorname{Rt}(\min )^{*}$ & 1.524 & 2.905 & 1.531 & 2.921 \\
\hline $\mathrm{k}^{\prime}$ & 2.056 & 4.826 & 2.071 & 4.859 \\
\hline As & 0.90 & 0.93 & 0.90 & 0.92 \\
\hline $\mathrm{N}$ & 3074 & 5872 & 4225 & 7563 \\
\hline $\begin{array}{l}\text { Rs } \quad \text { (Ph.Eur. } \\
\mathrm{Rs} \geq 6.5)\end{array}$ & \multicolumn{2}{|c|}{10.5} & \multicolumn{2}{|c|}{12.2} \\
\hline \multicolumn{5}{|l|}{ RSD (\%) } \\
\hline $\mathrm{Rt}^{*}$ & $0.03 \%$ & $0.05 \%$ & $0.06 \%$ & $0.06 \%$ \\
\hline Peak area* & $0.27 \%$ & $0.27 \%$ & $0.29 \%$ & $0.32 \%$ \\
\hline
\end{tabular}

The limit of detection (DL) and limit of quantification (QL) were determined on the basis of standard deviation (SD) of the response and the slope, obtained from regression analysis of relationship between the response (peak area) and the concentration of diclofenac sodium in concentration range from $0.2 \mu \mathrm{g} / \mathrm{mL}$ to $5 \mu \mathrm{g} / \mathrm{mL}(0.2,0.5,1$, $2,3$, and $5 \mu \mathrm{g} / \mathrm{mL})$. The obtained values for limit of detection, $\mathrm{DL}=0.05 \mu \mathrm{g} / \mathrm{mL}$ (volume of injection $5 \mu \mathrm{L}$ ) and $\mathrm{DL}=$ $0.03 \mu \mathrm{g} / \mathrm{mL}$ (volume of injection $3 \mu \mathrm{L}$ ) and for the limit of quantification, $\mathrm{QL}=0.17 \mu \mathrm{g} / \mathrm{mL}$ (volume of injection $5 \mu \mathrm{L}$ ) and $\mathrm{QL}=0.08 \mu \mathrm{g} / \mathrm{mL}$ (volume of injection $3 \mu \mathrm{L}$ ) are below the disregard limit $(0.5 \mu \mathrm{g} / \mathrm{mL})$ given in the Ph.Eur. monograph, indicating on satisfactory sensitivity of the method.

The obtained results have shown that using the coreshell column for determination of related substances in diclofenac sodium, satisfactory method performance are obtained in total analysis time from 5 to 7 minutes. The updated method for determination of related substances in diclofenac sodium in Ph. Eur. monograph 07/2014:1002, could be also transferred from conventional end-capped octadecylsilyl silica gel for chromatography R $(0.25 \mathrm{~m}$ $\mathrm{x} 4,6 \mathrm{~mm} ; 5 \mu \mathrm{m})$ on a suitable core-shell column (C18), in order to shorten the analysis time (25 min according to monograph 07/2014:1002, Ph.Eur.).

\section{Method for related substances in metamizole sodium}

The method for determination of related substances in metamizole sodium described in the $\mathrm{Ph}$. Eur. monograph 01/2008:1002, was transferred from conventional base deactivated octadecylsilyl silica gel for chromatography $\mathrm{R}$ (0.25 m x $4.6 \mathrm{~mm} ; 5 \mu \mathrm{m})$ on core-shell column (XB-C18, $50 \mathrm{~mm} \times 2.1 \mathrm{~mm}, 5 \mu \mathrm{m})$. The modification of the method parameters regarding the column dimensions were outside of the limits of Ph.Eur. (2.2.46). Reduction of the col- umn dimensions has the direct benefit on sensitivity and reduces the analysis time (Pereira, 2012). Due to the reduction of column size the injection volume was decreased from $10 \mu \mathrm{L}$ to $0.5 \mu \mathrm{L}$ (Figure 2). The adjustment of the method inclu-ded also reduction of the flow rate from $1 \mathrm{~mL} / \mathrm{min}$ to $0.2 \mathrm{~mL} / \mathrm{min}$, which is within the limits of Ph.Eur. (2.2.46), of nece-ssary adjustment of the flow rate, when column dimensions are changed (minimum flow rate is $0.1 \mathrm{~mL} / \mathrm{min}$ ).

Reduction of the injection volume to $1 \mu \mathrm{L}$ did not gave satisfactory separation ( $\mathrm{Rs}=2.29)$ of metamizole from impurity A (Ph.Eur., monograph limit is $\mathrm{Rs} \geq 2.5$ ). Satisfactory system suitability requirements were obtained with the injection volume of $0.5 \mu \mathrm{L}$ in total analysis time of 9 minutes (4.5 times of the retention time of metamizole, $\mathrm{Rt}=$ 2.15 ) and the value for resolution (Rs) between metamizole and impurity $\mathrm{A}(\mathrm{Rs}=3.11)$ fulfills the requirement of the $\mathrm{Ph}$.Eur monograph ( $\mathrm{Rs} \geq 2.5$ ). The obtained values from system suitability tests (Table 2) for number of theoretical plates $(\mathrm{N})$, retention factor $\left(\mathrm{k}^{\prime}\right)$, resolution $(\mathrm{Rs})$, symmetry factor (As) and relative standard deviation (RSD \%), indicate on a satisfactory column efficiency and adequate performance of the chromatographic system.

Table 2. System suitability values for the method for related substances of metamizole sodium obtained using core-shell column (C18)

\begin{tabular}{lcc}
\hline \hline $\begin{array}{l}\text { System suitability } \\
\text { parameter }\end{array}$ & Imp.A & Metamizole \\
Rt* & 1.401 & 2.148 \\
\hline k' & 1698 & 3.135 \\
$\mathrm{~N}$ & 531 & 1315 \\
$\mathrm{Rs}(\mathrm{Ph}$. Eur. Rs $\geq 2.5)$ & \multicolumn{2}{c}{3.11} \\
$\mathrm{RSD}$ & \multicolumn{2}{|}{} \\
$\quad$ Rt* & $0.16 \%$ & $0.26 \%$ \\
$\quad$ Peak area* & $0.53 \%$ & $0.55 \%$ \\
${ }^{*} n=6$. & &
\end{tabular}

The limit of detection (DL) and limit of quantification (QL) were determined on the basis of standard deviation (SD) of the response and the slope, obtained from the regression analysis of relationship between the response (peak area) and the concentration of metamizole sodium in concentration range from $5 \mu \mathrm{g} / \mathrm{mL}$ to $50 \mu \mathrm{g} / \mathrm{mL}(5,10,20$, 25,30 , and $50 \mu \mathrm{g} / \mathrm{mL}$ ). The obtained values for limit of detection, $\mathrm{DL}=0.33 \mu \mathrm{g} / \mathrm{mL}$ and for the limit of quantification, $\mathrm{QL}=0.99 \mu \mathrm{g} / \mathrm{mL}$ are below the disregard limit $(1.25$ $\mu \mathrm{g} / \mathrm{mL}$ ) given in the Ph.Eur. monograph, indicating on satisfactory sensitivity of the method.

The updated monograph 04/2014:1346 of Metamizole sodium monohydrate, for the method for determination of related substances requires an end-capped octadecylsilyl silica gel for chromatography R (50 mm x $4.6 \mathrm{~mm} ; 1.8$ $\mu \mathrm{m})$. For this type of column, the use of ultra high performance liquid chromatography system is necessary. Ac- 
a)

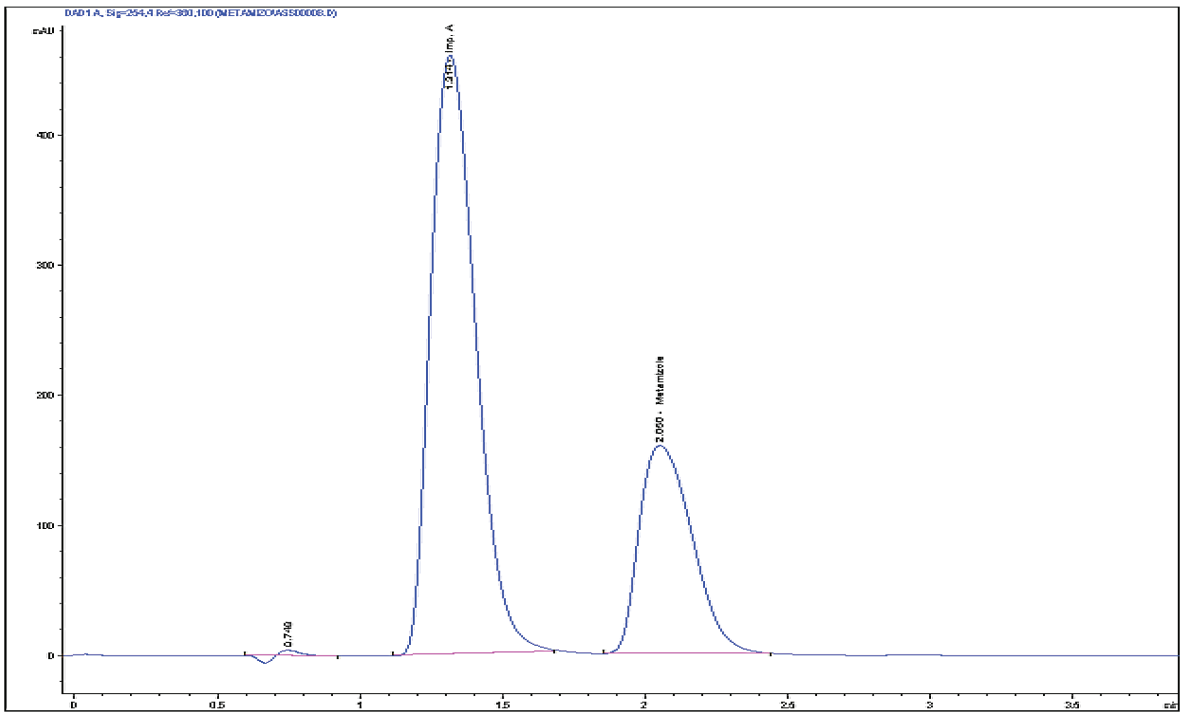

b)

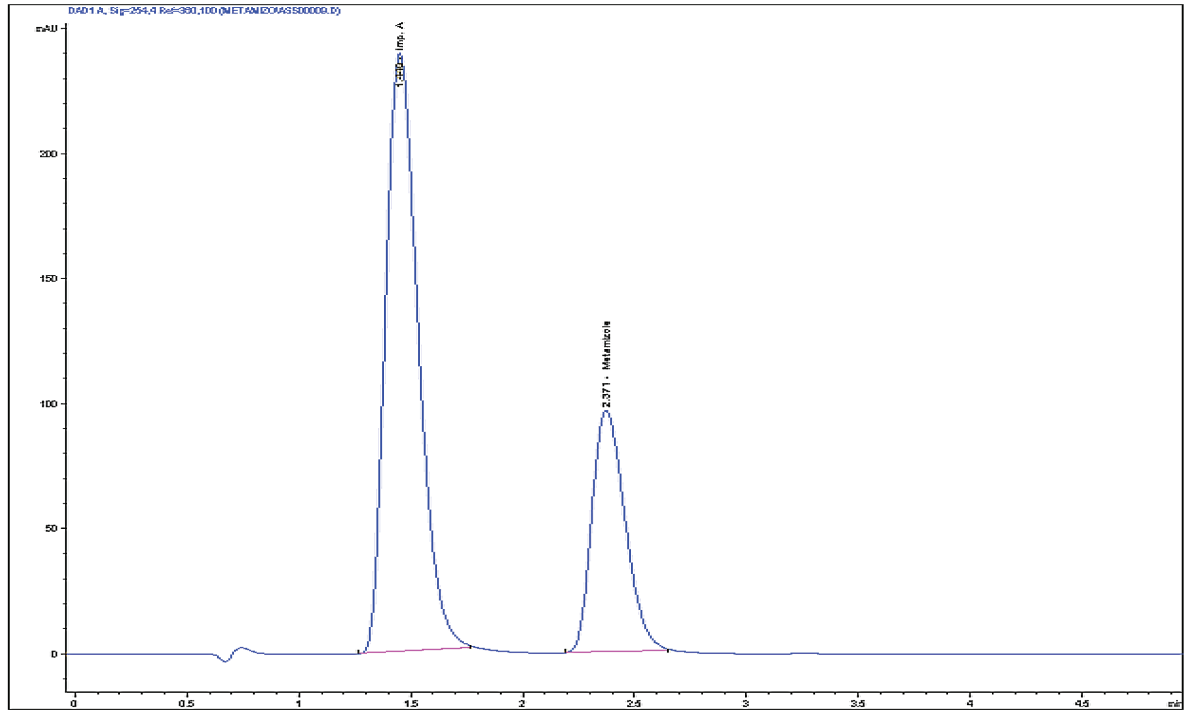

Fig 2. Chromatogram of System suitability solution for metamizole sodium: a) injection volume $1 \mu \mathrm{L}, \mathrm{b})$ injection volume $0.5 \mu \mathrm{L}$, obtained using core-shell column (C18).

cording to the monograph, the analysis times of the method should be around 9 minutes ( 4.5 times of the retention time of metamizole with $\mathrm{Rt}$ around $2 \mathrm{~min}$ ), which is the same as the analysis time obtained using core-shell column. The advantage of using the column based on core-shell technology is in obtaining comparable and satisfactory column performance on conventional HPLC equipment, available in almost any laboratory.

\section{Conclusion}

The results have shown that the pharmacopoeial methods for determination of related substances in diclofenac sodium and in metamizole sodium are successfully transferred on core-shell column, with suitable adjustment of injection volume and flow rate. The adjusted methods using core-shell columns fulfill the Ph. Eur. requirements for system suitability and achieved significant improvements in efficiency performance, resolution and sensitivity.

The advantage of using core-shell column is fast and highly efficient separation on conventional HPLC system with increased sensitivity and throughput of the method, providing enhanced lab productivity and reduced costs.

\section{References}

Berger, T.A., 2011. Characterization of a $2.6 \mu \mathrm{m}$ Kinetex porous shell hydrophilic interaction liquid chromatography column in supercritical fluid chromatography with a comparison to $3 \mu \mathrm{m}$ totally porous silica. J Chromatogr A. 1218(28):45594568 . 
Brice, R.W., Zhang, X., Colón, L.A. 2009. Fused-core, sub2 microm packings, and monolithic HPLC columns: a comparative evaluation. J Sep Sci. 32(15-16):2723-2731.

Destefano, J.J., Langlois, T.J., Kirkland, J.J. 2008. Characteristics of superficially-porous silica particles for fast HPLC: some performance comparisons with sub-2-microm particles. J Chromatogr Sci. 46(3):254-260.

Destefano, J.J., Schuster, S.A., Lawhorn, J.M., Kirkland, J.J. 2012. Performance characteristics of new superficially porous particles. J Chromatogr A. Oct 5;1258:76-83.

Guiochon, G., Gritti, F., 2011. Shell particles, trials, tribulations and triumphs. J Chromatogr A. 1218(15):1915-1938.

European pharmacopoeia, 8th edition, 2013.

Fekete, S., Berky, R., Fekete, J., Veuthey, J.L., Guillarme, D. 2012. Evaluation of a new wide pore core-shell material (Aeris WIDEPORE) and comparison with other existing stationary phases for the analysis of intact proteins. J Chromatogr A. 1236:177-188.

Hayes, R., Ahmed, A., Edge, T., Zhang, H. 2014. Core-shell particles: preparation, fundamentals and applications in high performance liquid chromatography J Chromatogr A. 1357, 36-52.

Kirkland, J. J., Schuster, S.A., Johnson, W.L., Boyes, Barry. E. 2013. Fused -core particle technology in high-performance liquid chromatography: An overview. J. Pharm. Anal. 3 (5) $303-312$.

Naijun, Wu., Andrew, M. 2007. Clausen Fundamental and practical aspects of ultrahigh pressure liquid chromatography for fast separations. J. Sep. Sci. 30 (8) 1167-1182.

Pereira, L., 2012. An Overview of Core Enhanced Technology for Fast, High Efficiency HPLC, Chromatography today, May, $14-22$.

Ruta, J., Zurlino, D., Grivel, C., Heinisch, S., Veuthey, J.L., Guillarme, D. 2012. Evaluation of columns packed with shell particles with compounds of pharmaceutical interest. J Chromatogr A. Mar 9; 1228:221-231.

Song, W., Pabbisetty, D., Groeber, E.A., Steenwyk, R.C., Fast, D.M. 2009. Comparison of fused-core and conventional particle size columns by LC-MS/MS and UV: application to pharmacokinetic study. J Pharm Biomed Anal. 15;50(3):491500 .

Schuster, S.A., Boyes, B.E., Wagner, B.M., Kirkland, J.J., 2012. Fast high performance liquid chromatography separations for proteomic applications using Fused-Core ${ }^{\circledR}$ silica particles. J Chromatogr A. 1228:232-241.

Wu, X., You, L., Di, B., Hao, W., Su, M., Gu, Y., Shen, L. 2013. Novel chiral core-shell silica microspheres with trans(1R,2R)-diaminocyclohexane bridged in the mesoporous shell: synthesis, characterization and application in high performance liquid chromatography. J Chromatogr A. 1299:78-84.

Yang, P., McCabe, T., Pursch, M. 2011. Practical comparison of LC columns packed with different superficially porous particles for the separation of small molecules and medium size natural products. J Sep Sci. 34(21):2975-2982.

\title{
Трансфер на фармакопејски методи за определување на онечистувања базирани на реверзно-фазна течна хроматографија од конвенционална на core-shell колона
}

\author{
Катерина Брезовска*1, Габриела Петровска ${ }^{1}$, Јелена Ацевска ${ }^{1}$, Наталија Наков ${ }^{1}$, \\ Ана Поцева-Пановска ${ }^{1}$, ЈасминаТониќ-Рибарска $^{1}$, Маја Хаџиева ${ }^{2}$, Анета \\ Димитровска ${ }^{1}$
}

\author{
'Фармацевйски факулиеей, Универзииетй „Св. Кирил и Мейояиј”, Скойје, Рейублика Макеоонија \\ ${ }^{2}$ Алкалоия АД Скойје, 1000 Скойје, Рейублика Макеоонија
}

Клучни зборови: core-shell колона, HPLC, диклофенак натриум, метамизол натриум

Core-shell силика честичките, се развиени како нов материјал за хроматографски стационарни фази, со цел обезбедување на високо ефективно разделување на мали и големи молекули, како и на комплексни смеси со притисоци компатибилни со конвенционална HPLC опрема. Целта на овој труд беше да се покаже применливоста на HPLC колоните базирани на core-shell технологија за определување на сродни супстанции на диклофенак натриум и на метамизол натриум со примена на методите опишани во соодветните монографии во Европската фармакопеја. Резултатите покажаа дека предложените методи може успешно да се трансферираат на core-shell колона со соодветно подесување на волуменот на инјектирање и протокот на мобилната фаза. Предноста на употребата на core-shell колона е брзо и ефикасно разделување на конвенционален HPLC систем, со зголемена осетливост на методот и висока ефикасност на анализата, овозможувајќи зголемена продуктивност на лабораторијата и намалување на трошоците. 


\title{
Essential oil composition of Salvia fruticosa Mill. populations from Balkan Peninsula
}

\author{
Ivana Cvetkovikj”, Gjoshe Stefkov, Marija Karapandzova and Svetlana Kulevanova \\ ${ }^{1}$ Institute of Pharmacognosy, Faculty of Pharmacy, Ss. Cyril and Methodius University, \\ Majka Tereza 47, 1000 Skopje, R. Macedonia
}

Received: January 2015; Accepted: April 2015

\begin{abstract}
The aim of this study was to investigate the yield and chemical composition of the essential oil (EO) isolated from 19 different populations of Salvia fruticosa Mill. (Greek sage, Lamiaceae) from nine different regions of Albania and Greece. The EO yield ranged from $0.25 \%$ to $4.00 \%$. Eighteen of the total analyzed populations met the Ph.Eur.8.0 minimal requirements concerning the essential oil yield. Performing GC/FID/MS analyses, a total of 75 components were detected, representing 79.15-97.83\% of the oils. Thirteen components ( $\alpha$-pinene, camphene, $\beta$-pinene, myrcene, 1,8-cineole, $\gamma$-terpinene, cis-thujone, trans-thujone, camphor, terpinene-4-ol, trans-(E)-caryophyllene, aromadendrene and $\alpha$-humulene) were identified in all samples, with 1,8-cineole as a predominant constituent. Statistical analysis showed that the geographical origin of plants did not have significant influence on the variation in chemical composition of the Greek sage essential oil.
\end{abstract}

Key words: Greek sage, yield, GC/FID/MS, essential oil composition, Greece, Albania

\section{Introduction}

The genus Salvia L. from Lamiaceae is one of the largest genera in this family and includes around 1000 species that have almost cosmopolitan distribution (Kintzios, 2000). It is an important aromatic genus which is frequently used as herbal tea and as a source of essential oils and aroma chemicals (Karamanos, 2008). With significant economic importance are the pharmacopoeial herbs: $S$. fruticosa Mill. (Syn. S. triloba L. or Greek sage) and S. officinalis L. (Dalmatian, common or garden sage) (Kosar et al., 2005).

S. fruticosa is an endemic species of the Eastern Mediterranean basin (Ali-Shtayeh et al., 2000; Carmona et al., 2005; Elmann et al., 2009). Naturalized can be found in parts of the Western Mediterranean regions like Mal-

\footnotetext{
*ivanacvetkovikj@ff.ukim.edu.mk, ivanacvetkovikj@gmail.com
}

ta, Spain and Portugal. S. fruticosa is the most widespread sage species in Greece, forming extended populations in littoral areas of the mainland, as well as the Ionian and Aegean islands (Kintzios, 2000).

The leaves of this herb have been used for treatment of various skin, blood, and infectious ailments as well as ailments of the digestive, circulatory and respiratory systems (Ali-Shtayeh et al., 2000; Carmona et al., 2005). Greek sage posses hypoglycemic effect and can be used against inflammations, hepatitis, and tuberculosis (Pitarokili et al., 2003). On the other hand the essential oil (EO) showed good antimicrobial activity against food borne bacteria (Longaray Delamare et al., 2007) and has antifungal activity (Pitarokili et al., 2003). Numerous investigations have been reported dealing with the essential oil composition and their biological activity, often referring to the $S$. offcinalis species (Pierozan et al., 2009; Giweli et al., 2013).

However, to the best of our knowledge, there is limited information on the chemical composition of the essen- 
tial oil isolated from $S$. fruticosa from Balkan Peninsula. Therefore the aim of the present work was to assess and compare the oil yield and composition from Greece and Albania as native area of distribution of this herb.

\section{Experimental}

\section{Plant collection}

Plant samples were collected from 19 different (18 indigenous and one non-indigenous) populations of Salvia fruticosa Mill., Lamiaceae, from nine different locations from Greece and Albania. The leaves were air dried, packed in paper bags and kept in a dark and cold place until analysis. Plant identity was verified and voucher specimens were deposited at the Institute of Pharmacognosy, Faculty of Pharmacy, Skopje, R. Macedonia (Table 1).

\section{Essential oil isolation}

The EOs were isolated from dried, cut leaves, by hydrodistillation in all-glass Clevenger apparatus for 2 hours according to pharmacopoeial method (Ph. Eur. 8.0., 2014). The oil yield was measured and presented in Table 1 .

\section{Analysis of essential oils' chemical composition}

EO samples in hexane $(1: 1000)$ were analyzed on Agilent 7890A Gas Chromatography system equipped with FID detector and Agilent 5975C mass spectrometer. For that purpose, HP-5ms capillary column $(30 \mathrm{~m}$ x $0.25 \mathrm{~mm}$, film thickness $0.25 \mu \mathrm{m}$ ) was used. Analytical conditions were as follows: oven temperature at $60{ }^{\circ} \mathrm{C}(0 \mathrm{~min}), 3{ }^{\circ} \mathrm{C} /$ $\min$ to $240^{\circ} \mathrm{C}(1 \mathrm{~min})$ and at the end increased to $280^{\circ} \mathrm{C}$ at a rate of $10^{\circ} \mathrm{C} / \mathrm{min}(1 \mathrm{~min})$; helium as carrier gas at a flow rate of $1 \mathrm{ml} / \mathrm{min}$; injector temperature $220^{\circ} \mathrm{C}$ and that of the FID detector $270^{\circ} \mathrm{C}$. One $\mu$ l of each sample was injected at a split ratio of $1: 1$. The mass spectrometry conditions were: ionization voltage $70 \mathrm{eV}$, ion source temperature 230 ${ }^{\circ} \mathrm{C}$, transfer line temperature $280{ }^{\circ} \mathrm{C}$ and mass range from 50 - $550 \mathrm{Da}$. The MS was operated in scan mode.

\section{Identification of the components}

The compounds were identified on the basis of literature (Adams, 2007) and estimated Kovat's (retention) indices that were determined using a mixture of homologous series of normal alkanes (C9-C25) analyzed under Automated Mass Spectral Deconvolution and Identification System (AMDIS)' conditions. Confirmation was made by

Table 1. Sampling localities and essential oil (EO) yields of 19 Salvia fruticosa Mill. populations from Balkan Peninsula

\begin{tabular}{|c|c|c|c|c|c|c|}
\hline \multirow{2}{*}{ Population } & \multirow{2}{*}{ Country (Code) } & \multirow{2}{*}{ Locality } & Latitude & Longitude & \multirow{2}{*}{$\begin{array}{l}\text { Vouchers } \\
\text { specimens }\end{array}$} & \multirow{2}{*}{$\begin{array}{c}\text { EO Yield } \\
{[\%]^{1)}}\end{array}$} \\
\hline & & & $(\mathrm{N})$ & (E) & & \\
\hline ALB 1 & Albania (ALB) & Porto Palermo-Qeparo 1 & $42^{\circ} 03^{\prime} 09^{\prime \prime}$ & $19^{\circ} 49^{\prime} 45^{\prime \prime}$ & ALBStPQ1/11 & 2.80 \\
\hline ALB 2 & Albania (ALB) & Porto Palermo-Qeparo 2 & $42^{\circ} 03^{\prime} 09^{\prime \prime}$ & $19^{\circ} 49^{\prime} 45^{\prime \prime}$ & ALBStPQ2/11 & 2.60 \\
\hline ALB 3 & Albania (ALB) & Porto Palermo-Qeparo 3 & $42^{\circ} 03^{\prime} 09^{\prime \prime}$ & $19^{\circ} 49^{\prime} 45^{\prime \prime}$ & ALBStPQ3/11 & 2.75 \\
\hline ALB 4 & Albania (ALB) & Porto Palermo-Qeparo 4 & $42^{\circ} 03^{\prime} 09^{\prime \prime}$ & $19^{\circ} 49^{\prime} 45^{\prime \prime}$ & ALBStPQ4/11 & 3.40 \\
\hline ALB 5 & Albania (ALB) & Llogora & $40^{\circ} 11^{\prime} 55^{\prime \prime}$ & $19^{\circ} 34^{\prime} 21^{\prime \prime}$ & ALBStL1/11 & 0.25 \\
\hline ALB 6 & Albania (ALB) & Palase & $40^{\circ} 09^{\prime} 54^{\prime \prime}$ & $19^{\circ} 37^{\prime} 29^{\prime \prime}$ & ALBStP2/11 & 2.45 \\
\hline ALB 7 & Albania (ALB) & Dhermi & $40^{\circ} 09^{\prime} 00^{\prime \prime}$ & $19^{\circ} 38^{\prime} 00^{\prime \prime}$ & ALBStD3/11 & 2.10 \\
\hline ALB 8 & Albania (ALB) & Borsh & $40^{\circ} 03^{\prime} 45^{\prime \prime}$ & $19^{\circ} 51^{\prime} 24^{\prime \prime}$ & ALBStB4/11 & 1.70 \\
\hline ALB 9 & Albania (ALB) & Ilias-Vuno & $40^{\circ} 08^{\prime} 23^{\prime \prime}$ & $19^{\circ} 41^{\prime} 37^{\prime \prime}$ & ALBStIv5/11 & 2.05 \\
\hline ALB 10 & Albania (ALB) & l & / & / & ALBStK11/13 & 1.80 \\
\hline ALB 11 & Albania (ALB) & Dhermi & $40^{\circ} 09^{\prime} 00^{\prime \prime}$ & $19^{\circ} 38^{\prime} 00^{\prime \prime}$ & ALBStD1ju/13 & 2.50 \\
\hline ALB 12 & Albania (ALB) & Dhermi & $40^{\circ} 09^{\prime} 00^{\prime \prime}$ & $19^{\circ} 38^{\prime} 00^{\prime \prime}$ & ALBStD1m/14 & 1.60 \\
\hline ALB 13 & Albania (ALB) & Dhermi & $40^{\circ} 09^{\prime} 00^{\prime \prime}$ & $19^{\circ} 38^{\prime} 00^{\prime \prime}$ & ALBStD2ju/14 & 4.00 \\
\hline GR 14 & Greece (GR) & Kavoussi 1 & $35^{\circ} 07^{\prime} 00^{\prime \prime}$ & $25^{\circ} 51^{\prime} 00^{\prime \prime}$ & GRStK1/11 & 1.60 \\
\hline GR 15 & Greece (GR) & Kavoussi 3 & $35^{\circ} 07^{\prime} 00^{\prime \prime}$ & $25^{\circ} 51^{\prime} 00^{\prime \prime}$ & GRStK3/11 & 1.60 \\
\hline GR 16 & Greece (GR) & Rhizoscaro 1 & / & I & GRStR1/11 & 3.60 \\
\hline GR 17 & Greece (GR) & Rhizoscaro 2 & / & l & GRStR2/11 & 3.85 \\
\hline GR 18 & Greece (GR) & Vrysses 2 & $35^{\circ} 21^{\prime} 45^{\prime \prime}$ & $24^{\circ} 15^{\prime} 11^{\prime \prime}$ & GRStV2/11 & 1.20 \\
\hline GR 19 & Greece (GR) & Vrysses 3 & $35^{\circ} 21^{\prime} 45^{\prime \prime}$ & $24^{\circ} 15^{\prime} 11^{\prime \prime}$ & GRStV3/11 & 2.40 \\
\hline
\end{tabular}


comparing the mass spectra of the components present in the EOs with the reference spectra obtained from Nist, Wiley and Adams mass spectra libraries. Quantification of the EOs components was performed using the normalization method of the GC/FID peak areas without any correction factors.

\section{Statistical analysis}

The significance of differences between oil samples was tested by analysis of variance (ANOVA) using the package Excel for Windows 7 and represented by critical value of an F-test $(F)$ and statistical significance $(p)$. ANOVA was performed on the geographical origin of plants as grouping factor.

\section{Results and discussion}

\section{Essential oil yield}

The EO yield of 18 indigenous and one non-indigenous (commercial) population of Greek sage from nine different locations from Greece and Albania ranged from $2.50 \mathrm{ml} / \mathrm{kg}$ to $40.00 \mathrm{ml} / \mathrm{kg}(0.25-4.00 \%)$ (Table 1$)$. The highest yield was recorded in two $S$. fruticosa populations, one from Dhermi, Albania (ALB 13) and the other population from Vrysses, Greece (GR 17), while the lowest was found in the Albanian population (ALB 5) from Llogora. Eighteen of the analyzed 19 populations met the Ph.Eur.8.0 minimal requirements concerning the essential oil yield.

\section{EO composition}

Data analysis of the EO chemical composition revealed six different classes of components: monoterpene hydrocarbons $(\mathrm{MH})$, oxygen-containing monoterpenes (OMT), sesquiterpene hydrocarbons ( $\mathrm{SH}$ ), oxygen-containing sesquiterpenes (OST), diterpenes (D) and non-terpene components (NT). Generally, OMT was dominant fractions, present with more than $45 \%$ in all tested samples, followed by smaller amounts of MT or ST (Table 2). On the other hand, the diterpene chemical class was absent from two Greek populations (GR 14 and GR 17).

GC/FID/MS analyses of the isolated EOs revealed a total of 75 compounds representing $79.15-97.83 \%$ of the oils (Table 2). Thirteen components were detected in all analyzed EOs (Figure 1) with 1,8-cineole as predominant constituent. Eight components: $\alpha$-pinene (0.36-6.03\%), camphene (tr.-6.04\%), $\beta$-pinene (tr.-6.14\%), 1,8-cineole (23.71-58.95\%), cis-thujone (1.17-10.37\%), trans-thujone (0.95-4.07\%), camphor (tr.-19.19\%) and trans- $(E)$-caryophyllene $(0.57-15.96 \%)$ that were found in amounts higher than $3.00 \%$ were considered as principal components of Greek sage essential oils.

Our results are in full agreement with Giweli et al. (2013) who reported high amounts of 1,8-cineole, followed by camphor, $\beta$-pinene, myrcene and $\alpha$-pinene in their samples of $S$. triloba provided from Libya. Additionally, Kosar et al. (2005), confirmed 1,8-cineole and camphor as predominant constituents in their Turkish sage samples and the same applies for $S$. fruticosa from Greece (Pitarokili et al., 2003; Pavlidou et al., 2004). On the other hand, Longa-

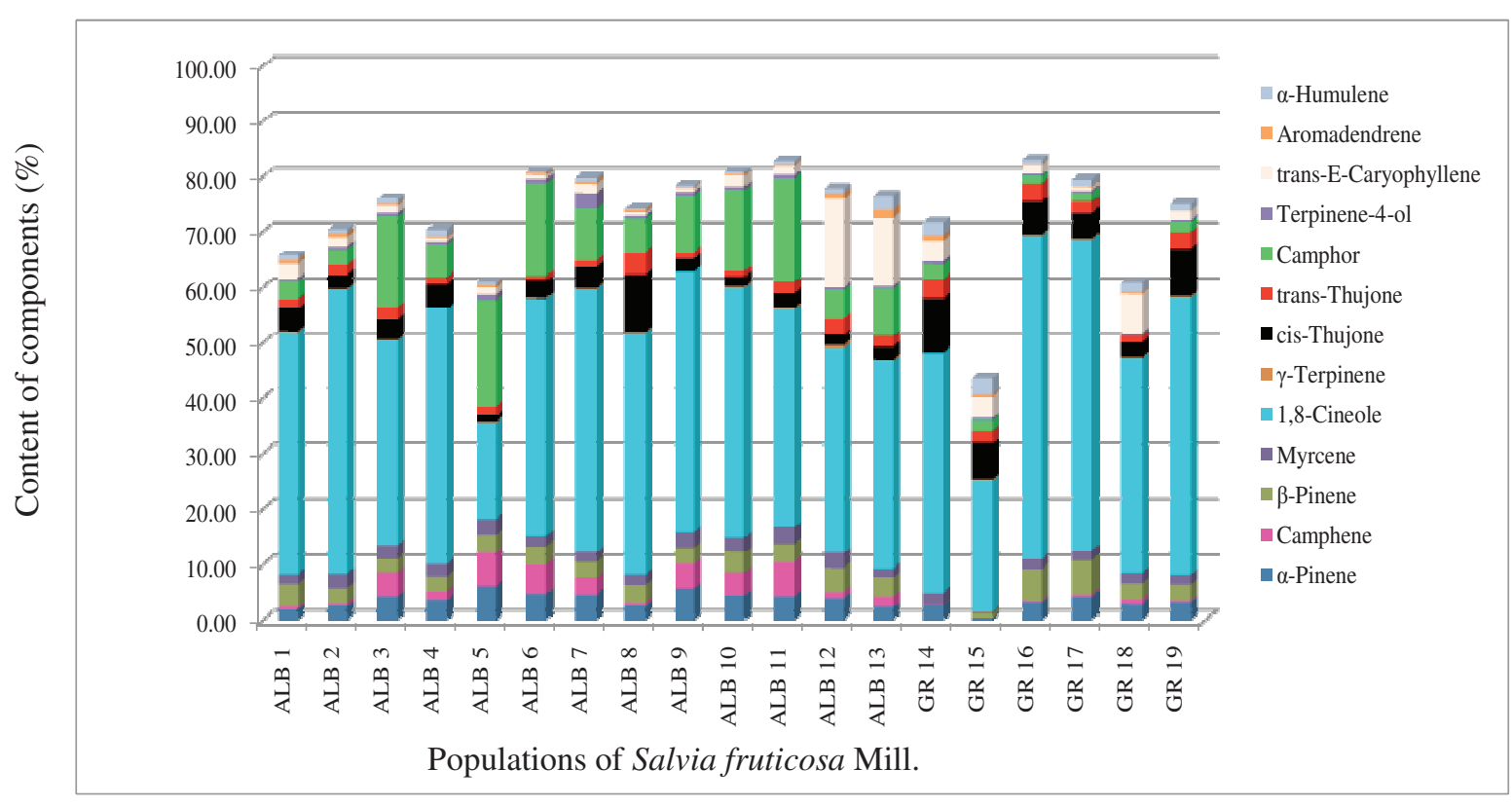

Fig. 1. Thirteen predominant EO constituents identified in all 19 populations of S. fruticosa Mill. 


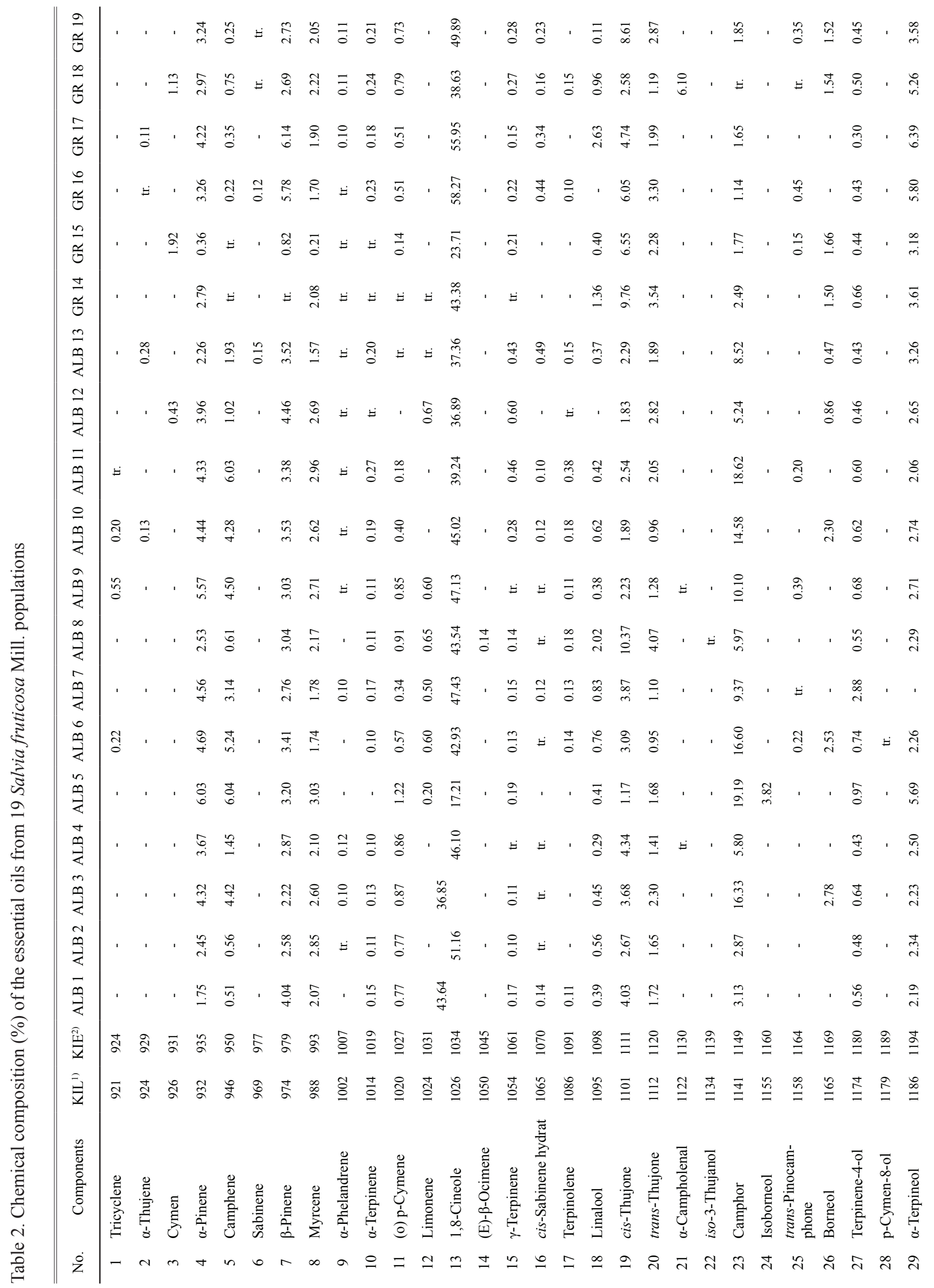

Maced. pharm. bull., 61 (1) 19 - 26 (2015) 


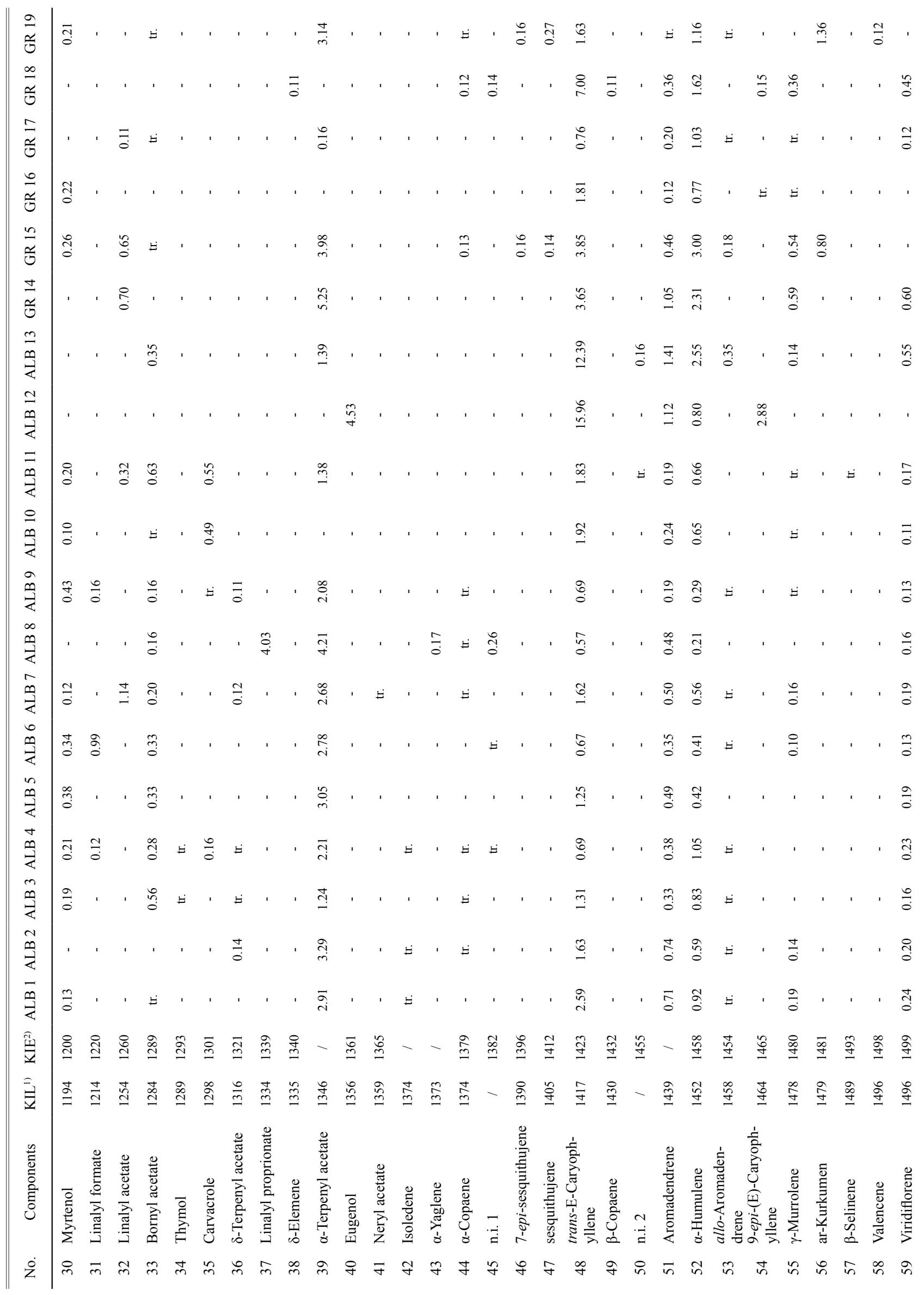

Макед. фарм. билт., 61 (1) 19 - 26 (2015) 


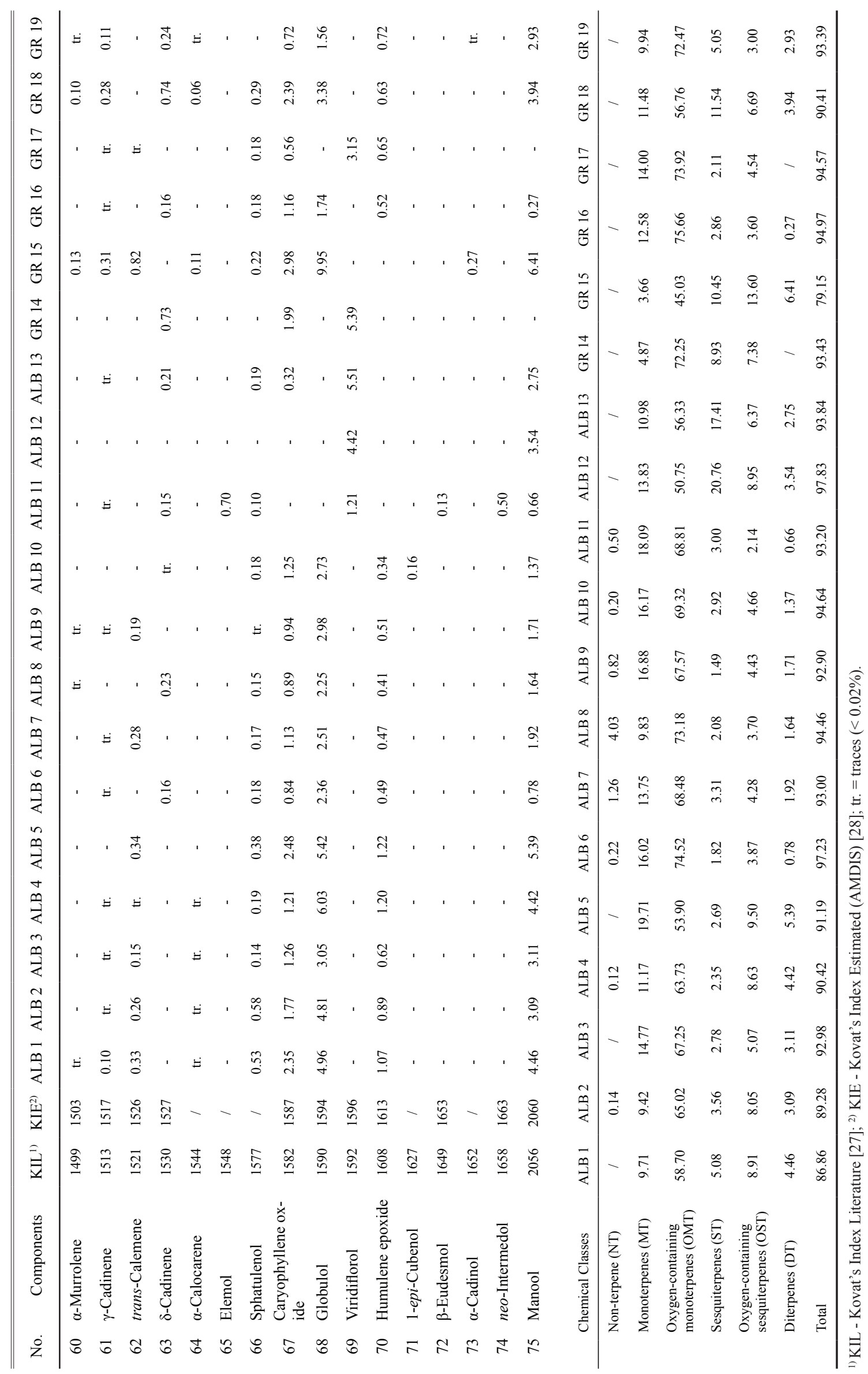

Maced. pharm. bull., 61 (1) 19 - 26 (2015) 
ray Delamare et al. (2007) and Pierozan et al. (2009) found $\alpha$-thujone as a major compound in their analyzed populations which is in contrast with our results and other available data.

Taking into concideration high cineole and camphor content, compounds with well established antibacterial properties, potential antimicrobial activity of the essential oil of $S$. fruticosa from Greece and Albania can be foreseen. Positive results of this activity could be used in the pharmaceutical industry, food production, and in the production of cosmetics or in any other purposes as substituted for S. officinalis.

Statistical analysis of variance (ANOVA) of the chemical composition of the essential oils for the complete data set of 19 samples revealed that there wasn't a statistically significant difference in the EO composition of $S$. fruticosa populations, regardless its origin.

\section{Conclusion}

The essential oils of 19 different populations of $S$. fruticosa was chemically analyzed and the oil yields were determinate and compared with the pharmacopeial requirements. The EO yield ranged from $0.25 \%$ to $4.00 \%$ and eighteen of the total analyzed populations met the minimal requirements $(\geq 1.20 \%)$. Regarding the chemical analysis, a total of 75 components were detected, and 13 components ( $\alpha$-pinene, camphene, $\beta$-pinene, myrcene, 1,8 -cineole, $\gamma$-terpinene, $c i s$-thujone, trans-thujone, camphor, terpinene-4-ol, trans-(E)-caryophyllene, aromadendrene and $\alpha$-humulene) were present in all samples. 1,8-Cineole was a predominant constituent in all sage populations, followed by camphor.

The results obtained from the essential oils isolated from Greek sage correlate with the available literature data, and the statistical analysis showed that the oil composition is not influenced by the geographical locations.

\section{Acknowledgements}

SEE-ERA.NET PLUS Joint Call project: ERA 64/01.

\section{References}

Adams, R.P., 2007. Identification of Essential Oil Components by Gas Chromatography/Mass Spectrometry. $4^{\text {th }}$ Ed. Illinois: Allured Publishing Corporation, IL, USA, pp 9-31.
Ali-Shtayeh, M.S., Yaniv, Z., Mahajna, J., 2000. Ethnobotanical survey in the Palestinian area: a classification of the healing potential of medicinal plants. J. Ethnopharmacol. 73, 22132.

Automated Mass Spectral Deconvolution and Identification System software (AMDIS ver.2.1.), National Institute of Standards and Technology (NIST), Standard Reference Data Program, Gaithersburg, MD (USA).

Carmona, M.D., Llorach, R., Obon, C., Rivera, D., 2005. "Zahraa", a Unani multi component herbal tea widely consumed in Syria: components of drug mixtures and alleged medicinal properties. J. Ethnopharmacol. 102, 344-50.

Elmann, A., Mordechay, S., Rindner, M., Larkov, O., Elkabetz, M., Ravid, U., 2009. Protective Effects of the Essential Oil of Salvia fruticosa and Its Constituents on Astrocytic Susceptibility to Hydrogen Peroxide-Induced Cell Death. J. Agric. Food Chem. 57, 6636-41.

European Pharmacopoeia, $8^{\text {th }}$ Edition, Council of Europe, Strasbourg, 2014.

Giweli, A.A., Dzamic, A.M., Sokovic, M., Ristic, M.S., Janackovic, P., Marin, P.D., 2013. The Chemical composition, antimicrobial and antioxidant activities of the essential oil of Salvia fruticosa Growing wild in Libya. Arch. Biol. Sci. 65, 32129.

Karamanos, A.J., 2008. Cultivation and breeding. The cultivation of Sage. In Kintzios SE (Ed.), SAGE "The Genus Salvia” (pp.93 - 108). Amsterdam: Harwood Academic Publishers.

Kintzios, S.E., 2000. SAGE "The Genus Salvia", Amsterdam: Harwood Academic Publishers.

Kosar, M., Tunalier, Z., Ozek, T., Kurkcuoglu, M., Husnu Can Baser, K., 2005. A simple method to obtain essential oils from Salvia triloba L. and Laurus nobilis L. by using microwave-assisted hydrodistillation. Zeitschrift fur Naturforschung C 60, 501-4.

Longaray Delamare, A.P., Moschen-Pistorello, I.T., Artico, L., Atti-Serafini, L., Echeverrigaray, S., 2007. Antibacterial activity of the essential oils of Salvia officinalis L. and Salvia triloba L. cultivated in South Brazil. Food Chem. 100, 603-8.

Pavlidou, V., Karpouhtsis, I., Franzios, G., Zambetaki, A., Scouras, Z., Mavragani-Tsipidou, P., 2004. Insecticidal and genotoxic effects of essential oils of Greek sage, Salvia fruticosa, and Mint, Mentha pulegium, on Drosophila melanogaster and Bactrocera oleae (Diptera: Tephritidae). J. Agric. Urban Entomol. 21, 39-49.

Pierozan, M.K., Pauletti, G.F., Rota, L., Atti dos Santos, A.C., Lerin, L.A., Di Luccio, M., Mossi, A.J., Atti-Serafini, L., Cansian, R.L., Oliveira, J.V., 2009. Chemical characterization and antimicrobial activity of essential oil of Salvia L. species. Ciencie e Technologia de Alimentos 29, 764-70.

Pitarokili, D., Tzakou, O., Loukis, A., Harvala, C., 2003. Volatile metabolites from Salvia fruticosa as antifungal agents in soil borne pathogens. J. Agric. Food Chem. 51, 3294-301. 
Резиме

\title{
Состав на етерично масло од популации на Salvia fruticosa Mill. од Балканскиот полуостров
}

\author{
Ивана Цветковиќ*, Ѓоше Стефков, Марија Карапанџова и Светлана Кулеванова

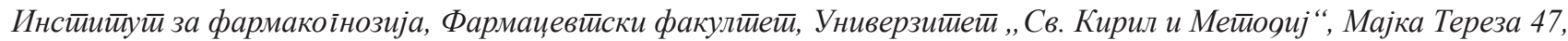 \\ 1000 Скойје, Рейублика Макеоонија
}

Клучни зборови: Грчка жалфија, принос, GC/FID/MS, состав на етерични масла, Грција, Албанија.

Целта на оваа студија беше да се испита приносот и хемискиот состав на етеричните масла изолирани од 19 различни популации на Salvia fruticosa Mill. (грчка жалфија, Lamiaceae) од девет различни региони од Р. Албанија и Р. Грција. Содржината на маслата се движи од $0,25 \%$ до 4,00\%. Осумнаесет од анализираните 19 популации одговараат на пропишаните минимални барања во европската фармакопеја за содржината на маслото. Сo GC/FID/ MS анализа на соодветните етерични масла, беа идентификувани вкупно 75 компоненти, што претставуваат 79,15$97,83 \%$ од вкупната содржина. Тринаесет компоненти ( $\alpha$-пинен, камфен, $\beta$-пинен, мирцен, 1,8 -цинеол, $\gamma$-терпинен, cis-тујон, trans-тујон, камфор, терпинен-4-ол, trans-(Е)-кариофилен, аромадендрен и $\alpha$-хумулен), се детектирани во сите примероци, а 1,8-цинеол е определена како најзастапена поединечна компонента. Статистичката анализа на резултатите покажа дека географското потекло на растенијата нема значајно влијание на варијациите во хемискиот состав на етеричното масло од S. fruticosa. 


\title{
Determination of mineral element content of Pelargonium roseum plant by ICP-MS
}

\author{
Carmen Gâlea ${ }^{1}$, Gabriel Hancu, Attila Csiszer ${ }^{3}$, Csengele Monika Jeszenszky ${ }^{4}$, \\ Enikő Barabás ${ }^{5}$ \\ ${ }^{1}$ Department of Pharmaceutical Chemistry, Faculty of Pharmacy, University "Lucian Blaga", Sibiu, Romania \\ ${ }^{2}$ Department of Pharmaceutical Chemistry, Faculty of Pharmacy, University of Medicine and Pharmacy, \\ Tîrgu Mureş, Romania \\ ${ }^{3}$ National Institut of Public Health, Tîrgu Mureş, Romania \\ ${ }^{4}$ Faculty of Medicine, University of Medicine and Pharmacy, Tîrgu Mureş, Romania \\ ${ }^{5}$ Department of Botany and Cell Biology, Faculty of Pharmacy, University of Medicine and Pharmacy, \\ Tîrgu Mureş, Romania
}

Received: 6 December 2015; Accepted: 10 January 2016

\begin{abstract}
Microelement content of different vegetative parts of Pelargonium roseum was evaluated by inductively coupled plasma - mass spectrometry (ICP-MS) technique. The analytical method allowed the determination of 20 elements ( $\mathrm{Li}, \mathrm{Be}, \mathrm{Cr}, \mathrm{Mn}, \mathrm{Fe}, \mathrm{Co}, \mathrm{Ni}, \mathrm{Cu}, \mathrm{Zn}, \mathrm{Ga}$, $\mathrm{Se}, \mathrm{Rb}, \mathrm{Sr}, \mathrm{Ag}, \mathrm{Cd}$, In, Ba, Tl, Pb, Bi). Samples from different vegetative parts (roots, lignified stems, green stalks, leafs, blooms) were analyzed and compared with soil samples. The vegetative part of the plant contained significant quantities of manganese, zinc and especially iron. The results can be very useful for the determination of the recommended doses of plant products for use in medicinal plant products considering its nutritional content and pharmacological functions.
\end{abstract}

Keywords: Pelargonium roseum, Microelemental analysis, ICP-MS, Dietary supplements

\section{Introduction}

Pelargonium roseum is a species of aromatic hairy herbaceous shrub indigenous to Southern Africa belonging to the Geraniaceae family, which was introduced and nowadays is highly cultivated in the Mediterranean part of Europe, Northern Africa and Central America. Sometimes this herb is also called Pelargonium graveolens, but despite the double name, it is the same herb-Rose geranium. It is called Rose Geranium, because this plant has both the characteristics in itself - Rose, because of the scent when it blooms and Geranium, because it is from the same genus

\footnotetext{
* e-mail: gabriel.hancu@umftgm.ro
}

as the common Geraniums (Geraniaceae) (Lis-Balchin et al., 1996).

Pelargonium roseum has a woody, straight stem with branches; its leaves are usually alternate, palmate lobed or pinnate, often on long stalks, and sometimes with light or dark pattern; covered with short, rough hairs, which give the plant a strong, pleasant rose-like scent. The erect stems bear five-petaled flowers in umbel-like clusters; the flower has a single symmetry plane (zygomorphic), which distinguishes it from the Geranium flower, which has radial symmetry (actinomorphic). It is an annual plant, but when dwarfed and domesticated it becomes perennial. Roots grow up to $60 \mathrm{~cm}$ in soil, fresh leaves grow in the whole year if the temperatures are not too low and its flowers 
blooms actively between June and October (Fig. 1) (Lancu et al., 2013).

It is cultivated mainly by the perfume industry and for aromatherapy and there are subspecies with various other scents. Calming and grounding, Pelargonium roseum essential oil helps to reduce feelings of stress and worry; it's balancing effect on the body and mind makes this oil an excellent choice to uplift the mood and promote feelings of well being (Dorman and Deans, 2000; Moyo and van Staden, 2014).

Essential oil of Pelargonium roseum is used in herbal medicine for its astringent and chemostatic effect, also it regulates the bloodstream, stimulates the adrenal glands and lymphatic system which in combination with its diuretic properties makes this essential oil excellent in the fight against cellulite and fluid retention in the body (Cavar and Maksimovic, 2012; Dzamic et al., 2014).

The antiseptic, antimicrobial and antifungal properties of Pelargonium roseum essential oil were also assessed and evaluated, with encouraging results, when compared with the effects of different largely used antimicrobial substances (Baratta et al., 1998; Dorman and Deans, 2000)

An interesting study evaluated the potential of Pelargonium roseum, to uptake and accumulate heavy metals like nickel $(\mathrm{Ni})$, cadmium $(\mathrm{Cd})$ or lead $(\mathrm{Pb})$; the metal content in the extracts from the entire biomass of the plant was estimated using a flame atomic absorption spectrophotometer; the results of the study indicated the efficacy of this plant for decontamination of multiple metal-polluted sites in phytoremediation industry (Mahdieh et al., 2013).

However there are no studies regarding the mineral element content of different parts of the plant. The aim of the present study was to analyze traces of elements in different parts of the plant (roots, stalks, leaves and flowers), with the purpose of demonstrating the potential for a possible use of this plant in nutritional supplements.

\section{Material and methods}

\section{Plant material cultivation and harvesting}

Cultivation of Pelargonium roseum species was carried out in the herb garden of the University of Medicine and Pharmacy from Tîrgu Mureş, Romania, on a total area of $200 \mathrm{~m}^{2}$. The harvest of the aerial parts was performed in 3 stages; in July we harvested the ramifications of stalks with 3-5 leaves, in August the ramifications of well-developed stalks and the third harvest was made at the end of the vegetation period, in September. The roots were harvested at the beginning of October. Throughout the cultivation period no herbicides or chemical fertilizers were used, because we wanted to preserve unspoiled the qualities of the essential oils obtained subsequently.

From the harvested stalks and leaves, a part was dried in order to prepare infusions and for physical and chemical determinations, and another was subject to distillation in order to obtain essential oil.

Samples from roots, lignified stems, green stalks, leafs and blooms were analyzed and the results were compared with the ones obtained from soil samples. The soil samples were taken from the cultivation zone.

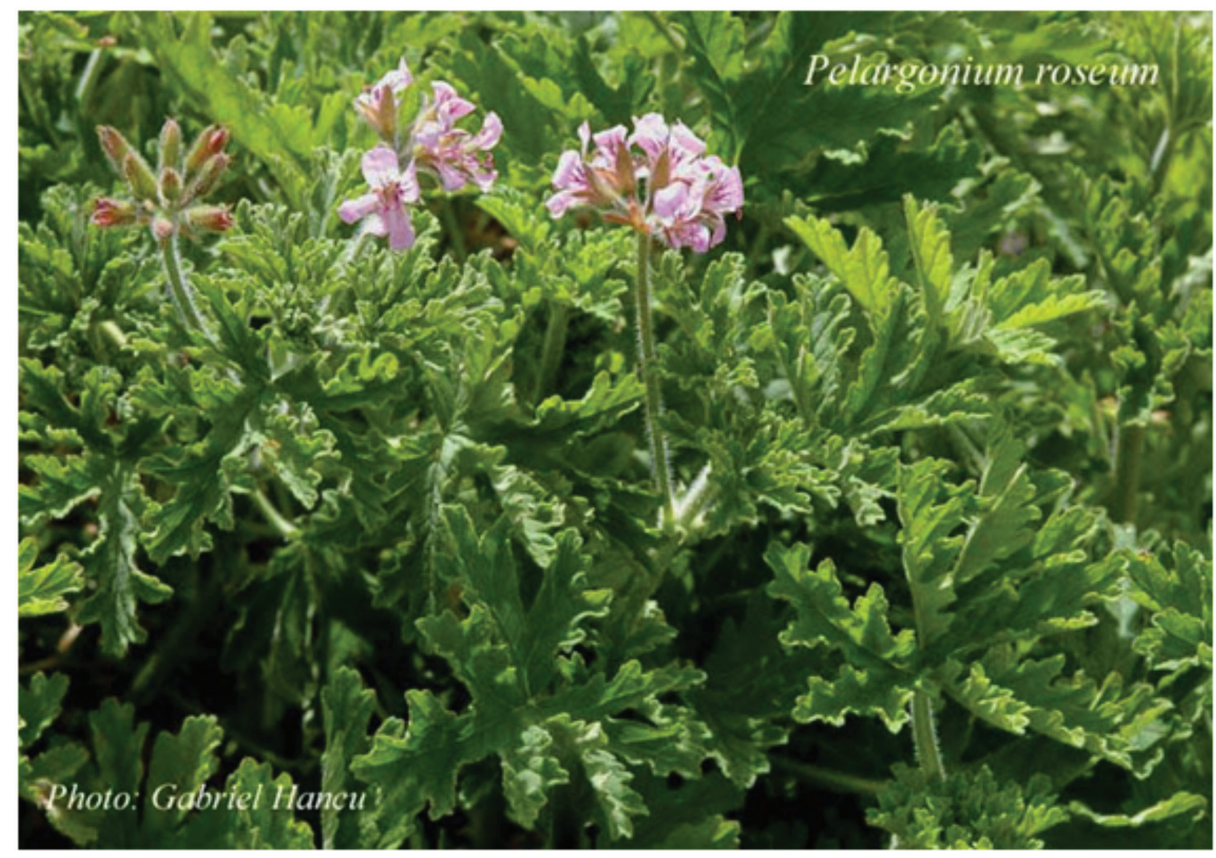

Fig. 1. Pelargonium roseum. 


\section{Reagents}

The mineral content of the plant was determined using an ICP-MS method. The technique can be used primarily for the positive ions detection. The elements whose concentration was studied were: lithium $(\mathrm{Li})$, beryllium $(\mathrm{Be})$, chromium $(\mathrm{Cr})$, manganese $(\mathrm{Mn})$, iron $(\mathrm{Fe})$, cobalt $(\mathrm{Co})$, nickel $(\mathrm{Ni})$, copper $(\mathrm{Cu})$, zinc $(\mathrm{Zn})$, gallium $(\mathrm{Ga})$, selenium $(\mathrm{Se})$, rubidium $(\mathrm{Rb})$, strontium $(\mathrm{Sr})$, silver $(\mathrm{Ag})$, cadmium $(\mathrm{Cd})$, indium $(\mathrm{In})$, barium $(\mathrm{Ba})$, thallium $(\mathrm{Tl})$, lead $(\mathrm{Pb})$ and bismuth $(\mathrm{Bi})$.

All reagents used for the microwave-assisted digestions: hydrochloric acid $(\mathrm{HCl} 36 \%(\mathrm{v} / \mathrm{v}))$, nitric acid $\left(\mathrm{HNO}_{3}\right.$ $69 \%(\mathrm{v} / \mathrm{v}))$ and hydrogen peroxide $\left(\mathrm{H}_{2} \mathrm{O}_{2} 33 \%(\mathrm{v} / \mathrm{v})\right)(\mathrm{Mer}-$ ck, Darmstadt, Germany), were of analytical grade. Highpurity water $(18 \mathrm{M} \Omega \mathrm{cm})$ obtained with a NANOpur water purification system (Barnstead D4745, Thermolyne, USA) was used for standard preparation and sample dilution. Before use, all lab utensils were thoroughly acid cleaned and then rinsed with ultrapure water. All Teflon digestion vessels were previously cleaned in a bath with $10 \%(\mathrm{v} / \mathrm{v}) \mathrm{ni}-$ tric solution for $24 \mathrm{~h}$, and then were rinsed with nanopure water, to avoid cross-contamination.

\section{Sample preparation}

The green mass subject to ICP determinations was processed by wet digestion method. The dried samples were grounded with a Mixer Grinder, and all the samples were originally stored in closed plastics bags until analysis. Samples of plant material were weighed (0.3 - $0.4 \mathrm{~g}$ / sample), introduced in teflon vessels and treated with nitric acid $(4 \mathrm{~mL})$, hydrochloric acid $(0.25 \mathrm{~mL})$ and hydrogen peroxide $(1 \mathrm{~mL})$. The vessels were then covered and left standing 24 hours under a hood, for the full decomposition of the plant material. After that the vessels were introduced in a microwave digestion apparatus for 30 minutes, where mineralization was performed in conditions of high pressure and temperature. The vessels were cooled for one hour and opened in order to evacuate the nitrogen oxides and the nitric acid. The solutions obtained through this process were transferred in calibrated tubes and filled with nanopure water to $15 \mathrm{~mL}$. A further dilution (1:10) was made in order to obtain the final samples analyzed by ICP-MS (Mihaylova et al., 2013).

The closed-vessel microwave digestion of the samples was performed with Microwave Accelerated Reaction System (Anton Paar, Multiwave 3000) (CEM, Mars 5).

\section{ICP-MS analysis}

Analysis of the samples was carried out using an ICPMS Ultramass 700 Varian system, with glass concentric nebulizer and quadropol detection. Argon (purity higher than 99.995\%) (Siad SRL, Cluj-Napoca, Romania) was used as plasma and carrier gas.

A multi-elemental ICP standard solution XXI Certi
Pur (Merck, Darmstadt, Germany), containing all the analyzed elements was used for calibration. The external calibration solutions including known concentrations of each target analyte, were prepared by diluting the stock multielement standard solution in nanopure water containing $1 \%$ nitric acid. A blank solution consisting in nanopure water containing $1 \%$ nitric acid was used for the calibration curve. The nonspectral matrix effects associated to the ICP-MS measurements were resolved by the addition of internal standards to all of the used solutions (blank, calibration and sample). The standard solution was prepared by diluting single elemental stock solutions with nanopure water containing $1 \%$ nitric acid and up to $50 \mu \mathrm{g} / \mathrm{L}$ rhodium, terbium, yttrium and scandium. The calibration coefficients for all calibration curves were at least 0.999 .

The isotopes used in this study were the following: Li7, Be-9, Cr-52, Mn-55, Fe-57, Co-65, Zn-66, Ga-71, Se78, Rb-85, Sr-88, Ag-107, Cd-111, In-115, Ba-137, Tl-205, Bi-209. The isotopes were chosen after careful evaluation of all possible isotopes, their abundances, potential interferences (meaningful in the analysis of plants) and the appropriate corrections were introduced.

The samples used for the trace element determination were prepared as follows: $1 \mathrm{~mL}$ solution obtained by wet digestion was filled with $8.70 \mathrm{~mL}$ of nanopure water and $0.1 \mathrm{~mL}$ internal standard (rhodium $4 \mu \mathrm{g} / \mathrm{l}$ and $0.2 \mathrm{~mL}$ isopropanol), thus obtaining a sample of $10 \mathrm{~mL}$. This sample solution was introduced in the apparatus using a peristaltic pump, and brought in the form of aerosol by an argon plasma nebulizer.

\section{Results and Discussion}

The results of the microelemental analysis of the vegetative parts of the Pelargonium roseum plant are presented in Table 1.

The amounts of $\mathrm{Li}, \mathrm{Be}, \mathrm{Cr}, \mathrm{Co}, \mathrm{Ga}, \mathrm{Se}, \mathrm{Ag}, \mathrm{Cd}$, In, Tl, $\mathrm{Bi}$ were quantified in $\mu \mathrm{g} / \mathrm{kg}$ while the amounts of $\mathrm{Mn}, \mathrm{Fe}$, $\mathrm{Ni}, \mathrm{Cu}, \mathrm{Zn}, \mathrm{Rb}, \mathrm{Sr}, \mathrm{Ba}, \mathrm{Pb}$ were quantified in $\mathrm{mg} / \mathrm{kg}$.

It is remarkable that the values obtained in the case of Fe analysis are significant; in green stalks Fe concentration was found to be $1.21 \mathrm{~g} / \mathrm{kg}$, whereas in leaves it was $0.66 \mathrm{~g} /$ kg (Fig. 2).

The Fe content is strongly influenced by $\mathrm{pH}$ and the redox potential of the environment, so that an alkaline soil favors Fe precipitation while an acidic soil determines its solubilization (Merian et al., 2008). The soil on which we cultivated Pelargonium roseum was a clayey soil with a $\mathrm{pH}$ of 7.63 and a Fe composition of $36.84 \mathrm{~g} / \mathrm{kg}$. The roots of the plant can be considered as Fe accumulator (11175 mg/ $\mathrm{kg}$ ), but usually $\mathrm{Fe}$ has a relatively low mobility in plant tissues. The lower content of Fe in the stem $(314.7 \mathrm{mg} / \mathrm{kg})$ and leafs $(606 \mathrm{mg} / \mathrm{kg})$ can be explained due to the involvement of $\mathrm{Fe}$ in the photosynthesis process.

The Fe daily needs of a human body is $8 \mathrm{mg}$ /day for young women and $6 \mathrm{mg}$ /day for men and for women over 
Table 1. Microelement content of the vegetative parts of Pelargonium roseum

\begin{tabular}{lccccccccccc}
\hline \hline \multirow{2}{*}{ Vegetative parts } & \multicolumn{1}{c}{ Microelement content $(\mu \mathrm{g} / \mathrm{kg})$} \\
& $\mathrm{Li}$ & $\mathrm{Be}$ & $\mathrm{Cr}$ & $\mathrm{Co}$ & $\mathrm{Ga}$ & $\mathrm{Se}$ & $\mathrm{Ag}$ & $\mathrm{Cd}$ & $\mathrm{In}$ & $\mathrm{Tl}$ & $\mathrm{Bi}$ \\
\hline Roots & 1073 & 59 & 5472 & 650 & 270 & 490 & 22 & 640 & 39 & 29 & 3 \\
Lignified stems & 59 & 36 & 744 & 221 & 31 & - & 17 & 199 & 2 & 9 & 6 \\
Green stalks & 80 & 50 & 940 & 119 & 45 & 424 & 10 & 164 & 8 & 9 & 150 \\
Leafs & 267 & 25 & 1584 & 1232 & 79 & - & 98 & 8 & 23 & 20 & 7 \\
Blooms & 227 & 161 & 1974 & 493 & 96 & 4161 & - & 20 & 12 & 40 & 45 \\
\hline
\end{tabular}

\begin{tabular}{lccccccccc}
\hline \multirow{2}{*}{ Vegetative parts } & \multicolumn{8}{c}{ Microelement content (mg/kg) } \\
& $\mathrm{Mn}$ & $\mathrm{Fe}$ & $\mathrm{Ni}$ & $\mathrm{Cu}$ & $\mathrm{Zn}$ & $\mathrm{Rb}$ & $\mathrm{Sr}$ & $\mathrm{Ba}$ & $\mathrm{Pb}$ \\
\hline Roots & 40.8 & 1175.6 & 3.5 & 19.7 & 62.5 & 5.4 & 74.1 & 24.8 & 156.5 \\
Lignified stems & 29.7 & 314.7 & 1.1 & 6.2 & 74.6 & 2.5 & 30.8 & 11.7 & 1 \\
Green stalks & 39.4 & 1213.9 & 1.2 & 4.5 & 54.9 & 6 & 54.8 & 11.2 & 0.8 \\
Leafs & 53.3 & 606 & 2.1 & 4.8 & 31.5 & 3.2 & 40.2 & 16.1 & 5.5 \\
Blooms & 45.7 & 967.2 & 2.2 & 8.3 & 42.2 & 4.8 & 36.3 & 28.5 & 3 \\
\hline
\end{tabular}

50 years, therefore vegetative parts of Pelargonium rosuem can be a valuable source of Fe.

Amounts comparable with those found in the soil were found for $\mathrm{Sr}$; as the roots contained a quantity of $\mathrm{Sr}$ (74.1 $\mathrm{mg} / \mathrm{kg}$ ), which exceeded the quantity found in the soil (54.82 mg/kg) (Fig. 3).

Previous studies show a correlation between the ratio of $\mathrm{Sr}$ and $\mathrm{Ca}$ from plants, both elements being taken up from soil in similar proportions. Although $\mathrm{Ca}$ was not determined from the vegetative parts of the plant, being present over the concentration range on which the determination was made; traces of $\mathrm{Ca}$ have been found at a morphological examination of the plant when calcium oxalate crystals were revealed (especially in roots). To date there are no eloquent studies regarding the essentiality of $\mathrm{Sr}$ for plants, animals or people (Merian et al., 2008).

Mn plays an essential part in plant metabolism, its function being correlated with redox processes when changes its valence from $\mathrm{Mn}^{2+}$ to $\mathrm{Mn}^{4+}$. It plays an important role in the photosynthesis process, both as oxygen generator and participating in the electronic transport associated to this process (Merian et al., 2008).

The active role, which Mn plays in photosynthesis, explains its presence in high quantities in leafs $(53.3 \mathrm{mg} / \mathrm{kg})$; while the smaller quantities were identified in the stems $(29.7 \mathrm{mg} / \mathrm{kg})$, where the presence of chlorophyll is low-

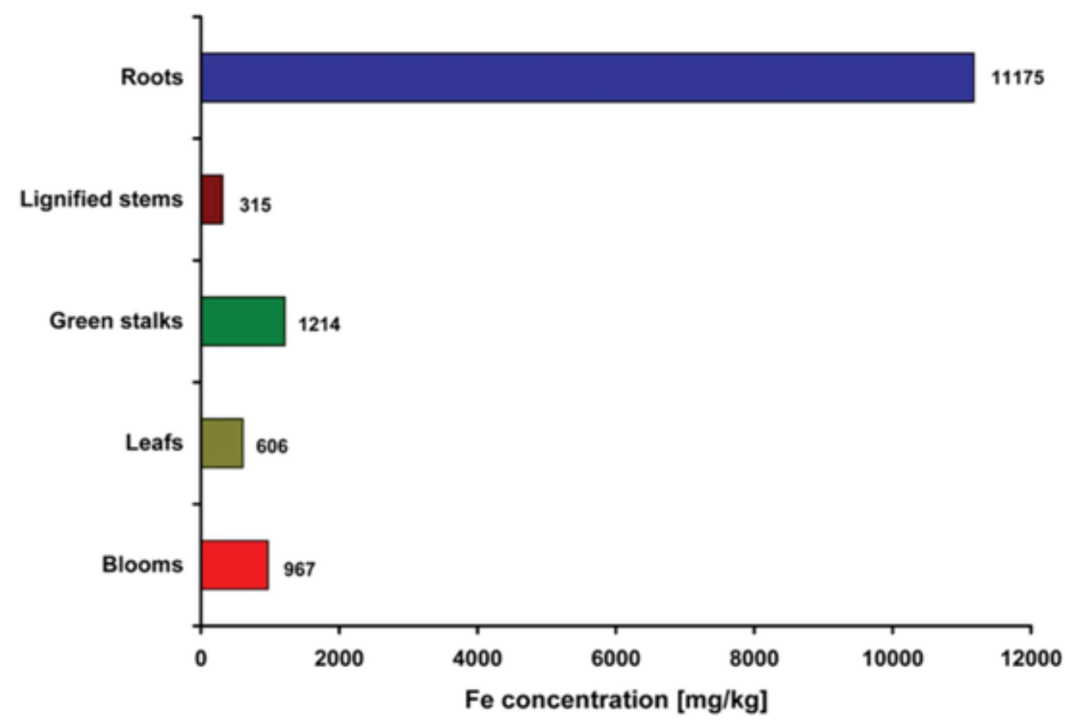

Fig. 2. Fe concentration in different vegetative parts of Pelargonium roseum. 


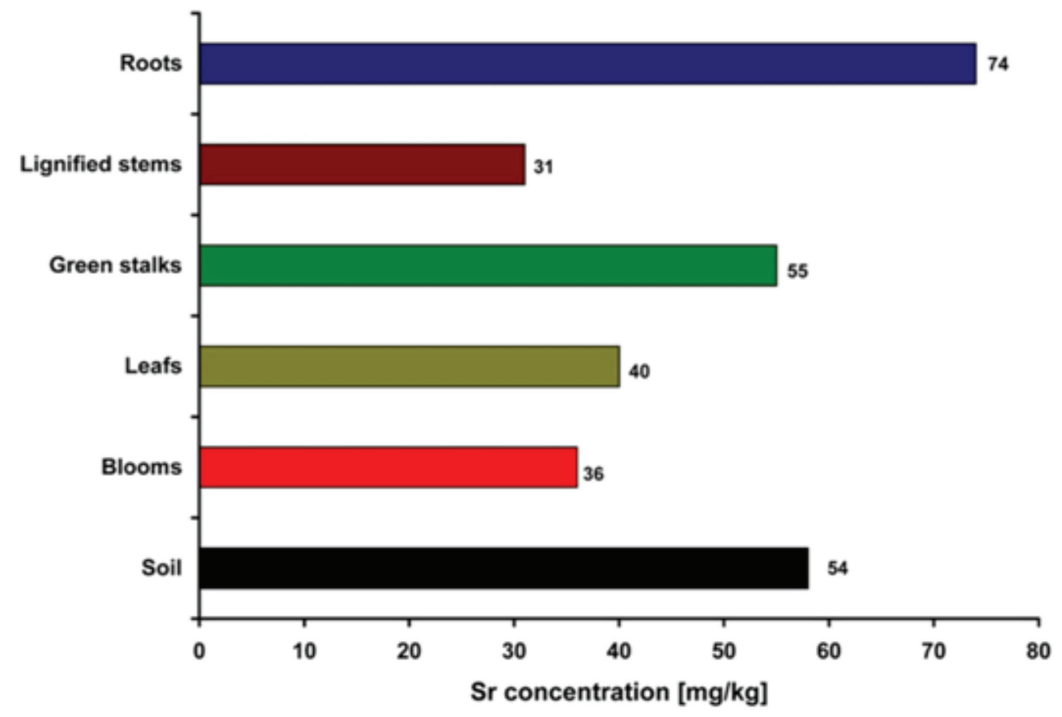

Fig. 3. Sr concentration in different vegetative parts of Pelargonium roseum.

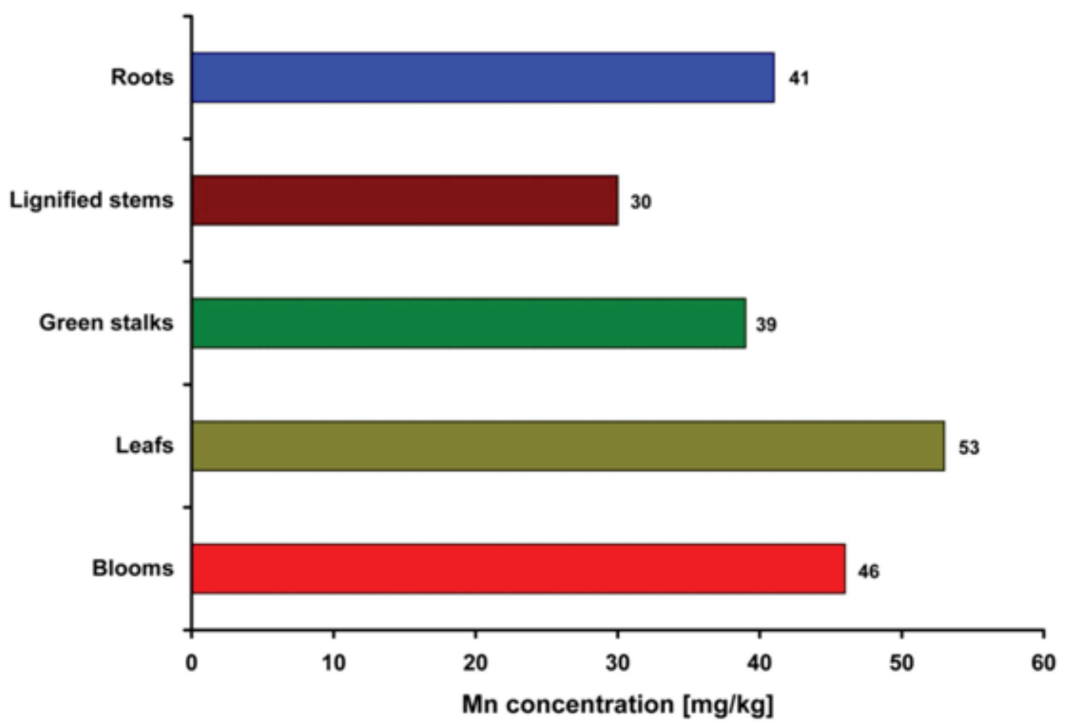

Fig. 4. Mn concentration in different vegetative parts of Pelargonium roseum.

er (Fig. 4).

Mn plays an important role in human metabolism as constituent and activator of different enzymatic systems. The Mn daily need of the human body is between $2-5 \mathrm{mg} /$ day, therefore vegetative parts of Pelargonium rosuem can be a source of Mn.

Relatively high concentrations of $\mathrm{Zn}$ were found in the vegetative parts of the plant, the highest concentrations were found in stems $(74.6 \mathrm{mg} / \mathrm{kg})$ and roots $(62.5 \mathrm{mg} / \mathrm{kg})$ in comparison with the soil content (170 mg/kg) (Fig. 5).

$\mathrm{Zn}$ is considered an essential element for living organisms, entering in the composition of more than 300 enzyme and proteins, which take part in all major metabolic pro- cesses. ${ }^{9}$ The $\mathrm{Zn}$ daily needs of a human body is $4.6 \mathrm{mg} /$ day for men and $3.8 \mathrm{mg} /$ day for women, therefore Pelargonium roseum can be useful in completing the daily needs of $\mathrm{Zn}$.

High quantities of Se were found in the blooms (4161 $\mu \mathrm{g} / \mathrm{kg})$ in comparison with soil $(490 \mu \mathrm{g} / \mathrm{kg}$ ) (Fig. 6). The Se content from soil is not direct proportional with its biodisponibility towards plants (Merian et al., 2008).

Se is involved in various enzymatic mechanisms, having also a protective role against toxins and carcinogens from the environment. The Se daily needs of a human body is around $20 \mu \mathrm{g} /$ day; excepting its blooms Pelargonium roseum contains relatively small amounts of $\mathrm{Se}$; but it should be noted that Se biodisponibility in the case of 
plants is much higher to that of the nutritional supplements, which recommends medicinal plants usage in order to supplement the shortage of this element (Merian et al., 2008).

The content of $\mathrm{Li}, \mathrm{Rb}, \mathrm{Be}, \mathrm{Ba}, \mathrm{Cr}, \mathrm{Co}, \mathrm{Ni}, \mathrm{Cu}, \mathrm{Cd}, \mathrm{Pb}$, $\mathrm{In}, \mathrm{Tl}$ in the vegetative parts of the plant were much lower than their content in the soil.

All concentrations were within the recommended daily allowance (RDA) limits. RDA, the average daily dietary intake level, is expected to be sufficient to meet the nutrient requirements of all healthy individuals (World Health Organization, 1991; World Health Organization, 1998).

Human dietary micronutrients are required by humans in very small amounts, including at least 14 trace elements (As, B, Cr, Cu, F, I, Fe, Mn, Mo, Ni, Se, Si, V, Zn). The rec- ommended daily intake of the micronutrient trace elements is of the order of: mg per day for $\mathrm{B}, \mathrm{Cu}, \mathrm{F}, \mathrm{Fe}, \mathrm{Mn}, \mathrm{Zn}$ and $\mu \mathrm{g}$ per day for As, Cr, I, Mo, Ni, Se, Si, V.

These results, therefore, would suggest that consumption of Pelargonium roseum powder can provide users with some of the essential minerals that the human body requires for optimum function.

\section{Conclusions}

The knowledge of the elemental composition of plants is important for a variety of scientific areas - plant physiology, agriculture, environmental monitoring, medicine or

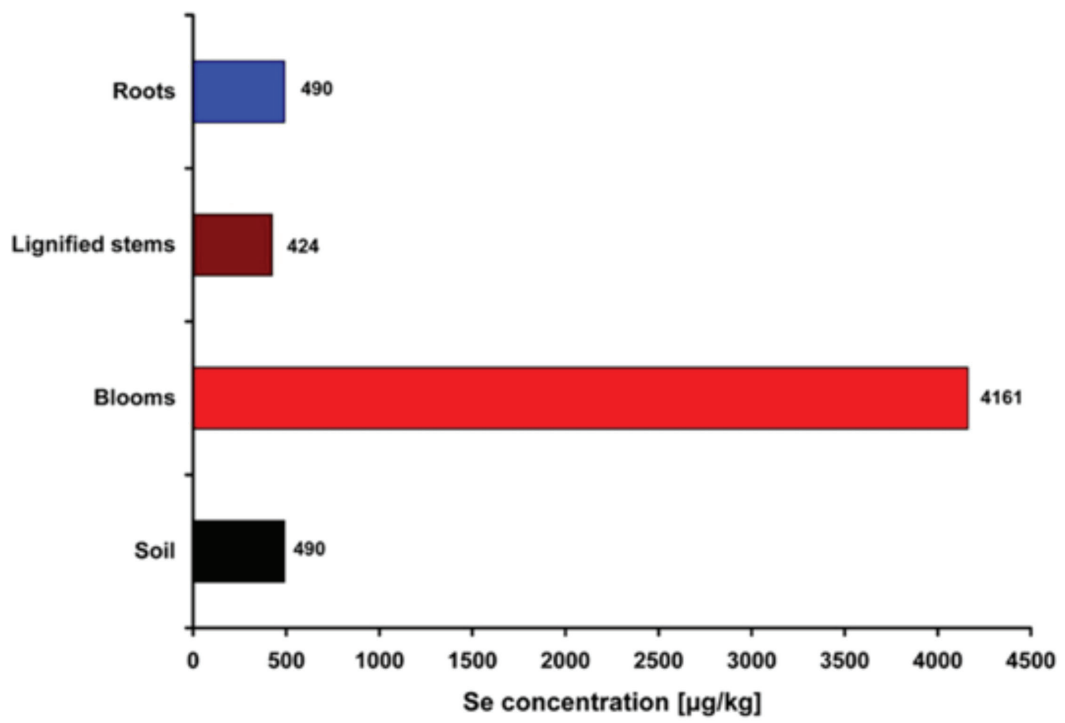

Fig. 5. Zn concentration in different vegetative parts of Pelargonium roseum.

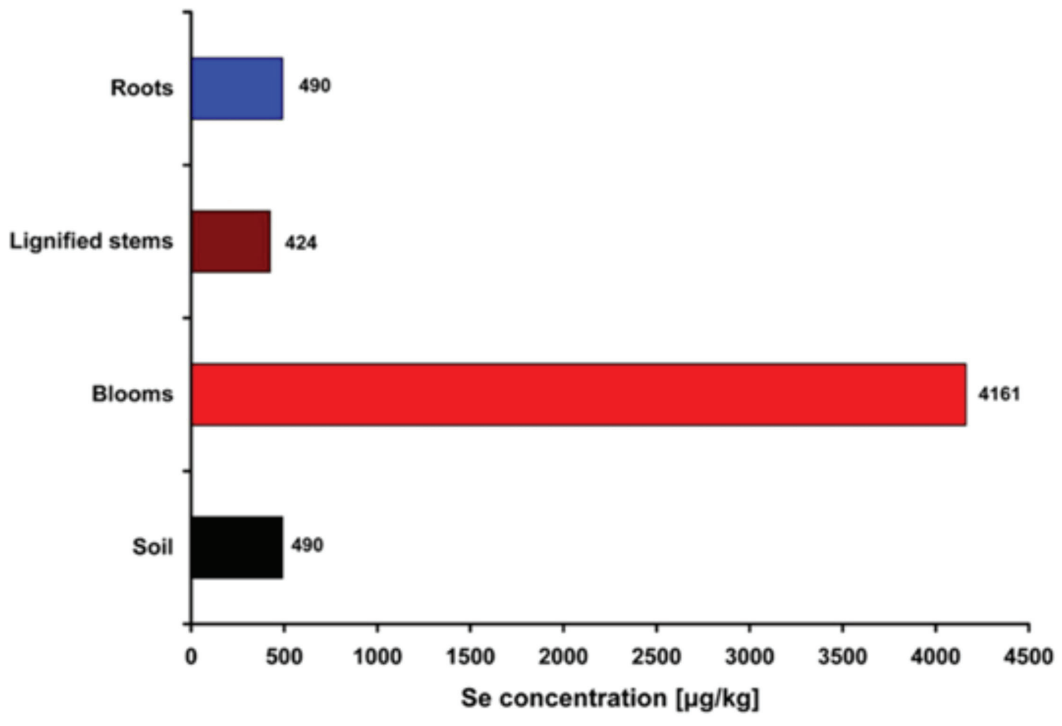

Fig. 6. Se concentration in different vegetative parts of Pelargonium roseum. 
pharmacy; as plants usually uptake nutrients and also toxic substances from soil, water and air.

Considering the results of our ICP-MS analysis Pelargonium roseum can be useful source of $\mathrm{Mn}, \mathrm{Zn}$ and especially Fe. The ICP technique was well suited for the multielemental analysis of vegetable samples in order to ascertain the nutritional role of medicinal plants and the daily dietary intake.

Taking in consideration the high content of Fe of certain vegetative parts of Pelargonium roseum, and the fact that people's need of $\mathrm{Fe}$ is not entirely satisfied through nourishment, Pelargonium roseum might be used in order to supplement Fe input.

Another advantage can be the fact that Pelargonium roseum is a plant rich in $\mathrm{Fe}$ and with reduced tannin content; consequently the biodisponibility of Fe is not impeded. All these aspects are arguments for a possible use of a capsule which contains powder obtained from this plant as a nutritional supplement in case of iron deficiency.

It must, however, be stated that, because plants may absorb elements from the soil and environment, some of which may be toxic to humans, plant nutrition, climate, and soil conditions and locations could also determine the elemental contents.

Our results are a contribution to a better valorization of this medicinal plant. However further studies will be worthwhile to be performed to confirm the safety of these potential products as dietary supplements, to characterize active principles, and assess toxicity by laboratory assays.

\section{References}

Baratta, M.T., Dorman, H.J., Deans, S.G., Figueiredo, A.C., Barroso, J.G., Ruberto, G., 1998. Antimicrobial and antioxidant properties of some commercial essential oils.
Flavour Frag. J. 13, 235-244.

Cavar, S., Maksimovic, M., 2012. Antioxidant Activity of Essential Oil and Aqueous Extract of Pelargonium graveolens L'Her. Food Control. 23, 263-267.

Dorman, H.J.D., Deans, S.G., 2000. Antimicrobial agents from plants: antibacterial activity of plant volatile oils. J. Appl. Microbiol. 88, 308-316.

Dzamic, A.M., Sokovic, M.D., Ristic, M.S., Grujic, S.M., Mileski, K.S., Marin, P.D., 2014. Chemical composition, antifungal and antioxidant activity of Pelargonium graveolens essential oil. J. Appl. Pharm. Sci. 4(3), 1-5.

Lancu, C.E., Cioanca, O., Mircea, C., Hăncianu, M., 2013. Contributions regarding leaf histo-anatomy of some Pelargonium species. Rev. Med. Chir. Soc. Med. Nat. Iași. 117(3), 812-818.

Lis-Balchin, M., Deans, S.G., Hart, S., 1996. Bioactivity of commercial Geranium oil from different sources. J. Essent. Oil. Res. 8, 281-290.

Mahdieh, M., Yazdani, M., Mahdieh, S., 2013. The high potential of Pelargonium roseum plant for phytoremediation of heavy metals. Environ. Monit. Assess. 185: 7877-7881.

Mihaylova, V., Lyubomirova, V., Djingova, R., 2013. Optimization of sample preparation and ICP-MS analysis for determination of 60 elements for characterization of the plant ionome. Intern. J. Environ. Anal. Chem. 93(3), 14411456.

Merian, E., Anke, M., Ihnat, M., Stoeppler, M., 2008. Elements and their compounds in the environment: occurrence, analysis and biological relevance, $2^{\text {nd }}$ ed., Wiley $\mathrm{VCH}$ Verlag, Weinheim.

Moyo, M., van Staden, J., 2014. Medicinal properties and conservation of Pelargonium sidoides DC. J. Ethnopharmacol. 152(2), 243-55.

World Health Organization. Guidelines for the Assessment of Herbal Medicines WHO/TRM/91.4. Geneva, Switzerland: WHO.1991.

World Health Organization. Quality Control Methods for Medicinal Plant Materials.Geneva, Switzerland: WHO. 1998. 
Резиме

\title{
Определување на содржина на минерали во Pelargonium roseum со примена на ICP-MS
}

\author{
Кармен Галеа ${ }^{1}$, Габриел Ханку² ${ }^{*}$, Атила Цизер ${ }^{3}$, Ценгеле Моника Јеженски ${ }^{4}$, \\ Енико Барабаз ${ }^{5}$

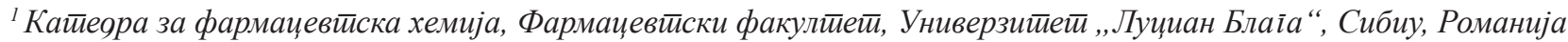

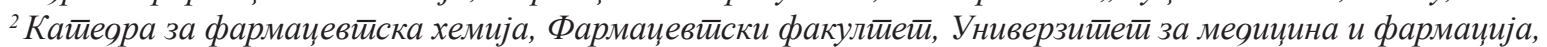 \\ Tиріу Мурес, Романија \\ ${ }^{3}$ Национален Инстиитиут̄ за Јавно зоравје, Тиріо Мурес, Романија \\ ${ }^{4}$ Меоицински факулитет̄, Универзитетет̄ за меоицина и фармаџија, Тиріуу Мурес, Романија \\ ${ }^{5}$ Кайеора за ботианика и клейочна биолоіија, Фармацевйски факулйей, Универзииети за меоицина и фармација, \\ Tuріу Мурес, Романија
}

Клучни зборови: Pelargonium roseum, анализа на микроелементи, ICP-MS, додатоци во исхрана

Содржината на микроелементите во различни вегетативни органи на Pelargonium roseum е испитувана со метод на индуктивно спрегната плазма - масена спектрометрија (ICP-MS). Аналитичкиот метод овозможи определување на 20 елементи (Li, Be, Cr, Mn, Fe, Co, Ni, Cu, Zn, Ga, Se, Rb, Sr, Ag, Cd, In, Ba, Tl, Pb, Bi). Примероците од различни вегетативни органи (корени, лигнифицирани стебла, зелени стебленца, листови, пупки) се анализирани и споредени со примероци на почва. Вегетативните органи на растението содржат значителни количини на манган, зинк и особено железо. Добиените резултати можат да бидат мошне корисни за определување на препорачана доза на делови од растението (растителни органи) за употреба во медицински растителни производи со оглед на неговата нутритивна вредност и фармаколошките функции. 


\title{
Influence of oligofructose-enriched inulin on survival of microencapsulated Lactobacillus casei 01 and adhesive properties of synbiotic microparticles
}

\author{
Tanja Petreska Ivanovska ${ }^{1 *}$, Zoran $Z_{\text {hivikj }}{ }^{1}, K_{\text {ristina Mladenovska }}^{2}$, \\ Lidija Petrushevska-Tozi ${ }^{1}$ \\ ${ }^{1}$ Institute of Applied Biochemistry, Faculty of Pharmacy, University "Ss. Cyril and Methodious", \\ Mother Theresa 47, Skopje, Macedonia \\ ${ }^{2}$ Institute of Pharmaceutical Technology, Faculty of Pharmacy, University "Ss. Cyril and Methodious", \\ Mother Theresa 47, Skopje, Macedonia
}

Received: March 2015; Accepted: April 2015

\begin{abstract}
Lactobacillus casei 01 was co-encapsulated with the prebiotic oligofructose-enriched inulin at different concentrations to investigate the efficiency of the prebiotic for improving the probiotic viability. Prebiotic effect on the probiotic survival under microencapsulation conditions by spray- and freeze-drying and storage stability of encapsulated living cells at $4{ }^{\circ} \mathrm{C}$ during period of 8 weeks was evaluated. Adhesiveness of $L$. casei 01 loaded microparticles to pig mucin was investigated in vitro to estimate the role of microencapsulation for improving the cell adhesion ability. The microparticles produced with $3 \% w / w$ oligofructose-enriched inulin showed higher initial count, while oligofructose-enriched inulin applied at $1.5 \% \mathrm{w} / \mathrm{w}$ resulted in better protection of $L$. casei 01 under storage conditions. Further, it has been observed significantly increased pig mucin binding to microparticles compared to free probiotic cells in buffer solutions simulating GI conditions, during $24 \mathrm{~h}$ incubation. Hence, cell microencapsulation beside enhanced viability may allow prolonged residence time of the probiotic cells in the lower intestine through excellent muco-adhesive properties of the encapsulating materials. The results suggest synbiotic chitosan-Ca-alginate microparticles as convenient delivery system capable to ensure effective cell concentration in the lower intestine where probiotic colonization is dominant.
\end{abstract}

Keywords: oligofructose-enriched inulin, Lactobacillus casei, synbiotic microparticles, muco-adhesion

\section{Introduction}

Functional foods containing naturally or added probiotics and/or prebiotics provide physiological or metabolic benefits by regulating the gut microbiota composition and stability. The health-beneficial properties of these bioactive compounds have made functional foods increasingly popular in food markets (Peshev and Van den Ende, 2014).

* Tel.: +3892 3123062; fax: +38923123054

tpetreska@ff.ukim.edu.mk
Probiotics that belong mainly to the genera Lactobacillus and Bifidobacterium can alter the microbial balance aiding the host through several mechanisms, such as production of pathogen-inhibitory substances, competition with pathogenic bacteria for epithelial adhesion sites, nutrient competition and production, degradation of toxins and toxin receptors and modulation of immune and nonspecific host responses (Prakash et al., 2011). Examples of health benefits attributed to probiotics range from treatment of Helicobacter pylori infections (Gotteland et al., 2008) and antibiotic-associated diarrhea (Marteau et al., 
2001), inflammatory bowel diseases (Gentschew and Ferguson, 2012), irritable bowel syndrome (Almansa et al., 2012), allergic diseases such as eczema and atopic dermatitis (Wickens et al., 2008), delaying of aging in humans (Duncan and Flint, 2013), modulating blood lipid levels (Omar et al., 2013) to prevention of gastrointestinal cancers (Orlando and Russo, 2012).

The most important aspect of a probiotic to provide its health benefits is to remain viable during processing and storage of food products and also after consumption. The final probiotic product that serves as a probiotic delivery system should contain at least $10^{6}-10^{7}$ live microorganisms per $\mathrm{g}$ or $\mathrm{mL}$ before consumption (Nualkaekul et al., 2012). Viability loss may be reduced by immobilization or microencapsulation of probiotic bacteria in a polymer matrix (Mitropoulou et al., 2013). Along with survival, binding of probiotic bacteria to intestinal cells is often the main feature studied. Adhesion to the intestinal epithelium is an outcome property of probiotics that may influence the residence time of the bacteria in the intestinal tract (MuñozProvencio et al., 2009) and is considered to be associated with documented health effects for the host. Binding of microbial cell-surface molecules to the mucus layer is possible mechanism of bacterial adherence based on non-specific physical interactions which then enable specific interactions between proteins and mucin-bound oligosaccharides (Van Tassell and Miller, 2011). Adhesive characteristics of lactobacilli vary considerably among strains and species depending on physicochemical structure of the cell membrane, conformation of cell surface macromolecules and susceptibility to external factors (Deepika and Charalampopoulos, 2010). Hence, microencapsulation using polymer materials with convenient biochemical properties may contribute to improved physicochemical characteristics of the cell i.e. muco-adhesion along with improved cell survival. Hydrophilic polymers such as alginate and chitosan possess favorable muco-adhesive properties providing enhanced in situ delivery of probiotic bacteria in the gastrointestinal tract (Chen et al., 2013).

Prebiotic supplementation to probiotic products or formulations may potentially be useful for enhancing the probiotic survival during processing (Corcoran et al., 2004) and storage (Capela et al., 2006). Prebiotics are defined as "selectively fermented ingredients that result in specific changes in the composition and/or activity of the gastrointestinal microbiota, thus conferring benefit upon host health" (ISSAP, 2008). They pass through the upper gastrointestinal tract undigested, entering the large bowel where can influence the growth of microbial populations and the production of short chain fatty acids (SCFAs) (Macfarlane et al., 2006). Acetate, propionate and butyrate, as the main SCFAs, and lactate, as an important intermediate in the formation of SCFAs, are thought to be beneficial to host health. They have been found to alter gut integrity and to possess anti-inflammatory, antimicrobial and anti-carcinogenic effects, thus playing significant role in maintenance of gut and immune homeostasis (Tan et al., 2014). The most widely studied prebiotics which can be selectively used by bifidobacteria and lactobacilli as substrates are fructooligosaccharide (FOS), galacto-oligosaccharide (GOS) and inulin (Watson et al., 2013). Inulin as polysaccharide and FOS as oligosaccharide are naturally occurring inulin type fructans with similar structure build up of $\beta 2 \rightarrow 1$ linkages. These carbohydrates have generally been distinguished by the polymerization level, while oligofructose and FOS are products of the inulin hydrolysis.

A selective inclusion of probiotic and prebiotic in accordance with the desired health effects would provide an effective synbiotic. The presence of the prebiotic compound may improve the probiotic survival during processing and storage of the products and also after consumption. Co-encapsulation of probiotics, L. rhamnosus, L. acidophilus, L. casei and Bifidobacterium spp. with prebiotics such as FOS (Raftilose P95) improved their viabilities at $4{ }^{\circ} \mathrm{C}$ for 4 weeks of product storage (Capela et al., 2006). Freshcut apple wedges with synbiotic properties and counts of probiotic bacteria comparable to commercially available dairy products (ca. $10^{8} \mathrm{cfu} / \mathrm{g}$ ) have been developed using L. rhamnosus $\mathrm{GG}$ as probiotic and inulin and oligofructose as prebiotics (Rößle et al., 2010). Application of prebiotics as co-components for microencapsulation of probiotics or immobilization of probiotics in prebiotic edible films has also conferred a beneficial effect on cell viability (Nazzaro et al., 2009; Fritzen-Freire et al., 2012; Krasaekoopt and Watcharapoka, 2014; Petreska Ivanovska et al., 2014a; Sathyabama et al., 2014; Soukoulis et al., 2014). Although, significant number of synbiotic combinations confirms the synergistic effect of the prebiotic in enhancing probiotic survival and growth in vitro and in vivo, literature evidences are still limited (Duncan and Flint, 2013).

Our previous investigations (Petreska Ivanovska et al., 2012b; 2014a) indicated that the applied spray-drying method and combination of chitosan and alginate crosslinked with $\mathrm{CaCl}_{2}$ as protective agents in presence of $\mathrm{FOS}$ from chicory (DP > 10) $(1.5 \% \mathrm{w} / \mathrm{w})$ efficiently preserved the viability of $L$. casei 01 during encapsulation, cold storage and in simulated gastrointestinal conditions. In the present study, we examined the influence of the prebiotic oligofructose-enriched inulin (Synergy 1) on the viability of encapsulated $L$. casei 01 during microencapsulation by spray-drying and subsequent cold storage during 8 weeks. In addition, adherence capacity of the L. casei 01 loaded microparticles containing Synergy 1 in concentration showing better effect on the probiotic viability was studied in vitro.

\section{Materials and methods}

\section{Materials}

Freeze-dried probiotic culture of Lactobacillus paracasei subsp. paracasei with commercial name FD-DVS 
Lactobacillus casei 01 was purchased from Chr. Hansen, Denmark. The prebiotic, oligofructose-enriched inulin (Orafti ${ }^{\circledR}$ Synergy 1) which is the mixture of oligofructose (DP 2-8) and long-chain inulin fraction (DP 1060) was supplied from Orafti-Rue L. Maréchal, Tienen, Belgium. Sodium alginate (Protanal LF 10/60 LS, fG 35$45 \%$ ), which was kindly donated by IMCD, FMC BioPolymer (Ayrshire, UK), was used as an encapsulating agent for manufacturing of L. casei 01 loaded microparticles. Chitosan with deacetylation degree $\geq 85 \%$ and low viscosity 342 (viscosity of $1 \% \mathrm{v} / \mathrm{v}$ solution in acetic acid 20-100 $\mathrm{mPa} s, \mathrm{M}_{\mathrm{w}} 150 \mathrm{kDa}$ (France Chitine, Marseille, France) was used for coating of spray-dried microparticles, while the cross-linking procedure was performed with $\mathrm{CaCl}_{2}$ (Merck, KGaA, Darmstadt, Germany). The Man Rogosa Sharpe (MRS) broth, MRS agar and peptone water used for growth and enumeration of $L$. casei 01 were purchased from Merck, KGaA, Darmstadt, Germany. Pig mucin (Mucin from porcine stomach, Type II, bond sialic acids: $1 \%$ ) used for in vitro determination of adherence properties of L. casei 01 and prepared microparticles was supplied from Sigma-Aldrich, Co., St. Louis, USA.

\section{Preparation of probiotic culture}

Freeze-dried culture of $L$. casei 01 was inoculated in $10 \mathrm{~mL}$ MRS broth at $37^{\circ} \mathrm{C}$ under aerobic conditions overnight to reach the cell concentration at least $12 \log \mathrm{CFU}$ $\mathrm{mL}^{-1}$. The next day, cells were harvested by centrifugation at $1500 \mathrm{~g}$ for $10 \mathrm{~min}$ and washed with sterile peptone water $(0.1 \% w / v)$.

\section{Microencapsulation of probiotic and prebiotic}

Probiotic/synbiotic chitosan-Ca-alginate microparticles were prepared according to the method described by Petreska-Ivanovska et al. (2014a). The feed suspension was prepared of carrier agent sodium alginate $(4 \% \mathrm{w} / \mathrm{w})$ and previously prepared probiotic suspension. To produce synbiotic microparticles, to the probiotic-alginate dispersion, the prebiotic, oligofructose-enriched inulin at respective concentrations of $0,1.5,3$, and $5 \% w / w$, was added. Then, the mixture was spray-dried (Büchi Mini Spray Dryer B-290, Flawil, Switzerland) at following conditions: constant air inlet temperature of $120{ }^{\circ} \mathrm{C}$ and outlet temperature at $58 \pm 3{ }^{\circ} \mathrm{C}$, flow rate $6 \mathrm{ml} / \mathrm{min}$, nozzle diameter $0.7 \mathrm{~mm}$, aspirator pressure $90 \%$ and atomizer pressure $600 \mathrm{Nlh}^{-1}$. Dried powder samples were slowly added to a $5 \% \mathrm{w} / \mathrm{w} \mathrm{CaCl}_{2}$ and $0.5 \% \mathrm{w} / \mathrm{w}$ chitosan dissolved in $1 \% \mathrm{v} / \mathrm{v}$ acetic acid, under continuous stirring. The microparticles were allowed to stir on a magnetic stirrer for at least $3 \mathrm{~h}$ at $25{ }^{\circ} \mathrm{C}$. Then, the particles were separated by centrifugation at $1500 \mathrm{x} g$ for $10 \mathrm{~min}$, rinsed with sterile saline solution and then freeze-dried at $0.070 \mathrm{mbar}$ and $-50{ }^{\circ} \mathrm{C}$ for 24 h (FreeZone Freeze Dry System, Labconco, Kansas City, USA).

\section{Enumeration of encapsulated L. casei 01}

Viability of encapsulated and co-encapsulated L. casei during microencapsulation and in storage conditions was determined using plate-count method. One gram of particles was suspended in $9 \mathrm{~mL}$ phosphate buffer solution $(\mathrm{pH}$ 6.9) at room temperature and then allowed to stand until complete release of the probiotic cells. Then, sequential dilutions were prepared using $0.1 \% \mathrm{w} / \mathrm{v}$ peptone water in order to achieve countable cell numbers. Quantitative determination of viable cells was performed on selective MRS agar after $72 \mathrm{~h}$ aerobic incubation at $37^{\circ} \mathrm{C}$. Enumeration of viable cells was performed in triplicates counting the plates with 30-300 colonies and the average of the results was expressed as colony-forming units (CFU) per $\mathrm{g}$ of sample. The obtained results calculated in $\mathrm{CFU} \mathrm{\textrm {g } ^ { - 1 }}$ were converted to $\log \mathrm{CFU} \mathrm{g}^{-1}$.

In vitro analysis of the adhesive properties of L. casei 01 and synbiotic loaded microparticles

Adherence capacity of L casei 01 cells, synbiotic and empty microparticles was tested by in vitro adsorption studies using pig mucin (PM) in accordance to the method described by Glavas Dodov et al. (2009). To determine the bioadhesive interactions of the free cells, synbiotic and empty microparticles, $5 \mathrm{~mL}$ of the pig mucin suspension was mixed with the equal volume of cell or microparticle suspension and incubated in different buffer solutions $(\mathrm{pH}$ 2.0, 4.5, 6.8, and 7.4; Ph.Eur. 4). After 1, 3, 5, and $24 \mathrm{~h}$ incubation at $37{ }^{\circ} \mathrm{C}$, the samples were centrifuged $(10 \mathrm{~min}$ at $4000 \mathrm{rpm}$ ), and the remaining free PM in the supernatants was measured UV spectrophotometrically (Perkin Elmer UV/VIS Spectrometer, Lambda 16, Arizona, USA) at $251 \mathrm{~nm}$, since interacted PM was sediment with the cells or particles. The PM binding efficiency of cells or microparticles was calculated using following equation:

$$
\text { PM binding efficiency }(\%)=(\mathrm{Co}-\mathrm{Cs}) / \mathrm{Co} \times 100
$$

Where Co is the initial concentration of PM used for incubation and $\mathrm{Cs}$ is the concentration of free PM determined in the supernatant.

\section{Data analysis}

Mean values of the obtained results were analyzed by two-way ANOVA at a significance level of $p<0.05$.

\section{Results and discussion}

Influence of Synergy 1 on the survival of L. casei 01 during microencapsulation

High temperature, presence of oxygen and high osmotic pressure associated with the drying processes are detrimental for living cells survival (Meng et al., 2008). 
Hydrocolloids as oligosaccharides are might preserve cell viability, allowing hydrogen binding and preventing cell proteins from denaturation (Capela et al., 2006). In order to improve the probiotic survival during microencapsulation, in this study an oligofructose-enriched inulin Synergy 1 was used to co-encapsulate $L$. casei 01 in chitosan-Caalginate microparticles prepared by spray-drying and subsequent freeze-drying. The effect of the prebiotic Synergy 1 on the survival of $L$. casei 01 during microencapsulation when added at concentrations of $1.5,3$, and $5 \% \mathrm{w} / \mathrm{w}$ to a previously optimized formulation of chitosan-Ca-alginate microparticles (Petreska Ivanovska et al., 2014a) was examined and the data are presented in Fig. 1. In a previous study in which survival rate of $L$. casei after co-encapsulation with the prebiotic FOS was studied, used in the same concentrations as Synergy 1, relatively high viability of 11.1-11.2 $\log \mathrm{CFU} \mathrm{g}^{-1}$ after microencapsulation was observed (Petreska Ivanovska et al., 2012b). However, FOS was reported to be less stable oligosaccharide under conditions of low $\mathrm{pH}$ and high temperatures, especially if two factors are combined (Charalampopoulos and Rastall, 2012). For this reason, the prebiotic oligofructose-enriched inulin was used to co-encapuslate $L$. casei 01 and the data related to the probiotic viability after preparation of microparticles and during cold storage were compared. Comprising that oligosaccharides with low degree of polymerization (DP 6-10) are more acceptable by bacteria (Sathyabama et al., 2014), Synergy 1, being a mixture of oligofructose with DP 2-8 and long-chain inulin fraction (DP 10-60), was expected to provide better protection than FOS from chicory (DP $>10)$.

The results obtained pointed that probiotic survival during preparation of the microparticles in the presence of oligofructose-enriched inulin was significantly enhanced $(\mathrm{p}<0.05)$. However, the results for survival rate of $L$. case $i$ 01 in a presence of $1.5-5 \% w / w$ oligofructose-enriched inulin ranging from 11.31-11.38 $\mathrm{log} \mathrm{CFUg}^{-1}$ showed no significant difference $(\mathrm{p}>0.05)$ compared to those of the respective FOS levels, ranging from 11.28-11.33 log CFUg${ }^{1}$. This finding may be explained by the similar structure of both prebiotics. Namely, in a study of Fritzen-Freire and co-workers (Fritzen-Freire et al., 2012), microencapsulated Bifidobacterium BB-12 showed higher initial count (after spray-drying) with encapsulating agent reconstituted skim milk (RSM) and prebiotics inulin or oligofructoseenriched inulin in a ratio $1: 1$, when compared to microcapsules produced with RSM only and with oligofructose. The inulin was reported to act as a thermoprotector for the cells undergoing the drying process. Inulin applied at concentration of $0.5,1$, and $1.5 \%$ was also reported to provide improved survival during microencapsulation of $L$. acidophilus 5 and $L$. casei 01 with alginate and chitosan (Krasaekoopt and Watcharapoka, 2014). However, in the study, an extrusion technique was used to encapsulate the cells. Also, viability of L. rhamnosus GG during air drying was significantly enhanced by glucose-oligosaccharides and polydextrose, whilst inulin was the most effective to control the sub-lethal effects on the cells during storage of prebiotic edible films developed as vehicles for encapsulated L. rhamnosus GG (Soukoulis et al., 2014). Cell viability upon thermal processes is strongly influenced not only by extrinsic factors, but also intrinsic factors such as tolerance of the strain to heat, osmotic and mechanical stresses (Fu and Chen, 2011). Therefore, the preserving effects of the prebiotics for one bacterial strain in the tested conditions could not be extrapolated to other bacterial strains. According to the principal mechanisms of the protective properties of oligosaccharides, primarily through their impact on the glass transition process (Fritzen-Freire et al., 2012), enhanced cell survival is expected when their level in the drying media is increased. However, in the actual study, increased concentration of Synergy 1 from 1.5 to $5 \%$ $w / w$ did not provide increased cell survival or insignificantly improved the survival rate $(p>0.05)$ during the sprayand freeze-drying processes (Fig. 1). Similar behavior was observed when concentrations of FOS were increased from 1.5 to $5 \% w / w$ (Petreska Ivanovska et al., 2012b), suggesting that higher oligosaccharide level in the drying media probably contribute to increased osmotic stress which negatively affects the cell survival. However, when compared to the formulation without prebiotic, enhanced survival of co-encapsulated $L$. casei 01 with $1.5 \% \mathrm{w} / \mathrm{w}$ oligofructoseenriched inulin for approximately $1.2 \operatorname{logs}$ was achieved, confirming the protective role of the prebiotic used.

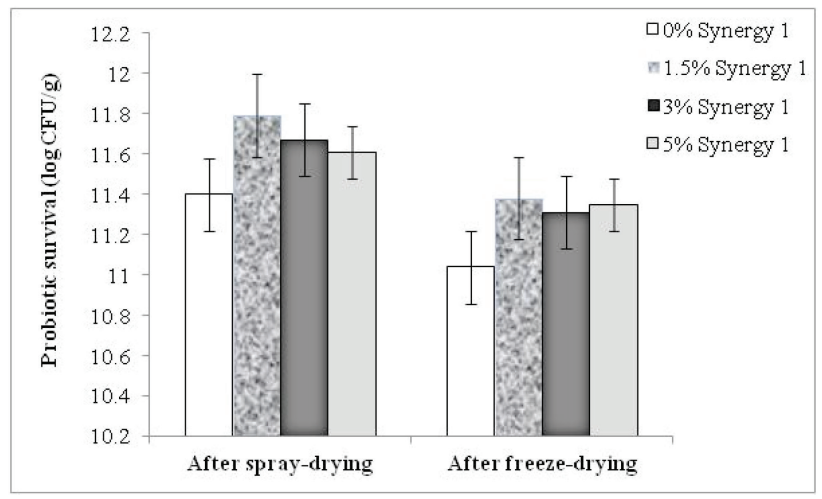

Fig. 1. Survival of Lactobacillus casei 01 during preparation of probiotic/synbiotic microparticles in a presence of different concentrations $(1.5,3$, and $5 \% w / w)$ of the prebiotic Synergy 1 (oligofructose-enriched inulin). Probiotic cell counts in the initial suspension were 12-12.2 $\log \mathrm{CFU} \mathrm{mL}^{-1}$.

\section{Survival of microencapsulated cells during storage}

Addition of the prebiotic oligofructose-enriched inulin during the microencapsulation increased the resistance of L. casei 01 cells to cold storage conditions (Fig. 2). Grad- 
ual decline of the probiotic viability in all examined samples during the whole storage period of 8 weeks was observed. At the 8 th week of storage, the number of probiotic cells encapsulated without prebiotic and with $1.5,3$, and $5 \% \mathrm{w} / \mathrm{w}$ oligofructose-enriched inulin was reduced by $3.55,2.35,2.51$, and $2.35 \operatorname{logs}$, respectively. Equal viability reduction was obtained with 1.5 and $5 \% \mathrm{w} / \mathrm{w}$ oligofructose-enriched inulin, indicating no need of increasing the prebiotic concentration above $1.5 \% w / w$. FOS added in the same formulation at the concentration of $3 \% w / w$ was slightly more effective compared to $1.5 \% \mathrm{w} / \mathrm{w}$, but the cell number reduction using 5\% $w / w$ FOS was even more higher than with $1.5 \% w / w$ (Petreska Ivanovska et al., 2012b). Presence of hydrolytic products of higher oligosaccharides or presence of excess glucose, fructose, and sucrose in the medium inhibited the usage of FOS by the probiotic Lactobacillus paracasei 1195 (Kaplan and Hutkins, 2003). This observation may explain the survival behavior of $L$. casei 01 when the level of oligofructose-enriched inulin is increased from 1.5 to $5 \% \mathrm{w} / \mathrm{w}$. With the comparative analysis of the protective effects of FOS and oligofructose-enriched inulin, each added in a concentration of $1.5 \% \mathrm{w} / \mathrm{w}$, lower viability loss of oligofructose-enriched inulin co-encapsulated L. casei 01 was obtained. Makras et al. (2005) observed fast growth of the probiotic $L$. paracasei subsp. paracasei 8700:2 in the presence of oligofructose and longchain inulin, but the same strain more efficiently degraded the oligosaccharides with short and medium chains such as oligofructose. This finding indicated that certain probiotic strains better utilized short-chain oligosaccharides such as oligofructose ( $\mathrm{DP}<10)$ compared to long-chain oligosaccharides (DP $>10)$. Since FOS from chicory used in our previous study has DP $>10$ (Petreska Ivanovska et al., 2012b), the presence of oligofructose in Synergy 1 was advantageous in terms of maintaining higher viable counts of L. casei 01 during storage of the microparticles. Unlikely to this, greatest stability of encapsulated $L$. rhamnosus GG was detected during cold storage of prebiotic edible films supplemented with inulin (Soukoulis et al., 2014). In the study of Fritzen-Freire et al. (2012), oligofructose-enriched inulin was found to better protect Bifidobacterium BB-12 during storage of the microcapsules produced by spray-drying, although oligofructose showed good protection as well. The divergence of the reported results is difficult to be explained since clear evidences on the specific protective action of the prebiotics such as FOS or inulin for each probiotic has not been provided yet (FritzenFreire et al., 2012).

Further, the lowest concentration of the prebiotic Synergy 1 provided significantly improved survival rate $(\mathrm{p}<$ 0.05 ) of co-encapsulated $L$. casei 01 , thus the concentration of $1.5 \% \mathrm{w} / \mathrm{w}$ seemed to be optimal to co-encapsulate L. casei 01 in chitosan-Ca-alginate microparticles using a spray-drying technique. This level is in accordance with the optimum dose of inulin type fructans ranged from 4-15 $\mathrm{g}$ on a daily basis (Yasmin et al., 2015) in order the prebi- otic to provide bifidogenicity, while avoiding GI adverse effects.

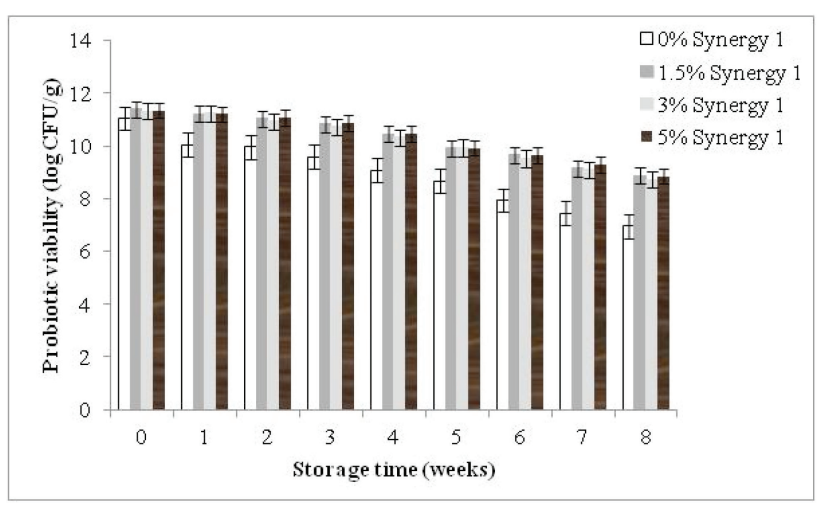

Fig. 2. Viability of Lactobacillus casei 01 encapsulated and co-encapsulated with the prebiotic Synergy 1 (oligofructose-enriched inulin) $(1.5,3$, and $5 \%$ $w / w)$ during 8 weeks of cold storage of the chitosan-Ca-alginate microparticles.

There are set of studies confirming improved stability of co-encapsulated probiotics with inulin, FOS or oligofructose-enriched inulin, but after being added to yoghurts or fruit juices (Capela et al., 2006; Krasaekoopt and Watcharapoka, 2014; Nazzaro et al., 2009; Petreska Ivanovska et al., 2014a). However, the cell survival during the storage of the food products may be additionally influenced by possible interactions of the food components with the bioactive compounds added or encapsulating materials.

\section{Adherence capacity of non-encapsulated L. casei 01 and synbiotic loaded microparticles}

Selection criteria of probiotics include bacterial ability to adhere to the intestinal mucosa, while proper selection of biopolymers applied to encapsulate the probiotics may exhibit improved muco-adhesion. In this study, biodegradable synbiotic chitosan-Ca-alginate microparticles were prepared using spray-drying method and subsequent freeze-drying in order to take advantage of the protective and muco-adhesive effects of polymers for improved intestinal delivery of the probiotic $L$. casei 01 . Since zeta potential of $L$. casei 01 cells measured in $\mathrm{pH} 6.8$ was found to be negative (-16.4 $\pm 0.7 \mathrm{mV}$ ) (Petreska Ivanovska et al., 2014a), indicating poor affinity to adhere to the negatively charged intestinal mucus, the adherence capacity of the encapsulated cells was investigated by in vitro adsorption test. The simplest model applied to investigate the adherence capacity of probiotic strains is by immobilization of commercially available pig mucin. The usage of PM, rich in MUC2, is advantageous due to the predominant expression of MUC2 in the large intestine, where colonization with probiotic bacteria preferably occurs, compared to in 
vitro models of different cell lines which are less abundant with MUC2 mucin, although better mimics the GI environment (Laparra and Sanz, 2009).

Low adsorption of PM on free cells surface (9.99 to $17.03 \%$ ) and excessive adsorption of PM on the surface of the $L$. casei 01 loaded microparticles $(51.87 \%$ to $68.81 \%)$ were observed in all buffers in the tested period of $24 \mathrm{~h}$ (Fig. 3 ). Adherence capacity values of $5.28 \pm 0.73,10.21 \pm 0.36$, $17.62 \pm 0.99$ and $31.07 \pm 1.02$ has been detected for $B$. bifidum, L. rhamnosus GG, B. lactis Bb12, and B. animalis, respectively, using in vitro model with crude mucin (type II) diluted in a phoshate-buffered solution ( $\mathrm{pH}$ 7.2) (Laparra and Sanz, 2009). With regard to these values, L. casei 01 possesses good adherence property. Muñoz-Provencio et al. (2009) have found high intra-species variability in adhesion properties using a collection of Lactobacillus casei strains from different origins, ranging from cheese isolates to commercial probiotics. The strains exhibited different binding levels to human colon fragments ex vivo which in the most cases had been found to correlate with the ability to in vitro binding of mucin. However, microencapsulation improved the adherence capacity, as significantly higher values $(\mathrm{p}<$ 0.05 ) for PM binding of $L$. casei 01 loaded microparticles compared to the free cells were obtained. Improvement of muco-adhesive characteristics of microparticles could be assigned primarily to the pseudoplastic behavior of increasing alginate concentrations (Kesavan et al., 2010) and pres- ence of charged or non-ionic functional groups in the structure of hydrophilic polymers able to form hydrogen bonds with mucosal surfaces (Khutoryanskiy, 2011). Further, chitosan as positively charged carrier may prolong the residence of encapsulated cells in the intestine by binding to the negatively charged glycoprotein from the mucus. A strong interaction between chitosan microspheres and mucin was detected in aqueous solution by turbidimetric measurements and biological studies confirmed that chitosan microspheres were retained in rat small intestine (He et al., 1998). Affinity of the prepared microparticles to attach to the intestinal mucus was confirmed with the positive surface charge of the chitosan-Ca-alginate microparticles (zeta potential, $+19.04 \pm 0.3 \mathrm{mV}$ ). Kim et al. (2008) reported no improvement in adhesion of microencapsulated L. acidophilus ATCC 43121 using alginate coating compared to nonencapsulated cells. The reason may be the specificity of the probiotic strain, cell sensitivity or changed muco-adhesive properties of alginate under conditions of atomization used for cell microencapsulation. No differences concerning adhesion ability to rat intestinal mucosa among free cells of $L$. casei ATCC 393 and immobilized ones using apple pieces have been found (Saxami et al., 2012). The rats were daily administered by fermented milk containing free or immobilized cells. However, it was reported that food matrix may affect surface properties and adhesion ability of lactic acid bacteria (Deepika and Charalampopoulos, 2010).

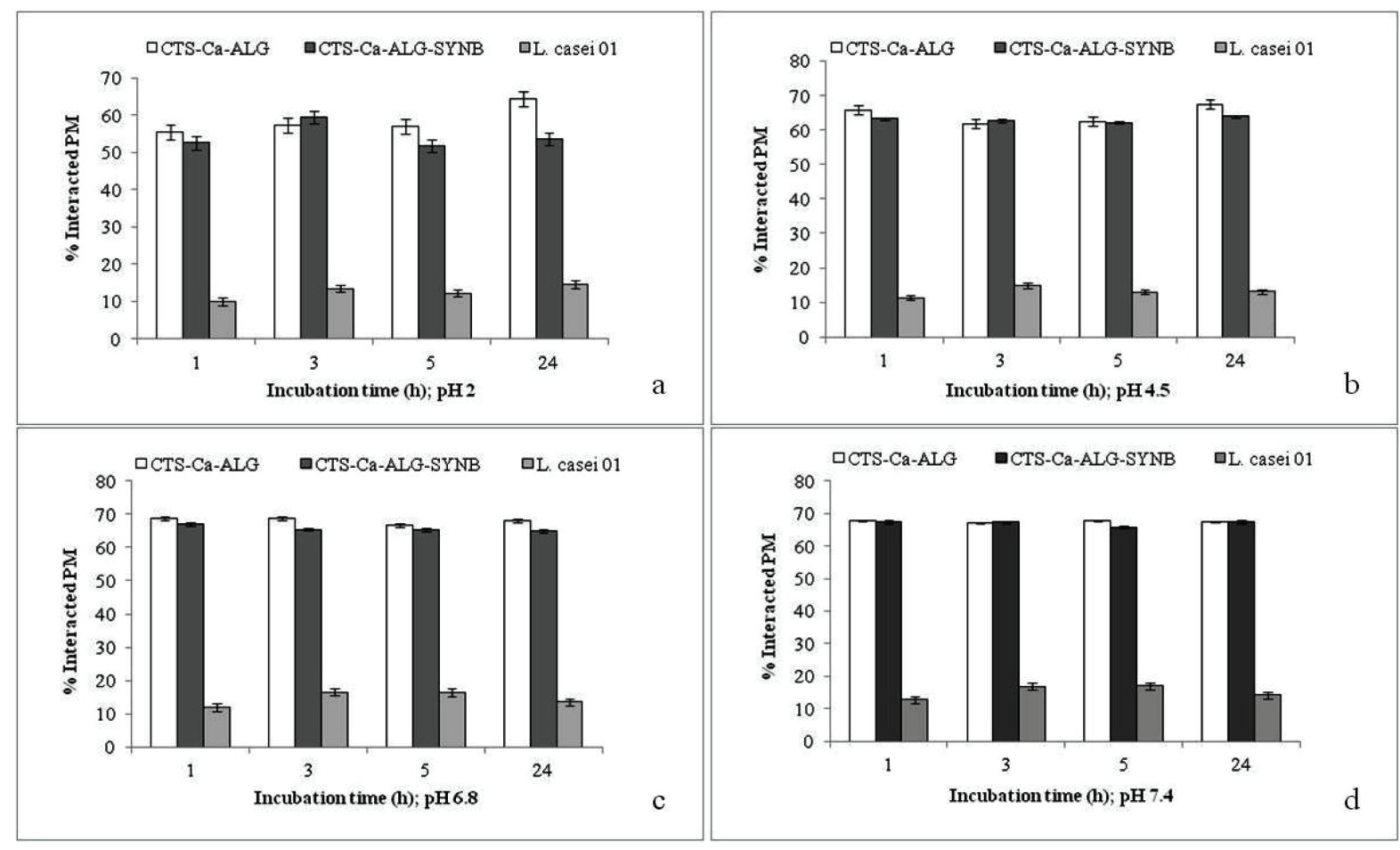

Fig. 3. Binding efficiency of pig mucin (PM) to free probiotic cells (L. casei 01), empty chitosan-Ca-alginate microparticles (CTS-Ca-ALG) and synbiotic chitosan-Ca-alginate microparticles (CTS-Ca-ALG-SYNB) in different buffer solutions: $\mathrm{pH} 2$ (a), pH 4.5 (b), $\mathrm{pH}$ 6.8, and $\mathrm{pH} 7.4$ during $24 \mathrm{~h}$ incubation period. 
No significant differences were found in adsorption of PM to empty and synbiotic microparticles under $\mathrm{pH} 2,4.5$, and 7.4 ( $\mathrm{p}>0.05)$, in our study. Only slight reduction in adsorption of PM to synbiotic microparticles compared to empty microparticles was observed in buffer solution with $\mathrm{pH}$ 6.8. These suggest that encapsulated cells did not negatively affect the muco-adhesion capacity of the polymer matrix. Insignificant changes of PM binding have been noticed during the whole incubation period of $1,3,5$, and 24 $h$ in each buffer $(p>0.05)$, thus the interactions of PM with free probiotic cells and/or microparticles were not dependant of the duration of incubation. After $24 \mathrm{~h}$ of incubation, the lowest adsorption of PM on the synbiotic microparticles was measured in $\mathrm{pH} 2(53.77 \pm 3.75 \%)$, while in $\mathrm{pHs} 4.5$, 6.8 , and 7.4 enhanced adsorption of $63.93 \pm 1,64.99 \pm 1.25$, and $67.45 \pm 0.63 \%$, respectively, was determined. The values for PM binding on the microparticles were increased with the increase of $\mathrm{pH}$, ranging from 2 to 7.4. These results are supported by the swelling of chitosan-alginate particles in weak acid and alkaline media accompanied with increased flexibility of the polymer chains which become capable to bind to mucus by hydrogen bonds, towards improved muco-adhesion. Increased PM binding in $\mathrm{pHs} 6.8$ and 7.4 indicated that synbiotic microparticles are able to retain in the lower GIT delivering viable probiotic cells, since adhesion is an important outcome for effective colonization by probiotics.

\section{Conclusion}

Oligofructose-enriched inulin added at the concentration of $1.5 \% \mathrm{w} / \mathrm{w}$ is an appropriate prebiotic to be used together with alginate and chitosan to microencapsulate $L$. casei 01 by spray-drying. The presence of the tested prebiotic was accompanied by enhancement of cell survival either during microencapsulation or cold storage of the encapsulated living cells, thus offering a potential as a functional ingredient to be applied in food products. In vitro enhanced PM binding to the L. casei 01 and oligofructose-enriched inulin loaded microparticles compared to free cells was detected. Correspondingly, synbiotic chitosan-Ca-alginate microparticles may provide favorable interaction with the negatively charged mucus glycoprotein, increase the muco-adhesion capacity of encapsulated probiotic and prolong the residence time in the lower intestine. Further research is required to study the adhesion to the large intestine in vivo and to prove the compatibility with a synbiotic effect.

\section{Acknowledgments}

This research was financially supported by the Ministry of Education and Science of the Republic of Macedonia (Project No. 13-3583/1). The authors would like to thank IMCD (UK) for the donation of sodium alginate (Protanal
10/60 LS, FMC BioPolymer, USA) and to Orafti Beneo Group and to IMCD (UK) for the donation of Orafti ${ }^{\circledR}$ Synergy 1 (L. Maréchal, Tienen, Belgium).

\section{References}

Almansa, C., Agrawal, A., Houghton, L.A., 2012. Intestinal microbiota, patophysiology and translation to probiotic use in patients with irritable bowel syndrome. Expert Rev. Gastroenterol. Hepatol. 6(3), 383-398.

Capela, P., Hay, T.K.C., Shah, N.P., 2006. Effect of cryoprotectants, prebiotics and microencapsulation on survival of probiotic organisms in yoghurt and freeze-dried yoghurt. Food Res. Int. 39, 203-211.

Charalampopoulos, D., Rastall, R.A., 2012. Prebiotics in food. Curr. Opin. Biotechnol. 23, 187-191.

Chen, S., Cao, Y., Ferguson, L.R., Shu, Q., Garg, S., 2013. Evaluation of mucoadhesive coatings of chitosan and thiolated chitosan for the colonic delivery of microencapsulated probiotic bacteria. J. Microencapsul. 30(2), 103-115.

Corcoran, B.M., Ross, R.P., Fitzgerald, G.F., Stanton, C., 2004. Comparative survival of probiotic lactobacilli spray-dried in the presence of prebiotic substances. J. Appl. Microbiol. 96, 1024-1039.

Deepika, G., Charalampopoulos, D., 2010. Surface and adhesion properties of lactobacilli. Adv. Appl. Microbiol. 70, 127-152.

Duncan, S.H., Flint, H.J., 2013. Probiotics and prebiotics and health in ageing populations. Maturitas 75(1), 44-50.

Fritzen-Freire, C.B., Prudêncio, E.S., Amboni, R.D.M.C., Pinto, S.S., Negrão-Murakami, A.N., Murakami, F.S., 2012. Microencapsulation of bifidobacteria by spray drying in the presence of prebiotics. Food Res. Int. 45, 306-312.

Fu, N., Chen, X.D., 2011. Towards a maximal cell survival in convective thermal drying processes. Food Res. Int. 44, 1127-1149.

Gentschew, L., Ferguson, L.R., 2012. Role of nutrition and microbiota in susceptability in inflammatory bowel disease. Mol. Nutr. Food Res. 56(4), 524-535.

Glavas Dodov, M., Calis, S., Crcarevska, M.S., Geskovski, N., Petrovska, V., Goracinova, K., 2009. Wheat germ agglutinin-conjugated chitosan-Ca-alginate microparticles for local colon delivery of 5-FU: development and in vitro characterization. Int. J. Pharm. 381, 166-175.

Gotteland, M., Andrews, M., Toledo, M., Munoz, L., Caceres, P., Anziani, A., Wittig, E., Speisky, H., Salazar, G., 2008. Modulation of Helicobacter pylori colonization with cranberry juice and Lactobacillus johnsonii La1 in children. Nutrition 24(5), 421-426.

He, P., Davis, S.S., Illum, L., 1998. In vitro evaluation of the mucoadhesive properties of chitosan microspheres. Int. J. Pharm. 166, 75-88.

ISAPP, 2008. $6^{\text {th }}$ Meeting of the International Scientific Association of Probiotics and Prebiotics. London, Ontario, Canada.

Kaplan, H., Hutkins, R.W., 2003. Metabolism of fructooligosaccharides by Lactobacillus paracasei 1195. Appl. Environ. Microbiol. 69, 2217-2222.

Kesavan, K., Nath, G., Pandit, J.K., 2010. Sodium alginate-based mucoadhesive system for gatifloxacin and its in vitro antibacterial activity. Sci. Pharm. 78(4), 941-957.

Khutoryanskiy, V.V., 2011. Advances in mucoadhesion and mucoadhesive polymers. Macromol. Biosci. 11(6), 748-764. 
Kim, S-J., Cho, S.Y., Kim, S.H., Song, O-J., Shin, I-S., Cha, D.S., Park, H.J., 2008. Effect of microencapsulation on viability and other characteristics in Lactobacillus acidophilus ATCC 43121. LWT-Food Sci. Technol. 41, 493-500.

Krasaekoopt, W., Watcharapoka, S., 2014. Effect of addition of inulin and galactooligosaccharide on the survival of microencapsulated probiotics in alginate beads coated with chitosan in simulated digestive system, yogurt and fruit juice. LWT-Food Sci. Technol. 57, 761-766.

Laparra, J.M., Sanz, Y., 2009. Comparison of in vitro models to study bacterial adhesion to the intestinal epithelium. Lett. Appl. Microbiol. 49, 695-701.

Macfarlane, S., Macfarlane, G.T., Cummings, J.H., 2006. Prebiotics in the gastrointestinal tract. Aliment. Pharmacol. Ther. 24, 701-714.

Makras, L., Van Acker, G., De Vuyst, L., 2005. Lactobacillus paracasei subsp. paracasei 8700:2 degrades inulin-types fructan exhibiting different degrees of polymerization. Appl. Environ. Microbiol. 71, 6531-6537.

Marteau P.R., de Vrese M., Cellier C.J., Schrezenmeir J., 2001. Protection from gastrointestinal diseases with the use of probiotics. Am. J. Clin. Nutr. 73, 430S-436S.

Meng, X.C., Stanton, S., Fitgerald, G.F., Daly, C., Ross, R.P., 2008. Anhydrobiotics: The challenge of drying probiotic cultures. Food Chem. 106, 1406-1416.

Mitropoulou, G., Nedovic, V., Goyal, A., Kourkoutas, Y., 2013. Immobilization technologies in probiotic food production. J. Nutr. Metab. 1-15, ID 716861.

Muñoz-Provencio, D., Liopis, M., Antolín, M., de Torres, I., Guarner, F., Pérez-Martínez, G., Monedero, V., 2009. Adhesion properties of Lactobacillus casei strains to resected intestinal fragments and components of the extracellular matrix. Arch. Microbiol. 191, 153-161.

Nazzaro, F., Fratianni, F., Coppola, R, Sada, A., Orlando, P., 2009. Fermentative ability of alginate-prebiotic encapsulated Lactobacillus acidophilus and survival under simulated gastrointestinal conditions. J. Funct. Foods 1, 319-323.

Nualkaekul, S., Deepika, G., Charalampopoulos, D., 2012. Survival of freeze dried Lactobacillus plantarum in instant fruit powders and reconstituted fruit juices. Food Res. Int. 48, 627-633.

Omar, J.M., Chan, Y., Jones, M.L., Prakash, S., Jones, P.J.H., 2013. Lactobacillus fermentum and Lactobacillus amylovorus as probiotics alter body adiposity and gut microflora in healthy persons. J. Funct. Foods 5, 116-123.

Orlando, A., Russo, F., 2012. Intestinal microbiota, probiotics and human gastrointestinal cancers. J. Gastrointest. Cancer 44(2), 121-131.
Peshev, D., Van den Ende, W., 2014. Fructans: prebiotics and immunomodulators. J. Funct. Foods 8, 348-357.

Petreska Ivanovska, T., Mladenovska, K., Kavrakovski, Z., Bogdanovska, L., Grozdanov, A., Popovski, E., PetrusevskaTozi L., 2012b. Effect of prebiotic content on functional and physicochemical properties on Lactobacillus casei loaded chitosan-Ca-alginate microparticles. Mac. Pharm. Bull. 58(1,2), 45-52.

Petreska Ivanovska, T., Petrushevska-Tozi, L., Grozdanov, A., Petkovska, R., Hadjieva, J., Popovski, E., Stafilov, T., Mladenovska, K., 2014a. From optimization of synbiotic microparticles prepared by spray-drying to development of new functional carrot juice. Chem. Ind. Chem. Eng. Quart. 20(4), 549-564.

Prakash, S., Tomaro-Duchesneau, C., Saha, S., Cantor, A., 2011. The gut microbiota and human health: an emphasis on the use of microencapsulated bacterial cells. J. Biomed. Biotechnol. 2-12.

Rößle, C., Brunton, N., Gormley, R.T., Ross, P.R., Butler, F., 2010. Development of potentially synbiotic fresh-cut apple slices. J. Funct. Foods 2, 245-254.

Sathyabama, S., Ranjith kumar, M., Bruntha devi, P., Vijayabharathi, R., Brindha devi, V., 2014. Co-encapsulation of probiotics with prebiotics on alginate matrix and its effect on viability in simulated gastric environment. LWT-Food Sci. Technol. 57, 419-425.

Saxami, G., Ypsilantis, P., Sidira, M., Simopoulos, C., Kourkoutas, Y., 2012. Distinct adhesion of probiotic strain Lactobacillus casei ATCC 393 to rat intestinal mucosa. Anaerobe 18, 417-420.

Soukoulis, C., Behboudi-Jobbehdar, S., Yonekura, L., 2014. Parmenter C., Stability of Lactobacillus rhamnosus GG in prebiotic edible films. Food Chem. 159, 302-308.

Tan, J., McKenzie, C., Potamitis, M., Thornburn, A.N., Mackay, C.R., Macia, L., 2014. The role of short-chain fatty acids in health and disease. Adv. Immunol. 121, 91-119.

Van Tassell, M.L., Miller, M.J., 2011. Lactobacillus adhesion to mucus. Nutrients 3, 613-636.

Watson, D., O'Connell Motherway, M., Schoterman, M.H.C., van Neerven, R.J.J., Nauta, A., van Sinderen, D., 2013. Selective carbohydrate utilization by lactobacilli and bifidobacteria. J. Appl. Microbiol. 114, 1132-1146.

Wickens, K., Black, P.N., Stanley, T.V., 2008. A differential effect of 2 probiotics in the prevention of eczema and atopy: a doble-blined, randomized, placebo-controlled trial. J. Allergy Clin. Immunol. 122, 788-794.

Yasmin, A., Butt, M.S., Afzaal, M., van Baak, M., Nadeem, M.T., Shahid, M.Z., 2015. Prebiotics, gut microbiota and metabolic risks: unveiling the relationships. J. Funct. Foods 17, 189-201. 


\title{
Резиме
}

\section{Влијание на инулин збогатен со олигофруктоза врз виталноста на микроинкапсулираниот Lactobacillus casei 01 и атхезивни својства на синбиотските микрочестички}

\author{
Тања Петреска Ивановска ${ }^{1}$, Зоран Живиќ ${ }^{1}$, Кристина Младеновска², Лидија Петрушевска-Този ${ }^{1 *}$

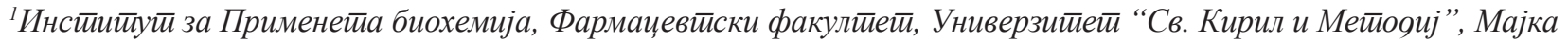 \\ Тереза 47, Скойје, Макеяонија

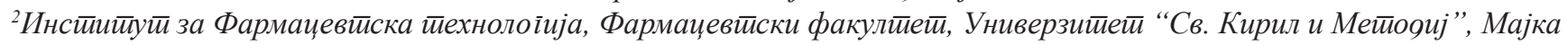 \\ Тереза 47, Скойје, Макеоонија
}

Клучни зборови: инулин збогатен со олигофруктоза, Lactobacillus casei, синбиотски микрочестички, муко-атхезија

Lactobacillus casei 01 беше ко-инкапсулиран со примена на различни концентрации на пребиотикот инулин збогатен со олигофруктоза за да се евалуира ефикасноста на пребиотикот во подобрување на пробиотската виталност во тек на микроинкапсулирање со сушење со распрснување и лиофилизирање. Притоа, беше следено и влијанието на пребиотикот врз стабилноста на инкапсулираните клетки при чување на $4{ }^{\circ} \mathrm{C}$ во тек на 8 недели. Атхезивноста на слободните клетки од L. casei 01 и микрочестичките со инкапсулирани клетки беше определена ин витиро со примена на муцин од желудник на прасе, заради проценка на улогата на микроинкапсулирањето во подобрување на атхезивните својства на L c casei 01 . Најголем степен на преживување на пробиотикот после подготовка со сушење со распрснување и лиофилизирање беше забележан кај микрочестичките подготвени со $3 \% \mathrm{M} / \mathrm{M}$ инулин збогатен со олигофруктоза, додека најголема стабилност на пробиотикот во тек на чување беше добиена кај микрочестичките подготвени со $1,5 \%$ м/м инулин збогатен со олигофруктоза. Ефикасноста во врзувањето на муцинот за микрочестичките беше значајно поголема во споредба со слободните пробиотски клетки во сите пуферски раствори што ги симулираат гастроинтестиналните услови во тек на инкубациониот период од $24 \mathrm{~h}$. Оттука, микроинкапсулирањето на $L$. casei 01 покрај подобрувањето на виталноста, може да обезбеди продолжен престој на пробиотските клетки во долниот интестинум како резултат на погодните муко-атхезивни својства на користените материјали за инкапсулирање. Добиените резултати покажуваат дека подготвените синбиотски цитозан-Са-алгинатни микрочестички претставуваат погоден систем за испорака на доволен број витални пробиотски клетки во долниот интестинум како целно ткиво за колонизација со пробиотици. 



\title{
Effect of Poloxamer on release of poorly water soluble drug Loratadine from solid dispersion: Kneading method
}

\author{
M. Mofizur Rahman ${ }^{1 *}$, Mohammad Moniruzzaman ${ }^{1}$, Sanjida Haque ${ }^{1}$, M.A.K. Azad ${ }^{1}$, \\ Farjana Islam Aovi ${ }^{2}$ and Nazneen Ahmeda Sultana ${ }^{1}$ \\ ${ }^{1}$ Department of Pharmacy, Bangladesh University, Dhaka, Bangladesh \\ ${ }^{2}$ Pharmacy Discipline, Khulna University, Khulna, Bangladesh
}

Received: January 2015; Accepted: May 2015

\begin{abstract}
The main objective of the current study was to enhance the solubility and dissolution of poorly water soluble drug Loratadine (LOR) through formulation of solid dispersion systems (SDs) using hydrophilic polymers. SDs were prepared by kneading method using different drug-to-polymer ratios (1:3 and 1:5) with poloxomer 188 (samples DS1, DS2) and poloxomer 407 (samples DS3, DS4) as hydrophilic polymers. In vitro drug release studies were performed on prepared SDs (DS1-DS4) and compared to pure drug (LOR only, sample DS0). Prepared SDs showed significant improvement in the release profile compared to LOR.
\end{abstract}

Key words: Loratadine, solid dispersions, poloxamer 188, poloxamer 407

\section{Introduction}

In solid dispersion systems (SDs), a drug may exist as an amorphous form in polymeric matrix, and this may result in improved solubility and dissolution rates compared with crystalline material. Several investigators proposed the mechanisms for the enhancement of the dissolution rate of SDs. For example, molecular dispersion of drug in polymeric matrix may lead to particle size reduction and surface area enhancement, which result in improved dissolution rates. Furthermore, no energy is required to break up the crystal lattice of a drug during dissolution process and improvement in drug solubility and wettability due to surrounding hydrophilic matrix (Yamashita et al., 2003).

Most of the recently introduced drugs, developed by combinatorial chemistry and high throughput screening techniques, suffer from poor solubility. SDs are useful for solving the solubility and bioavailability problem of such drugs (Leuner and Dressman, 2000). By definition SDs are formulations of finely crystalline or amorphous drug dispersed in an inert matrix (Chiou and Rigelman, 1971).

The methods used to prepare SDs include the melting method, the solvent method, and the solvent wetting method (Yh-Nam et al, 2000, Van den Mooter et al, 1998). USP, 1995 (United States Pharmacopoeia, 1995) state the use of kneading method for the preparation of SDs in purpose of dissolution enhancement.

Fast or immediate drug dissolution observed in SDs is most likely due to increased wettability, improved dispersibility of drug particles, existence of the drug in amorphous form with improved solubility and reduction or absence of aggregation and agglomeration of drug particles (Gohel and Patel, 2002).

In an SDs, drug and excipients (polymers) are mixed

\footnotetext{
* Tel: +8801911605139, E-mail: rmfi02@yahoo.com
} 
uniformly i.e., drug is mixed molecularly as crystalline or amorphous system. The polymers used in this system are divided into fully synthetic polymers and natural product-based polymers. Polyvinylpyrolidone (PVP), polyethyleneglycols (PEG), polymethacrylates and so on, are synthetic polymers which can be used for enhacement of solubility and dissolution of poorly water soluble drugs by SDs technique (Lima et al., 2011), whereas natural polymers are in particular composed of cellulose derivatives for instance hydroxypropylmethylcellulose (HPMC), ethylcellulose or hydroxypropylcellulose and cyclodextrins as well (Patel et al., 2012 and Ushesh, 2011). Amorphous SDs can be classified according to the molecular interaction of drug and polymers in solid solutions, solid suspensions or a mixture of both. In amorphous solid solutions, drug and polymers are totally miscible and soluble, originating from a homogeneous molecular interaction between them. Namely, in these systems, the drug and polymer interaction energy is extremely high, resulting in a really true solution (Costantino, 2002).

Loratadine (LOR), second-generation histamine H1 receptor antagonist is used in the treatment of allergic rhinitis and urticaria. Unlike most classical antihistamines (histamine $\mathrm{H} 1$ antagonists) it lacks central nervous system depressing effects such as drowsiness. Similar to other H1blockers, LOR competes with free histamine for binding at H1-receptors in the gastrointestinal tract, uterus, large blood vessels, and bronchial muscle. LOR also has a weak affinity for acetylcholine and alpha-adrenergic receptors. The poorly water-soluble drugs often show an erratic dissolution profile in gastrointestinal fluids, which consequently results in variable oral bioavailability. To improve the dissolution and bioavailability of poorly soluble drugs, researchers have employed various techniques, such as micronization, solubilization, salt formation, complexation with polymers, and change in physical form, use of prodrug and drug derivatization, alteration in $\mathrm{pH}$, addition of surfactants (BASF Technical Literature, 1998).

Poloxamers are nonionic polyoxyethylene-polyoxypropylene copolymers used primarily as emulsifiers, solubilizing agents, wetting agents and have been reported for enhancing the solubility and bioavailability of sparingly soluble drugs in SDs (Chen et al., 2004; Passerini et al., 2002 and Yu et al., 2007). For example, SDs were prepared with poloxamer by melting method for rofecoxib (Newa et al., 2008) and ibuprofen (Newa et al., 2008). Reduced crystalline structure and improved wettability (Shah et al., 2007; Chokshi et al., 2007) were mentioned as the mechanism by which poloxamer can enhance dissolution from SDs.

The objective of the present study was to improve the solubility and dissolution of LOR by SDs preparation using different ratios and types of water soluble polymers. In this study, SDs were formulated by kneading method using poloxamer 188 and poloxamer 407 at ratios of 1:3 and 1:5 of each. The formulations were characterized by in vitro dissolution study in order to compare the effects of polymers on LOR dissolution enhancement.

\section{Materials and Methods}

\section{Materials}

Loratadine (pure drug) was a gift sample from Beximco Pharmaceuticals Ltd., Dhaka, Bangladesh. Poloxamer 407 (Lutrol F-127) and poloxamer 188 (Lutrol F-68) were gifted by BASF, Germany. All other used reagents were with analytical grade.

\section{Preparation of solid dispersions}

SDs were prepared by kneading method. Exact amounts of drug (LOR) and excipients (poloxamers) (Table 1) were placed in the glass mortars separately and kneaded with pestle like a paste with addition of small amount of methanol and ethanol mixture $(4: 5 \mathrm{v} / \mathrm{v})$. Drug paste was added to excipients paste and further pestle kneaded. The pastes were transferred in three Petri dishes and oven dried $\left(30{ }^{\circ} \mathrm{C}, 5 \mathrm{~h}\right)$ (Hot Air Sterilizer GR-246, Shanghai China (Mainland). The dried samples were powdered by pestle in mortar.

\section{Linear regression loratadine standard curve}

Linear regression standard curve of LOR was created by plotting different drug concentration and corresponding absorbance values. Briefly, LOR standard solution (SS) $(20 \mathrm{mcg} / \mathrm{ml})$ was prepared by accurate weighting of 20 $\mathrm{mg}$ of LOR and its dissolution in $1000 \mathrm{ml}$ of $0.1 \mathrm{M} \mathrm{HCl}$. Working SSs $(2-20 \mu \mathrm{g} / \mathrm{ml})$ were prepared by serial dilution of SS with $0.1 \mathrm{M} \mathrm{HCl}$ in $10 \mathrm{ml}$ volumetric flask. Samples were analyzed by UV spectrophotometer (UV-mini-1240, SHIMADZU CORP., Kyoto, Japan)) at $280 \mathrm{~nm}$.

\section{Quantitative assay}

LOR quantitative assay was carried out for prepared SDs. $10 \mathrm{mg}$ equivalent of each SDs which contains $10 \mathrm{mg}$ LOR only were transferred in a $10 \mathrm{ml}$ volumetric flask. $10 \mathrm{ml}$ of metanol/water mixture $(1: 1 \mathrm{v} / \mathrm{v})$ was added, and sonicated (Power Sonic, Korea) until clear solution was obtained. The solution was filtered and diluted with distilled water (1:50). Similary, LOR solution $(1 \mathrm{mg} / \mathrm{ml})$ in metahnol/water mixture $(1: 1 \mathrm{v} / \mathrm{v})$ was prepared. LOR solution was filtered and diluted with distilled water (1:50 $\mathrm{v} / \mathrm{v}$ ) and hence LOR reference solution was obtained.

Absorbance values were determined using UVspectrophotometer (UV-mini-1240, SHIMADZU CORP., Kyoto, Japan), at $280 \mathrm{~nm}$. Solutions were also diluted if necessary. Using the absorbance values, the amount of LOR entrapped in SDs was calculated from LOR linear regression standard curve. 
In vitro release study of Loratadine from solid dispersions

In vitro dissolution study was performed in a paddle type Dissolution Apparatus (USP Type II Dissolution Apparatus, VEEGO, INDIA). Having in mind that LOR is poorly water soluble (about 0.004-0.006 mg/mL), in order to obtain sink conditions, $10 \mathrm{mg}$ equivalent of each prepared SDs (Samples DS1-DS4), was used for dissolution purpose. Dissolution of sample DS0 (pure drug, LOR only) was also performed. Distilled water (Qureshi, 2009) was used as dissolution media. Conditions for dissolution test were as follows: $900 \mathrm{ml}$ of distilled water, $37^{\circ} \mathrm{C}$ and a paddle speed of $100 \mathrm{rpm}$ (locally made, non-reactive, hollow sinker was used for maintaining sink condition). The dissolution was carried out for 50 minutes and $5 \mathrm{ml}$ sample was withdrawn at predetermined intervals of $5,10,15,20,30,40$, and 50 minutes. Each and every time $5 \mathrm{ml}$ dissolution sample was compensated by fresh $5 \mathrm{ml}$ distilled water. Dissolution samples were withdrawn with the help of disposable syringe filter and were kept in a test tube. The dissolution samples were then analyzed spectrophotometrically (UV-mini-1240, SHIMADZU CORP., Kyoto, Japan) at $280 \mathrm{~nm}$ and absorbance was noted. The dissolution study for each batch was performed in triplicate.

\section{Release Kinetics}

Zero-order, first-order, and Higuchi equation were applied to study the mechanism of drug release from the SDs. Having in mind that swelling of the matrix (upon hydration) and gradual erosion of the matrix might influence drug release, the dissolution data were also fitted according to the well-known exponential equation (Korsmeyer equation), Eq. (1), which is often used to describe the drug release behavior from polymeric systems.

$$
\log \left(\frac{M t}{M f}\right)=\log k+n \log t
$$

where, $M t$ is the amount of drug release at time $t$; $M f$ is the amount of drug release after infinite time; $k$ is a release rate constant incorporating structural and geometric characteristics of the tablet; and $n$ is the diffusional exponent indicative of the mechanism of drug release. A value of $\mathrm{n}=0.45$ indicates Fickian (case I) release; $>0.45$ but $<0.89$ for non-Fickian (anomalous) release; and $>0.89$ indicates super case II type of release. Case II generally refers to the erosion of the polymeric chain and anomalous transport (non-Fickian) refers to a combination of both diffusion and erosion controlled-drug release (Sato et al, 1997). Mean dissolution time (MDT) was calculated from dissolution data using the equation 2 (Mockel and Lippold, 1993).
$M D T=\left(\frac{n}{n+1}\right) \cdot K^{-\frac{1}{n}}$

\section{Comparison of Dissolution Data by Model Independent Methods}

Data obtained form in vitro drug release studies were tested with the model independent technique: dissolution efficiency $(\% \mathrm{DE}) . \% \mathrm{DE}$ was employed to compare the drug release from prepared SDs. Dissolution efficiency is the area under the dissolution curve within a time range $(t 1$ - $t 2$ ) expressed as a percentage of the dissolution curve at maximum dissolution, over the same time frame (Anderson, 1998). This was calculated from the equation 3 :

$\% D E=\frac{\int_{t_{1}}^{t_{2}} y \cdot d t}{Y_{100} \cdot\left(t_{2}-t_{1}\right)} \cdot 100$

where, $y$ is the percentage dissolved at time $t$.

\section{Results and discussion}

The effects of water soluble polymers (poloxamer 188 and poloxamer 407) on the formulations of LOR SDs were compared. The potencies of LOR in prepared SDs were analyzed by UV spectrophotometer and the results were within $99-100 \%$ in all cases which indicates uniform mixing of the dispersions.

\section{Dissolution studies}

The in vitro dissolution testing was performed for 50 minutes to ascertain the effect of formulations on immediate drug release enhancement. The effect of polymers on drug release from solid dispersion was evaluated by comparing the drug dissolution of LOR SDs (samples DS1-DS4) and pure drug (LOR only) (sample DS0). From Fig. 1, it can be clearly seen that LOR dissolution is much higher in prepared SDs compared to DS0. Namely, percent of dissolved LOR from DS0 for 50 min was 9.4, while from prepared SDs was $62.32 \%$ and $65.4 \%$ for DS1 and DS2 (poloxamer 188 based SDs) and $72.98 \%$ and $74.69 \%$ for DS3 and DS4 (poloxamer 407 based SDs), respectively. Highest percent of drug was released from DS4 and lowest drug release was found in DS1. Also, it can be noted that increase in polymer quantity (comparison of DS1vs DS2, and DS3 vs DS4) resulted with slight increase in percentage of dissolved drug. Improved drug dissolution in prepared SDs are most likely due to improved wettablity, formation of drug amorphous forms and probable decrease of particle 
Table 1. Composition of prepared formulations and data related to in vitro drug release study

\begin{tabular}{|c|c|c|c|c|c|c|}
\hline & & DS0 (mg) & DS1 (mg) & DS2 (mg) & DS3 (mg) & DS4 (mg) \\
\hline \multicolumn{2}{|l|}{ Loratadine } & 10 & 10 & 10 & 10 & 10 \\
\hline \multicolumn{2}{|c|}{ Poloxamer 188} & / & 30 & 50 & I & I \\
\hline \multicolumn{2}{|c|}{ Poloxamer 407} & l & I & l & 30 & 50 \\
\hline \multicolumn{2}{|c|}{$\mathrm{T}_{25 \%}$} & 21026.639 & 0.128 & 0.043 & 0.023 & 0.029 \\
\hline \multicolumn{2}{|l|}{$\mathrm{T}_{50 \%}$} & 43172.37 & 197.012 & 7.396 & 3.335 & 3.351 \\
\hline \multicolumn{2}{|l|}{$\mathrm{T}_{80 \%}$} & 1327.287 & 2432.44 & 242.948 & 96.897 & 83.795 \\
\hline \multicolumn{2}{|l|}{ MDT (min) } & 16556398 & 139.57 & 151.25 & 58.73 & 49.22 \\
\hline \multicolumn{2}{|l|}{$\% \mathrm{DE}$} & 7.64 & 50.61 & 52.83 & 59.49 & 60.26 \\
\hline \multirow[t]{2}{*}{ Zero order } & $\mathrm{R}^{2}$ & 0.693 & 0.63 & 0.613 & 0.614 & 0.985 \\
\hline & $\mathrm{K}_{0} \% \mathrm{~h}^{-1}$ & 0.153 & 1.009 & 1.03 & 1.163 & 0.395 \\
\hline \multirow[t]{2}{*}{ First order } & $\mathrm{R}^{2}$ & 0.648 & 0.723 & 0.716 & 0.744 & 0.768 \\
\hline & $\mathrm{K}_{1} \% \mathrm{~h}^{-1}$ & 0 & -0.007 & -0.007 & -0.009 & -0.01 \\
\hline \multirow[t]{2}{*}{ Higuchi } & $\mathrm{R}^{2}$ & 0.881 & 0.873 & 0.861 & 0.864 & 0.871 \\
\hline & $\mathrm{K}_{\mathrm{h}} \% \mathrm{~h}^{-0.5}$ & 1.31 & 8.66 & 8.92 & 10.06 & 10.27 \\
\hline \multirow[t]{2}{*}{ Korsmeyer } & $\mathrm{R}^{2}$ & 0.949 & 0.8858 & 0.965 & 0.989 & 0.973 \\
\hline & $\mathrm{n}$ & 0.16 & 0.154 & 0.135 & 0.14 & 0.146 \\
\hline
\end{tabular}

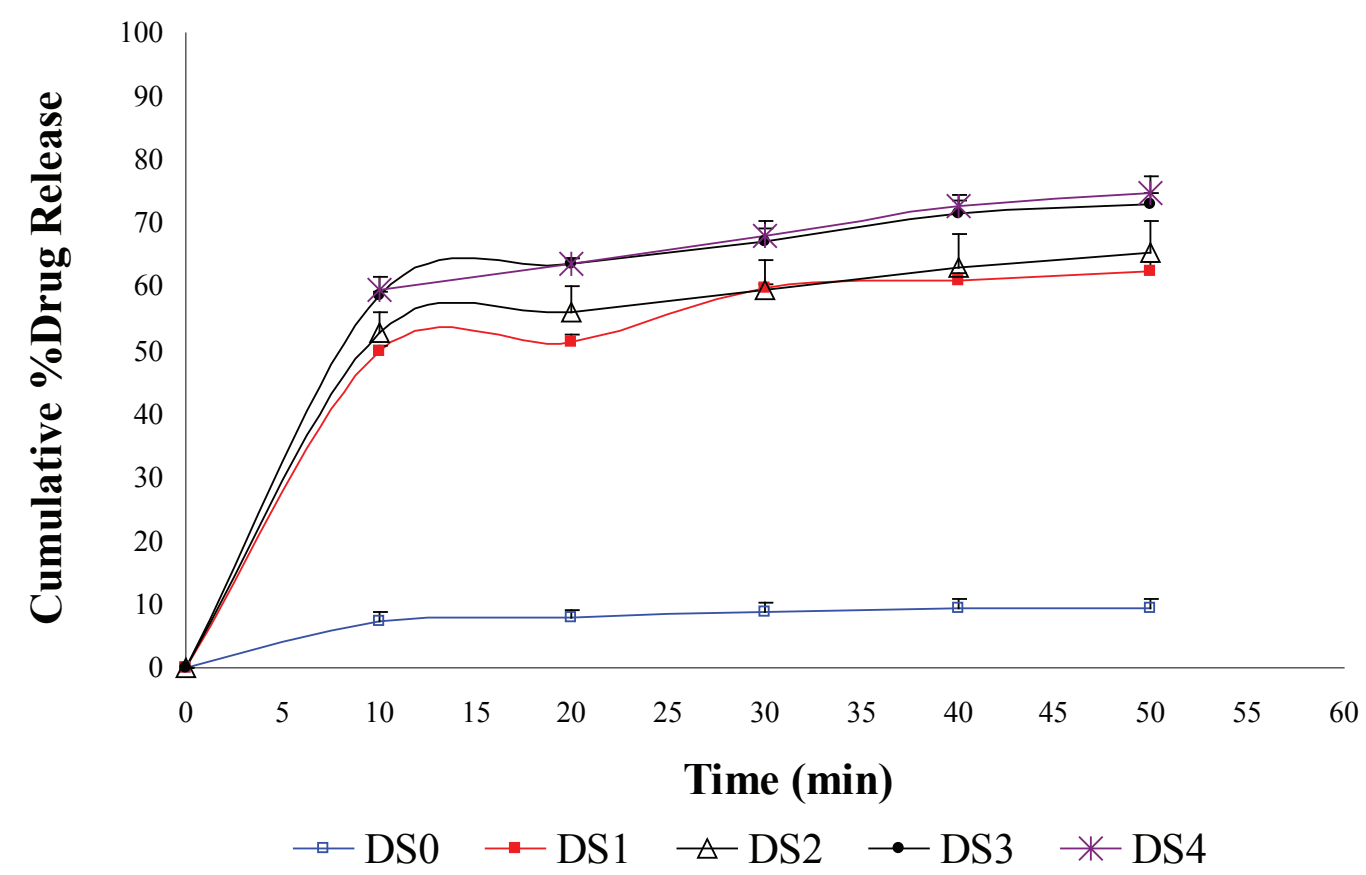

Fig. 1. In vitro release profile of loratidine from pure drug, DS0, and prepared solid dispersions (samples DS1-DS4) (n=3). 
size (Leuner and Dressman, 2000).

It was reported that molecular dispersion is one of the important roles of drug release from the polymer-drug system. The present work shows that the dissolution rate of LOR from SDs with poloxomers was improved compared to the pure drug. Further, SDs performed better than the corresponding physical mixtures (data not presented). Various studies have shown that freely water soluble polymers inhibit crystallization of drugs in SDs resulting in amorphous form of the drug in the SDs (Van den Mooter et al, 1998, Nalluri et al, 2003). Crystallization inhibition most likely is attributed to two effects: interactions, such as hydrogen bonding between the drug and the polymer and the entrapment of the drug molecules in the polymer matrix during solvent evaporation or a combination of both. The present study confirmed the advantage of improved aqueous solubility of LOR in its SDs form.

\section{Drug Release Kinetics}

Drug release from SDs was analyzed by Zero order model, First order, Korsmeyer model and Higuchi square root equation. Correlation coefficient $\left(R^{2}\right)$, drug release constant $(K)$ and diffusion exponent $n$ (where appropriate) for SDs and DS0 (LOR only) are presented in Table 1. It can be seen that samples DS0 and DS1-DS3 SDs followed Korsmeyer model, while DS4 showed best fit to zero order model.

\section{Model Independent Analysis of Dissolution Data}

The $\% \mathrm{DE}$ indicates the overall performance of the polymer in drug release. \%DE (Table 1) of all prepared SDs along with pure drug(LOR only) were calculated using Eq. $3(n=6)$. \%DE of sample DS0 was very low ( 8 $\%$, while the results indicate that SDs based on poloxamer 407 (samples DS3, DS4) had higher \%DE compared to SDs based on poloxamer 188 (samples DS1, DS2) i.e. app. $60 \%$ and $52 \%$, respectively.

It can be noted that $\% \mathrm{DE}$ slightly increased with increase of polymer quantity in poloxamer 188 (DS1, DS2) and poloxamer 407 (DS3, DS4) based SDs. Sample DS0 (LOR only) showed the highest MDT value which indicates the very poor release of drug, whereas in SDs, the lower MDT values were observed hence signifying the faster release of drug from prepared SDs. MDT values for DS1 and DS2 (poloxamer 188 based SDs) were much higher compared to DS3 and DS4 (poloxamer 407 based SDs).

\section{Conclusion}

Preparation of solid dispersions by kneading method is proven to be a useful technique to improve the solubility of poorly soluble drugs like loratadine. Solid dispersions of loratidin prepared with hydrophilic polymers (poloxamer 188 and 407) using the kneading method were characterized by improved loratidin dissolution. Solid dispersions based on poloxomer 407 showed improved dissolution compared to the poloxomer 188 based solid dispersion, and both had much better dissolution compared to pure drug. Experimental data suggested that the type of polymer and drug-polymer ratio are the critical factors for the development of solid dispersions.

\section{Acknowledgement}

The authors are thankful to Beximco Pharmaceuticals Ltd., Dhaka, Bangladesh for their generous donation of Loratadine. The authors are also thankful to Bangladesh University for their supports and co-operations.

\section{References}

Anderson, N.H., Bauer, M., Boussac, N., Khan-Malek, R., Munden, P. and Sardaro, M. 1998. An evaluation of fit factors and dissolution efficiency for the comparison of invitro dissolution profiles. J. Pharm. Biomed. Anal. 17 (4-5), 811-822.

BASF Technical Literature, Kollidone-Polyvinylpyrrolidone for pharmaceutical industry, BASF Aktiengesellschaft, Fine Chemicals, D-67056, Ludwigshafen; March 1998 (4th edition).

Chiou, W.L, Rigelman, S., 1971. Pharmaceutical application of solid dispersion system. J. Pharm. Sci. 60 (9), 1281-1302.

Chen, Y., Zhang, G.G.Z., Neilly, J., Marsh, K., Mawhinney, D., Sanzgiri, Y.D., 2004. Enhancing the bioavailability of ABT963 using solid dispersion containing pluronic F-68. Int. J. Pharm. 286 (1-2), 69-80.

Chokshi, R.J., Zia, H., Sandhu, H.K., Shah, N.H., Malick, W.A., 2007. Improving the dissolution rate of poorly water soluble drug by solid dispersion and solid solution:Pros and Cons. Drug Delivery 14 (1), 33-45.

Costantino, HR., Firouzabadian, L., Wu, C., Carrasquillo, K.G., Griebenow, K., Zale, S.E., Tracy, M.A., 2002. Protein spray freeze drying. 2. Effect of formulation variables on particle size and stability. J. Pharm. Sci. 91 (2), 388-395.

Gohel, M.C., Patel, L.D., 2002. Improvement of nimesulide dissolution from solid dispersions containing crosscarmellose sodium and Aerosil ${ }^{\circledR}$ 200. Acta Pharm. 52, 227-241.

Nalluri B.N., Chowdary, K.P.R, Murthy, K.VR.,; Hayman, A.R., Becket, G., 2003. Physicochemical characterization of nimesulide-cyclodextrin binary systems. AAPS PharmSciTech. 4 (1), 6-17.

Lima Ádley, A.N., Santos Polyana, B.S., Lyra Magaly, A.M., Santos Fabiana, L.A., Rolim-Neto, P.J., 2011. Solid dispersion systems for increase solubility: cases with hydrophilic polymers in poorly water soluble drugs. Rev. Bras. Farm. 92 (4),269-278.

Leuner, C., Dressman, J., 2000. Improving drug solubility for oral delivery using solid dispersions. Eur. J. Pharm. Biopharm., 50 (1), 47-60.

Mockel, J.E., Lippold, B.C., 1993. Zero order release from hydrocolloid matrices. Pharm. Res. 10 (7), 1066- 1070.

Newa, M., Bhandari, K.H., Oh, D.H., Kim, Y.R., Sung, J.H., Kim,

Макед. фарм. билт., 61 (1) 45 - 50 (2015) 
J.O., Woo, J.S., Choi, H.G., Yong, C.S., 2008. Enhanced dissolution of ibuprofen using solid dispersion with poloxamer 407. Arch. Pharm. Res. 31 (11), 1497-1507.

Passerini, N., Albertini, B., Gonzalez-Rodriguez, M.L., Cavallari, C., Rodriguez, L., 2002. Preparation and characterization of ibuprofen-poloxamer 188 granules obtained by melt granulation. Eur. J. Pharm. Sci. 15 (1), 71-78.

Patel, S.M., Patel, R.P., Prajapati, B.G., 2012. Solubility enhancement of benfotiamine, a lipid derivative of thiamine by solid dispersion technique. J. Pharm. Bioallied Sci. 4(Suppl 1), S104-S105.

Qureshi, S.A., 2009. Drug Testing: Selecting a dissolution medium for solid oral products. Am Pharm Rev. 12, 18-23.

Shah, T.J., Amin, A.F., Parikh, J.R., Parikh, R.H., 2007. Process optimization and characterization of poloxamer solid dispersions of a poorly water-soluble Drug. AAPS PharmSciTech. 8 (2) E18-E24.

Sato, H., Miyagawa, Y., Okabe, T., Miyajima, M., Sunada, H., 1997. Dissolution mechanism of diclofenac from wax matrix granules. J. Pharm. Sci. 86 (8), 929-934.

Talukder, M.M., Michoel, A., Rombaut, P., Kinget, R., 1996. Comaprative study on xanthun gum and hydroxypropyl methyl cellulose as matrices for controlled-release drug delivery. Int. J. Pharm. 129 (1-2), 231-241.

United States Pharmacopoeia, 23, NF 18. The USP Convention, Rockville 1995, pp. 1791-1799.

Ushesh, S.I., Vidhyadhar, H.B., Preeti, D.G., Sunil, P.P., 2011. Solubility enhancement of oral hypoglycemic agent by solid dispersion technique. IJABPT. 2 (2) 301-306.

Van den Mooter, G., Augustijns, P., Blaton, N., Kinget, R., 1998. Physicochemical characterization of solid dispersions of temazepam with polyethylene glycol 6000 and PVP K30. Int. J. Pharm.164 (1-2), 67-80.

Yamashita, K., Nakate, T., Okimoto, K., Ohike, A., Tokunaga, Y., Ibuki, R., Higaki, K., Kimura, T., 2003. Establishment of new preparation method for solid dispersion formulation of tacrolimus. Int. J. Pharm. 267 (1-2), 79-91.

Pan, R.N., Chen, J.H., Chen, R.R., 2000, Enhancement of dissolution and bioavailability of piroxicam in solid dispersions systems. Drug Dev. Ind. Pharm. 26 (9), 989-994.

Yu, H., Chun, M.K., Choi, H.K., 2007. Preparation and characterization of piroxicam/poloxamer solid dispersion prepared by melting method and solvent method. J. Kor. Pharm. Sci. 37 (1), 1-5.

\title{
Влијание на полоксамерите врз брзината на растварање на лоратадин од цврсти дисперзии подготвени со метод на месење
}

\author{
M. Mofizur Rahman ${ }^{1 *}$, Mohammad Moniruzzaman ${ }^{1}$, Sanjida Haque ${ }^{1}$, Md A K Azad ${ }^{1}$, \\ Farjana Islam Aovi ${ }^{2}$ and Nazneen Ahmeda Sultana ${ }^{1}$
}

${ }^{1}$ Department of Pharmacy, Bangladesh University, Dhaka, Bangladesh

${ }^{2}$ Pharmacy Discipline, Khulna University, Khulna, Bangladesh

Клучни зборови: Лоратадин, цврсти дисперзии, Poloxamer 188, Poloxamer 407

Цел на ова истражување беше формулирање на цврсти дисперзии со лоратадин (Lor) како активна супстанција, со т.н. метод на месење. Подготвените цврсти дисперзии би требало да ја подобрат растворливоста и брзината на растворање на Lor, како супстанција што покажува слаба растворливост во вода.

За таа цел, подготвени беа формулации на цврсти дисперзии со користење на Poloxomer 188 и Poloxomer 407 како хидрофилни полимери и различни соодноси на Lor-полимери (примероци DS1 и DS2, Lor/ Poloxomer 188 = 1:3 и 1:5; примероци DS3 и DS4, Lor/ Poloxomer $407=1: 3$ и 1:5).

Со цел да се согледа влијанието на хидрофилните полимери врз брзината на растворање на Lor од подготвените формулации, истите беа испитани со користење на соодветен in vitro дисолуциски метод.

Добиените резултати укажаа дека подготвените формулации на цврсти дисперзии значајно ја зголемуваат брзината на растворање на Lor во споредба со брзината на растворање на чиста активна супстанција. 


\title{
Patents and licensing in pharmaceutical industry
}

\author{
Katerina Ancevska Netkovska*, Jasmina Tonic Ribarska, Aleksandra Grozdanova, \\ Zoran Sterjev
}

Faculty of Pharmacy, University "Ss. Cyril and Methodius", Majka Tereza 47, 1000 Skopje, Republic of Macedonia

Received: March 2015; Accepted: May 2015

\begin{abstract}
Intellectual property rights (IPR) have been defined as ideas, inventions, and creative expressions based on which there is a public willingness to bestow the status of property. IPR provide certain exclusive rights to the inventors or creators of that property, in order to enable them to reap commercial benefits from their creative efforts or reputation. There are several types of intellectual property protection like patent, copyright, trademark, etc. Patent is recognition for an invention, which satisfies the criteria of global novelty, non-obviousness, and industrial application. IPR is prerequisite for better identification, planning, commercialization, rendering, and thereby protection of invention or creativity. Each industry should evolve its own IPR policies, management style, strategies, and so on depending on its area of specialty. Pharmaceutical industry currently has an evolving IPR strategy requiring a better focus and approach in the coming era. The protection of inventions with patents in the pharmaceutical industry have a specific role in the development of society and represent one of the drivers of economic development. The license agreements are considered as one of the most common types of transfer of industrial property rights. The right holders often transfer their rights to patents by concluding licensing agreement. While the patent license may give the license a right to use the technology many license agreements have provisions for the transfer of know-how in addition to the patent.
\end{abstract}

Keywords: license, transfer of rights, regulation, pharmaceutical industry

\section{Background}

Intellectual property is defined as a form of knowledge protected by specific proprietary rights, resembling ownership rights over material goods. Intellectual property state awards to individuals or organizations created intellectual creations: inventions, literary and artistic works, symbols, names, images and designs. The holder of intellectual property rights has exclusivity regarding the use of protected intellectual works within a specified period of time. After the expiration of that period, it becomes the subject of free use by all individuals and organizations in society, public domain. Intellectual property as a concept covers

\footnotetext{
* Tel.: +38923 126032; fax: +38923120220

e-mail address: kaan@ff.ukim.edu.mk
}

only a part of the knowledge accumulated in people, institutions and technologies within a society. With all the faster development of science and technology, especially in the area of biotechnology, medicine, information and communication technologies, knowledge becomes a greater source of competitive advantage for national economies. Trade in high-tech goods and intellectual services, where the protection of intellectual property rights is the greatest, is one of the sectors that developed fastest in the international trade. Intellectual property rights are based on the idea of balance between private and public interests. Timelimited, these rights protect private interests (by rewarding innovators and creators), but also the public interest (through promotion and dissemination of ideas, creative works and other works of the human mind). If the intellectual property system in a country is properly positioned 
and aligned with the specifics of its political, legal, cultural and overall social system, such a system could be used as a very successful tool for economic development (In the system of the United Nations Convention on no dichotomous classification "developed / developing countries." Grouping or labeling of certain countries or regions as "developed" or "developing" more details see: http://unstats. un.org/unsd/methods/m49/m49regin.htm\#ftnc. Macedonia is registered as one of the transition countries of Southeast Europe).

International technology transfer refers to the process by which a company from one country gets access to certain technology is initially developed in another country (Source: http:/www.wipo.int/pressroom/en/articles/2009/ article_0002.html.) and it starts successfully use it. Technology transfer can take place between partners who spontaneously enter into voluntary transactions, but can also take place through non-market transactions or etc. "Spillovers" (Fink and Maskus, 2005). The impact of the high level of protection of intellectual property rights on technology transfer is ambiguous in terms of theory and depends on circumstances that exist in a given country - recipient of technology. On the one hand, stronger intellectual property protection can limit the spread of technology, with the presence of patents that prevent unauthorized use of commercially valuable knowledge, as well as increased market power of the holders of intellectual property rights. It can also lead to potentially reduce the dissemination of knowledge, because of the relatively lower and higher production rates. On the other hand, relatively the stronger intellectual property rights can play a positive role in the dissemination of knowledge, given the detailed information about the technologies described in patent applications, made available to other potential inventors. In addition, the strong protection of intellectual property rights can stimulate technology transfer through increased trade in goods and services, foreign investment, technology licensing, and increased joint ventures. Despite the existence of theoretical ambiguity, the spread of technology from technologically developed countries to less developed are considered the main benefit of TRIPS. Benefits would be particularly important for developing countries that have no marked capacity for innovation. It is empirically proven that increased protection of intellectual property can encourage transfer of technology in various ways, though the final resultant effect is dependent on various factors including the ability of the country to support the legitimate imitations, and the level of technological development (World Bank 2008).

\section{Intellectual property rights}

The consequences of the high level of protection of intellectual property rights depend, among other things, the level of development of the country (expressed by gross domestic product per capita, or human capital). For most countries with relatively higher incomes, strengthening of intellectual property drives economic growth at least in part, due to increased innovation and increased dissemination of technology. Protection of intellectual property in these countries already meet or exceed the TRIPS standards, leaving the countries possibly strengthening the regime of their intellectual property rights (Fink and Maskus, 2005; World Bank, 2008).

Intellectual property should be seen as an instrument for achieving certain goals, which over time evolved and are specific to a period and a country. For example, in the US, the weak protection of copyright in the XIX century plan was aimed at encouraging the development of the domestic publishing industry. Similarly, in the history of the development of intellectual property systems in continental Europe, where the development of certain industries gradually grew and standards of protection of intellectual property (eg. in the pharmaceutical industry) or certain countries were forced to strengthen the system of industrial property by signing free trade agreements, eg. Spain and Portugal (Carlos Correa, Formulating effective pro-development national intellectual property policies, University of Buenos Aires ICTSD-UNCTAD Dialogue, Bellagio, 30 Oct.-2 Nov. 02.)

The formulation and implementation of appropriate national strategy in the field of intellectual property is a challenge for developing countries, particularly intellectual property should be put in function of economic development. There are several reasons why this task is challenging. The field of intellectual property is complex and includes multiple segments that have different roles (Patent, trademark, industrial design, copyright and related rights, etc.). Because of this, any generalization about the impact of the intellectual property system for the economic development of a country would have very little practical significance. Patents in the field of pharmaceutical products can lead to loss of static efficiency by disabling access to cheap medicines to the citizens of the country in development. On the other hand, brands can lead to increased levels of consumer protection through the designation of high quality products.

\section{Inovation and $R \& D$ in pharmaceutical sector}

The strict system of protection of intellectual property may have a different impact on different groups (eg, consumers and manufacturers) even within a single sector of the national economy. For example, a pharmaceutical company that invests significant resources in R \& D would be a potential advocate for the introduction of strict protection of industrial property rights in order to protect their inventions in which incorporated much like the material and the intellectual aspects. On the other hand, consumers would like to have access to a range of cheaper, generic drugs. Also, the introduction of strict system of protection of copyright and related rights in favor of musicians, art- 
ists, but this system can generate restrictive approach to the works of these artists by the poorest population.

The pharmaceutical sector is complex and highly regulated in most economies. Government price controls and purchasing, public and private insurance schemes, restrictions on marketing and promotion, and the involvement of "learned intermediaries" such as physicians and pharmacists powerfully influence demand for pharmaceuticals. On the supply side, stringent product safety review, regulatory oversight of manufacturing, and legal frameworks governing technology transfer between publicly-funded research institutions and commercial entities play an equally significant role in shaping competition. Importantly, since much of the research on pharmaceuticals has been focused on questions specific to the market institutions and regulatory framework of high-income economies such as the US and the EU, the extent to which this literature provides a firm foundation for evaluating the impact on policy changes in developing countries and countries with economies in transition is therefore unclear.

IPRs are generally understood to have two principal areas of impact in pharmaceuticals. First, there is the issue of pricing and access, where discussion focuses on the links between IPRs (particularly patent rights), exclusion of competitors and the availability and pricing of new medicines. Second, there is the issue of R\&D incentives - that is to say, the role of IPRs in providing incentives to discover, develop and market new drugs - and the effect of IPRs on R\&D expenditure and its allocation across diseases, countries and organizations. Obviously, these two issues are closely linked, and their interplay presents a series of very difficult economic issues and policy questions.

Even in a single-country context, the use of IPRs to reach an appropriate balance between "static" gains to consumers from low prices and competitive supply of drugs with "dynamic" gains from innovative new products presents serious challenges. On the one hand, industry feels acute financial pressure from rising R\&D costs and decreasing effective patent life. On the other, notwithstanding very substantial economic and health benefits associated with innovation in pharmaceuticals, even in relatively wealthy countries high prices for on-patent drugs tend to raise difficult political questions relating to equity and access for low-income or disadvantaged groups, and for setting priorities in allocating public health care budgets.

Looking cross-nationally, differences among countries in their approaches to these fundamental policy issues present additional challenges. The supply side of the industry operates globally. Industry R\&D is conducted largely by multinational companies who operate R\&D facilities in multiple countries, relying on and contributing to a transnational science base, and products are sourced and manufactured globally and are sold in essentially identical form in many different countries. Yet on the demand side, markets are essentially national, with significant hetero- geneity across countries in IPR regimes and health care insti- tutions.

The complexity of these issues demands careful empirical analysis. Yet, there are some very serious gaps in our knowledge, particularly as regards development of data that would support informative research into the impact of IPRs in this sector. Licensing as a channel of technology transfer can occur as a substitute for foreign direct investment. The level of protection of intellectual property rights may affect the selection of a company between licensing and foreign direct investment (Horstmann and Markusen, 1987). The high degree of protection of intellectual property contributes to favoring licensing by a firm technology provider because there is a legal framework that offers an opportunity for easy execution of licensing agreements. On the other hand, lack, ie low level of protection of intellectual property rights, and patents in particular, creates problems in the implementation of the licensing agreements (Markusen, 1995). In this case, the recipient of technology can quickly discern the technological procedure and imitated by creating a new local company that would emerge as a competitor to the provider of the technology. (Markusen and Maskus, 2001). From this perspective, the strong patent protection encourages increased conclusion of license agreements, since the patents act as inhibitors of potential risks in licensing of intellectual property.

Studies conducted on American multinationals have shown that the likelihood of licensing markets in developing countries is inversely proportional to the level of protection of intellectual property rights (Antras et al., 2006).

Therefore, this paper aims to give a brief overview of the segment of intellectual property in an area which is increasingly gaining in its importance. It is about the effects that provide patents on pharmaceutical companies and the importance of licensing in this business sector.

\section{Patents}

A patent is an exclusive right granted in the procedure by the Law (Law on industrial property „Official Gazzete of Republic of Macedonia” no. 21/2009, 24/2011, 12/2014, $41 / 2014,152 / 2015$ ), on inventions in all fields of technology which is new, it contains inventive contribution and can be applied in industry.

The patent is the right to intellectual property, which appears as the most widespread form, which has based inventor of the protected invention, and is an important factor for economic development and general progress (Cornish, 1993). The finding comes as the final result of the previous work, which is materialized the product of an individual or group of people, why legal protection enjoyed only one inventive work that gives certain results.

The patent as subjective right belongs to legal person, to a territory and for a certain time, and the holder of the patent rights have an exclusive right protected invention to use and exploit the material and moral values for the duration of patent protection. 
To protect as a patent need to build effective system that not only rewards the investment of time, money and effort it will provide and its adequate protection, which will stimulate innovation with new investments in research and development.

Patent may be for protection of a product, process or material. As necessary criteria that cumulatively fulfill the invention to be patentable: novelty, inventive step and applicability in industry (Polenak-Akimovska et al., 2004).

However, although the invention is patentable, it is always wise to apply for protection. A patent may be expensive, difficult to obtain, maintain and enforce, not to give the expected gain. Above all, it is necessary to do the analysis. The analysis should include the following elements: the existence of a market for the invention, the existence of an alternative and comparing whether and how useful for improving an existing product or developing a new product, having potencijlni buyers of the license, if the expected profit market will justify the costs of patenting, which aspects of the invention can be protected by one or more patents, will be easy to identify violation of the patent rights and finally, how the company will be able to apply patent.

Therefore, the patent serves as a powerful business tool to get a monopoly on a new product or process that is associated with the advancement of innovative companies in terms of dynamic business climate. The reasons for the findings pateniranje undeniable is their role to: competitive advantage in the market ${ }^{1}$, the higher the profit or return on investment, additional revenue from licensing or transfer of the patent, access to other technologies through cross-licensing, sale of new markets through licensing of patents reduced risk of damage to the patented invention, increased the possibility of obtaining grants, taking action against falsiifikuvanje positive view of the patent portfolio to business partners, investors, shareholders, customers and others ${ }^{2}$.

Statistically, companies that use intellectual property rights are more successful than those who do not use them ${ }^{3}$.

The surveyed companies said they use or plan to use one or more types of rights and the rank of those who are subject to registration as well as those that are not, including utility models $(16 \%)$, protected design (19\%), tech-

\footnotetext{
A patent gives the owner the exclusive right to prevent or stop others from commercially using the patented invention

2 We can treat it as a demonstration of the high level of expertise, specialization and technological capacity

3 Example: European companies in the sector of technology use intellectual property rights registered at least $10 \%$ a higher turnover, market share and new jobs. According to the International Data Corporation for the European Commission in 2008 in the sector of information and communication technology in eight EU Member States (Austria, Germany, Spain, France, Ireland, Italy, Poland and the UK), $89 \%$ of companies stated that PSI use one or more intellectual property rights, and $74 \%$ said that these rights important to them, while $34 \%$ rated them for,,very important,,.
}

nical measures protection $(27 \%)$, patents $(32 \%)$, brand $(40 \%)$, copyright $(46 \%)$ and trade secret $(72 \%)^{4}$.

In patent law distinguishes between the rights of the inventor and the right to the patent holder, since they do not have to belong to the same person.

If not also the inventor and patent holder enjoys the moral right to be appointed in the application and the documents concerning the patent. The holder of the patent, on the other hand have exclusive rights to the protected invention. According to its legal nature of this right is absolute character and the entry in the register has the effect erga omnes.

In the wider meaning the patent can be understood as a legal relationship that derive certain legal obligations as holder of the patent, and for all others. In narrower meaning, patent equals the subjective right arising from these legal relationships. According to the majority of legal theorists, the content of the subjective right arising from the patent as a legal relationship, the holder of a patent is a civil legal authority of title character (Polenak-Akimovska et al., 2004).

The content of the subjective right constitute rights are entitled exclusive rights (Law on industrial property „Official Gazzete of Republic of Macedonia”, no. 21/2009, 24/2011, 12/2014, 41/2014, 152/2015): the right to use, right to use the right to compensation and the right to prohibit third parties from unauthorized use ${ }^{5}$. Given its exclusive (absolute) legal nature, the holder of a patent confers the powers under certain authors may be characterized as positive and negative powers. The positive powers related to the ability to: 1 . use the protected invention in production, 2. to put into circulation objects made according to the protected invention, and 3 . dispose of the patent.

If the patent was obtained for the procedure, its effect extends to the products and materials obtained directly by that process (Law on industrial property „Official Gazzete of Republic of Macedonia”, no. 21/2009, 24/2011, 12/2014, 41/2014, 152/2015).

The negative aspect of the content of the patent covers the holder the right to prohibit use of the protected in-

\footnotetext{
4 International Data Corporation 2008: Intellectual property rights to use not only to protect their inventions and the market, but to attract investment, licensing and cross-licensing as well blocking competition. Also, at least 10\% more of the useful that these rights have reported growth for a period of 12 months and $61 \%$ higher turnover, $49 \%$ higher $42 \%$ market share and employment, as opposed to those who do not use them.

5 The content of the subjective right to the patent cost exclusive rights (legal property, positive powers) the patent holder to manufacture and circulates objects made according to the protected invention. This right is exclusive, monopolistic character, because only the patent holder and the persons who have his permission have the right to use, produce and put into circulation objects made according to the protected invention. Among these rights is no conditionality, because the exceptional right of putting items on the market is conditioned by the use in production.
} 
vention in production or sale of third parties', who use it do not have a license and refers to the manufacture, sale, export or import and storage products for such purposes (Law on industrial property „Official Gazzete of Republic of Macedonia", no. 21/2009, 24/2011, 12/2014, 41/2014, $152 / 2015)$.The patent holder has the right to prohibit third parties who do not have permission to use the protected invention in production or turnover. This right, which is a negative power is complementary to the positive powers by a right of personal use, with the right of possession to their qualification as exclusive rights.

In any case, it must be emphasized that the scope of the exclusive rights of the patent holder is determined by the text of the claims which are finally accepted in the patent granting procedure, where the description and drawings serve to interpret the claims (Law on industrial property „Official Gazzete of Republic of Macedonia”, no. 21/2009, 24/2011, 12/2014, 41/2014, 152/2015). There are situations when the right holder is limited, that there are exceptions to infringement of the patent, eg. Biotechnology (Law on industrial property „Official Gazzete of Republic of Macedonia", no. 21/2009, 24/2011, 12/2014, 41/2014, 152/2015).

It can be concluded that it is a monopoly right which contained more powers or rights holder of a patent. This character and the importance given to these rights, not only to meet the economic needs of the country but also to stimulate innovation and creativity (Polenak-Akimovska et al., 2004). Subjective rights arising from patent spatial, temporal and really limited. The territorial limitations apply that patent recognized by a state institution applies to the territory of that country. It should be noted that even in cases where the procedure for grant of patent is guided by an inter-state institution that has ovlastenje from several countries, after recognition of the patent applied teritoritorijalniot principle of importance, that subject to the provisions of national legislation. The territorial principle of protection is of particular importance in violation of the patent. Protection from harm is only possible in the country where the patent is valid or can not initiate dispute infringe the patent in a country where no registration. The timeframe of a patent is determined by the limited validity. The real limitation of the right is seen that the patent rights applies only to the object of the invention is protected by patent, and not to any other object.

Also, enumerates cases when the use of the invention protected by the patent does not constitute an infringement of a patent, or if the invention can be freely used (Law on industrial property ,Official Gazzete of Republic of Macedonia", no. 21/2009, 24/2011, 12/2014, 41/2014, $152 / 2015)$. The reasons that limit the effect of the patent in certain cases the use of social and social nature, in terms of meaning and purpose of patent protection. They relate to the use which is of such a scale and nature that causes extensive damage to the right holder, and use for scientific and research purposes. Here take into account the public interest. The exploitation of the protected invention in personal and non-commercial purposes (cumulative) is not a form of application which may endanger the use of the invention in the production and circulation of products according to the invention ${ }^{6}$. Activities undertaken research and development of the subject of the protected invention also allowed as free use of the patent. One of the primary purposes of patent protection is to encourage technological development, therefore it is logical to expect that patent protection should not be an obstacle for investigations that lead to further development in the field of the invention. This is especially important on how to use the case when the activities related to examinations and tests required for registration of medicines for human and veterinary medicine, medical and veterinary products or products for plant protection. Here it is cited in particular the case when it comes to inventions in these areas that require lengthy investigations and trials prior to commissioning, as is the case with pharmaceutical products (Polenak-Akimovska et al., 2004). Also, in case when referring to direct and individual preparation of medicines in pharmacies single doctors prescription. The provision refers to the procedure for preparation of the drug, if it is a protected procedure. The basis of this provision is in the general ethical and health interest, according to which a patent right should not be an obstacle to the preparation of the drug in individual cases. It is clear that the free use is possible only in case of individual preparation, not for production which will provide feedstock use, even in cases where production is realized in the pharmacy, which means that exempts production of medicines in galenic laboratories where they are intended for general application, not produced as individual products on the basis of a single prescription.

\section{The role of licencing patents in pharmaceutical indistry}

Licensing is considered one of the most important sources of international technology transfer to developing countries. It usually covers the purchase of rights to produce innovative goods or services, and / or rights to their distribution, and sale of basic technical information and know-how incorporated in the corresponding good, ie service. Licensing involves transfer of intellectual property which is affiliated with the innovative product, ie service, which appear as the subject of the license agreement (Yang and Maskus, 2003).

The relationship between licensing, technology dif-

\footnotetext{
This provision has the greatest practical significance for imported product for which there is a patent protection in the country of import. In this case, if the import is carried out for personal and non-commercial purposes, this action does not constitute a violation of the patent. Otherwise violate the law if imported products are intended for commercial purposes and for use by others.
} 
fusion and the level of protection of intellectual property is relatively complex and multifaceted than in other channels of technology transfer. One of the most important reasons according to Maskus (Maskus, 2003) lies in the diversity of the license agreements. License agreements can be concluded within the same group of companies within the joint venture, as well as between completely unrelated firms. These agreements may cover a wide range of areas, such as the subject of such contracts may be technical assistance, transfer of codified knowledge, transfer of knowledge and skills and transfer of intellectual property rights.

Today each country that seeks and highly prosperous economy, its development strategy through channel increasing degree of implementation mechanisms provided for the exercise of rights to protection of industrial property. The protection of inventions with patents in the pharmaceutical industry have a specific role in the development of society and represent one of the drivers of economic development. The costs that occur during the creation of new chemical supsatncii suspatnici as active in order for treatment is associated with building a reliable and efficient system in the research process. The length and duration of the research stages is difficult to predict because of many unpredictable moments. Therefore, it is common to take several years between baseline and registration of the first patent. The first patent application to register quite early, generally after the first detection of a successful operation, To ensure strict patent rights, and it would protect the third party. The purpose of patents is to create exceptions, but companies are not used to. The patent s right holder has the right to dispose of the patent. According to some scholars, the existence of positive powers is justified precisely by the right of disposal, especially the right of derogation the use of the patent by giving license.

The value of the patent or its licensing may differ greatly and may be difficult to determine the monetary value. Usually, it is compensation for the use of up to $5 \%$ of gross sales or $25 \%$ of net sales for those products include licensed invention. The license can also include advance payments in addition to the annual fee for use. There are companies that help the licensing of patents, and in return receive a share of the fee for licensing. Sometimes the amount of that portion can be one third of the benefits received by the license. If patents are available in technological areas that no one is interested, licensing may be a good alternative to doing nothing, ie to apply for a new patent ${ }^{7}$. Today, unless you pay fees to maintain the patent in force, the patent protection expires and technology over

For example, in Britain commenced granting licenses for drugs forced on the occasion of the introduction of public health protection. Ministry of Health of this country there was a need for large amounts of drugs, among them especially antibiotics. At that time antibiotics were modern drugs and patents for their production had big American corporations that put them on the market with higher prices. which it has rights over publicly available. Someone could be tempted to leave the patents developed technology that is commercialized or critical to the business. Perhaps with the help of external associates, lawyers or similar consulting firms can prepare a list of potential licensees, which will use the proper discretion of the pharmaceutical companies. If successful in licensing this patent unproductive capital can be turned into productive.

As a novelty in the Industrial Property Law in Macedonia which was introduced as a result of harmonization of national legislation with the Declaration which concerned the relationship of the TRIPS agreement, public health, pharmacy and complusory license taken within Doha Declaration, ratification of the European Patent Convention and issuance of the compulsory license. Before legislator refers to the release of complusory license so that if the patent holder does not use the invention protected by the patent or uses the extent insufficient to meet the needs of the domestic market, while refusing to enter into a license agreement or non-market sets conditions with a compulsory license the right to use the invention can be given to another person with responsibility for paying compensation to the holder of patent. These compulsory licenses may be issued to protect the public interest and in the health is particularly important for aspect of this work. In addition, we want to emphasize that the procedure for issuing a compulsory license shall be initiated by a lawsuit against the holder of the patent or supplementary protection certificate, which contains a requirement to issue a compulsory license. For the purposes of public health court, in accordance with Law to any person who has submitted a request to issue a compulsory license for a patent of supplementary protection or for the needs of production and sales of pharmaceutical products, if such products intended for export to importing countries problems in public health. In addition, the legislator defines country can be treated as an importing country or as a country that exported pharmaceutical products. The compulsory license can not be exclusive. The duration and scope of its issuance depend solely on the duration of the cause for which it was issued. The compulsory license may be transferred only together with the production capacity, ie the part in which the invention is used for validity. Also kolchinata products that can be produced on the basis of the compulsory license shall not exceed the amount needs to meet the importing country.

According to the Article 102, by Law on industrial property in Macedonia, any person that has filed an application in compliance with the provisions of this Law may be issued, by the court, a compulsory patent license i.e. a supplementary protection certificate for the needs of production and sale of pharmaceutical products, where such a product is intended to be exported in the importing countries with problems in public health. Also, when deciding upon issuing compulsory license, the court shall take into consideration the WTO General Council Decision of 30 August 2003 on the implementation of para- 
graph 6 of the Doha Declaration on the TRIPS Agreement and public health of 14 November 2001 (hereinafter referred to as: "Decision"). The pharmaceutical product referred to in paragraph (1) of this Article shall be any product in the pharmaceutical industry, including the medications for human use, which include any substance or mixture of substances designed for treatment or prevention of human diseases including any substance or mixture of substances which may be applied to people in terms of renewal, improvement, or adjustment to their physiological functions by causing pharmaceutical, immunological, or metabolic effects or by giving the medical diagnosis, including active components and accessories to diagnose outside the alive human body.

Because having a diametrically opposite social goals often comes to creating fiction between legal norms regulating unfair competition ( Law on Protection of Competition, Official Gazette no. 145 of 05.11.2010; Law against Unfair Competition, Official Gazette no. 80/99 of 17/12/1999) and intellectual property (Law on industrial property „Official Gazzete of Republic of Macedonia”, no. $21 / 2009,24 / 2011,12 / 2014,41 / 2014,152 / 2015)$. On the one hand, intellectual property rights creates exclusive and entry barriers to the market, in order to allow the company - holder of intellectual property the extra profit that would serve as an incentive to invest in the further creation of innovation. Ideally, such a balance provides consumers better products in the future, at the expense of somewhat higher current expenses. By contrast, legislation in the field of unfair competition, strives to enable consumers in a given moment to get the product at the lowest possible cost. In simple words, intellectual property law creates legal fictions in the form of monopoly and the right which regulates unfair competition contains express prohibitions on the formation of monopolies. The point of equilibrium between these two types of legislation will depend in part from the discount rate (cost of money) and balance present versus future; hence, the degree of balance between these two types of law will vary between relatively affluent and relatively poorer countries. For example, in the second half of last century until the seventies, in the legal system of the US balance was shifted strongly in favor of regulation of unfair competition, expelling it the intellectual property right (Barton, 2007).

Changes in the economic analysis also led to changes in legislation of developing countries which regulates the matter of unfair competition and intellectual property. Hence, the key issues emerged in the treatment of global oligopolies that could restrict access of developing countries to global competition and affect multinational acquisitions of local firms. From the perspective of developing countries that have a desire to acquire high technology, the most important international antitrust issues arising from the fact that much of the high technology to create so-called monopolies or oligopolies in a relatively small number of companies that may be willing to cross-license their technologies to one another, but are less willing to license their technology to potential new members of the oligopoly, and above all the companies coming from developing countries. As an example we can take the model of development of the sector of computer operating systems, the semiconductor sector and the sector of agricultural biotechnology (World Bank, 2008; Barton, 2007).

Concentration of industry in a monopoly or oligopoly may lead to unwanted cuts in investment in R \& D. Under such circumstances, some activities of leading firms could be antitrust violations. Antitrust argument is strongest if it leads to a company trying to gain market power beyond the scope of its acquired intellectual property, or if the company agrees to license its technology to the existing powerful competitors, but refuses to do so in a new competitor (for example, a company that comes from a developing country). When there are valid arguments for the protection of intellectual property, an appropriate solution to break the ensuing monopoly can be provided through the implementation of a compulsory license. Such circumstances are rare, and the applied standards are the subject of constant debate. However TRIPS allows such compulsory licenses within a reasonable range of anti-competitive situations (Fink and Maskus, 2005).

Another important antitrust issues for developing countries is the mode in which multinational companies will enable them to undertake local firms. Such acquisitions can be a normal step in the global movement of industries to large scale operations. In addition, downloads can bring new technology from abroad. This is the case particularly in the sectors of telecommunications and agricultural biotechnology. However, such acquisitions may affect the reduction of competition in developing countries. Balancing these two opposing effects requires a wise state antitrust body with considerable economic power (Fink and Maskus, 2005).

Another important antitrust issues for developing countries is the mode in which multinational companies will enable them to undertake local firms. Such acquisitions can be a normal step in the global movement of industries to large scale operations. In addition, downloads can bring new technology from abroad. This is the case particularly in the sectors of telecommunications and agricultural biotechnology. However, such acquisitions may affect the reduction of competition in developing countries. Balancing these two opposing effects requires a wise state antitrust body with considerable economic power (Fink and Maskus, 2005).

\section{Conclusion}

The protection of intellectual proerty right can be of a great importance for the development of a society, it can contribute to strengthening of economy and improve life standard. International community has established standards for protection of intellectual property rights through relevant international documents and thus gave guidelines 
on the improveent of thoir protection internationally. The states who are the leaders in innovation and creativity establish strong legal mechanisms which providethe protection of intellectual property rights. It is generally accepted that only legal use of intellectual property can bring innovation and progress to a society. There is a tendency in the international circles to support the flow of information and the freedom of expression through media especially now in the era of Internet. It is believed that it is necessary for all the sectors to cooperate with the state in order to find practical and efficient solutions for the protection of intellectual property rights. Types of intellectual property infigement are usually manifested through illegal production, smugglng and distribution of counterfeit products, including pharmaceuticals.

Considering the fact that the subject of protection are intellectual acts, we could conclude that patent legal rules achived high level of harmonization and unification. The tuning process followed by World Organization for Intellectual Property is synchronized with the same process on EU level. The global caracter of pharmaceutical company business asked for global rules in paten protecion of pharmaceutical products. The patent protection of pharmaceutical products is fundamentally to the pharmaceutical industry, which consists of two sectors: the innovative sector and generic sector. As far as the patents are concerned, recent academic works focus on several issues of impotrtance of patents: the actual impact of strong patents on innovation, commercialization, and economic growth, institutional factors, ranging from the structure of research organizations to seemingly tangential recommendation for future activities in using patents encompass data collection of R\&D output by the government agencies, research on patent policy implementation and policy changes (Hahn, 2003). The innovative sector is entirely dependet on patents and on a strong and effective patent protection system (20-year product patents protection can now be increased by up to more year through a Supplementary Protection Certificate). So, is thrue when the analyzing of intellectual property rights through the scope of economics in an outcome of concept of intellectual property is closely affiliated with innovation, technology and development. In the XXI century, intellectual property is no longer seen as an antonomous and separate area and has become a significant tool for policy making with socio-economic, technological and cultural repercussions (Mr. Kamil Idris, the Director General of WIPO 2007).

\section{References}

Antras, P., Garicano, L., Rossi-Hansberg, E., 2006. Offshoring in a Knowledge Economy. The Quarterly Journal of Economics, 121 (1), 31-77.

Barton, J.H., 2007. New trends in technology transfer: implications for national and international policy. ICTSD Programme on IPRs and Sustainable Development, Issue Paper No. 18. International Centre for Trade and Sustainable Development.

Correa, C. M., 2003. Can the TRIPS Agreement Foster Technology Transfer to Developing Countries? Duke University, manuscript.

Cornish, W.R., 1993. The International relations of intellectual property. Cambridge law journal.

Fink, C., Maskus, K.E., 2005. Intellectual Property and Development: Lessons from Recent Economic Research. World Bank Publications, Washington, DC.

Law on Protection of Competition, Official Gazette no. 145 of 05.11.2010

Law against Unfair Competition, Official Gazette no. 80/99 of $17 / 12 / 1999$

Law on industrial property „Official Gazzete of Republic of Macedonia“" no. 21/2009, 24/2011,12/2014,41/2014,152/2015

Polenak-Akimovska, M., Anastasovska Dabovik, J., Pepequgovski, V., Buckovski, V., Varga, Lj., Naumovski, G., 2004. Pravo na industriska sosptvenost, Skopje

Hahn, R.W., 2003. The Economics of patent Protection: Policy Implications from the Literature, AEI-Brookings Joint Center for Regulatory Studies, Washington, D.C.

Horstmann, I., Markusen, J. R., 1987. Licensing versus Direct Investment: A Model of Internalization by the Multinational Enterprise. Canadian Journal of Economics. 20(3), 464-481.

Markusen, J. R., 1995. The Boundaries of Multinational Enterprises and the Theory of International Trade. Journal of Economic Perspectives. 9 (2),169-189.

Markusen, J. R., Maskus, E. K., 2001. Multinational Firms: Reconciling Theory and Evidence, in: Topics in Empirical International Economics: A Festschrift in Honor of Robert E. Lipsey. National Bureau of Economic Research, Inc., pp 71-98.

Maskus, K.E., 2003. Encouraging international technology transfer. In UNCTAD/CTSD Capacity Building Project on International Property Rights and Sustainable Development, pp. 1-60.

World Bank , 2008. Global Economic Prospects: Technology Diffusion in the Developing World.

World Bank, 2011. World Development Indicators.

Yang, G., Maskus, K.E., 2003. Intellectual Property Rights, Licensing and Innovation. Policy Research Working Paper, The World Bank, No. 2973. 


\title{
Резиме
}

\section{Патенти и лиценцирање во фармацевтската индустрија}

\author{
Катерина Анчевска Нетковска*, Јасмина Тониќ Рибарска, Александра Грозданова, \\ Зоран Стерјев
}

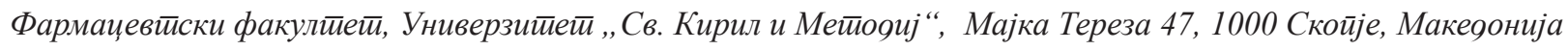

Клучни зборови: лиценца, пренос на правата, регулатива, фармацевтска индустрија

Правата на интелектуална сопственост (ПИС) се дефинирани како идеи, пронајдоци и креативни изрази кои обезбедуваат ексклузивни права на пронајдувачите или креаторите, со цел да им се овозможи користење на комерцијалните придобивки како резултат на нивниот креативен напор. Постојат неколку видови на заштита на интелектуалната сопственост, како патенти, авторски права, трговски марки и сл. Патентот е признание за пронајдок, кој ги исполнува критериумите на новост, инвентивност и индустриска применливост. ПИС е предуслов за подобра идентификација, планирање, комерцијализација, а со тоа и заштита на пронајдокот или креативност. Секоја индустрија треба да развива сопствени политики од интелектуална сопственост, управување со стил и стратегии во зависност од областа на специјалноста. Фармацевтската индустрија во моментов има стратегија на развојот на правата на интелектуална сопственост кои бараат подобар фокус и пристап во наредниот период. Заштитата на пронајдоци со патенти во фармацевтската индустрија има специфична улога во развојот на општеството и претставува еден од двигателите на економскиот развој. Лиценцните договори се сметаат за еден од најчестите типови на пренос на правата од индустриска сопственост. Носителите на правата често ги пренесуваат нивните права на патенти со склучување на договор за лиценцирање. 



\title{
Involvement of serum HSP 70 in Guillain-Barré Syndrome: An exploratory study and a review of current literature
}

\author{
Aida Loshaj-Shala ${ }^{1,2}$, Ana Poceva Panovska ${ }^{1}$, Katerina Brezovska ${ }^{1}$, \\ Giangiacomo Beretta $^{3 *}$, Ljubica Suturkova ${ }^{1}$, Slobodan Apostolski ${ }^{4}$ \\ ${ }^{1}$ Faculty of Pharmacy, University Ss. Cyril and Methodius, Skopje, Macedonia \\ ${ }^{2}$ Department of Pharmacy, Faculty of Medicine, University Hasan Pristina, Pristina, Kosovo \\ ${ }^{3}$ Department of Pharmaceutical Sciences DISFARM, University of Milan, Milan, Italy \\ ${ }^{4}$ Outpatient Neurological Clinic "Apostolski”, Belgrade, Serbia
}

Received: September 2014; Accepted: January 2015

\begin{abstract}
The evolutionary conserved family of heat shock proteins (HSP) is responsible for protecting cells against different types of stress. Although the levels of HSP can be readily measured in serum, the levels of HSP 70 in patients Guillain-Barre Syndrome (GBS) have not been studied before. To this aim we investigate whether patients with GBS $(n=21)$ had altered serum HSP 70 levels compared to healthy controls $(\mathrm{HC}, \mathrm{n}=9)$ and to patients affected by other immune disorders such as multifocal motor neuropathy (MMN, $\mathrm{n}=4)$ and chronic inflammatory demyelinating polyneuropathy (CIDP, $\mathrm{n}=6)$. The highest HSP 70 value $(15.78 \pm 1.72 \mathrm{ng} / \mathrm{mL})$ was found in one patient in the GBS group, although we have found that serum HSP70 levels were significantly higher in 2 out of the 21 GBS patients $(9.5 \%)$. Hence, it is of interest to underline that the patient with the highest HSP70 level, had also the best recovery rate. More extensive research is required in order to support the hypothesis that HSP 70 serum concentration may be a useful biomarker for the prediction of remission outcome for GBS patients.
\end{abstract}

Key words: Serum Heat Shock Protein HSP 70, Guillain-Barré Syndrome (GBS), ELISA.

\section{Introduction}

Guillain-Barré syndrome (GBS) is an acute inflammatory disorder where patients experience muscle weakness in the arms and legs (tetraplegia) as well as loss of deep tendon reflexes (areflexia). Surveillance studies from widely scattered geographical areas indicate that the annual incidence rate of GBS per 100,000 subjects ranges from 0.6 to 1.9. Higher incidence for developing GBS is in elderly, although it may affect persons of all ages.

There is a general misunderstanding about GBS, which is considered as a disease with good prognosis, while up to $20 \%$ of GBS patients remain severely disabled and ap-

\footnotetext{
* giangiacomo.beretta@unimi.it
}

proximately $5 \%$ die in the western countries (Hughes et al., 2007). GBS is currently the most common cause of acute flaccid paralysis worldwide since the near-elimination of poliomyelitis (Yuki, 2012).

GBS is usually preceded by an infection. A number of infectious agents seems to induce GBS, but their relation to the disease remains unclear. Among them, only Campylobacter jejuni is firmly established as a causative agent of GBS (Godschalk et al., 2004). Almost 25-40\% of GBS patients report history of gastroenteritis induced by $C$. jejuni infection 1-3 weeks prior to GBS onset (Nyati and Nyati, 2013). However, only 1 in 1000 patients, who are exposed to Campylobacter infection, develops GBS.

Infections with $C$. jejuni are associated with antibodies against human gangliosides GM1, GM1b, GD1a and 
GalNAc-GD1a (Willison and Yuki, 2002; Godschalk et al., 2004; Hughes and Cornblath, 2005).

The induction of these auto-antibodies has been associated with molecular mimicry between human ganglioside and bacterial epitopes present on the surface of the bacterial lipooligosaccharide, at least in those cases with a preceding $C$. jejuni infection and presenting antibodies to gangliosides (Koski, 1997; Nyati and Nyati, 2013; Yuki et al., 1997; Yuki, 1997),

Beside anti-ganglioside antibodies, it is believed that the etiological factors of several autoimmune diseases can be mediated by proteins belonging to the heat shock proteins (HSP) family (Yonekura et al., 2004).

HSP were discovered by Ritossa on 1962, who observed a puffing pattern in Drosophila chromosomes after exposure to heat. Since then, several investigations indicated the importance of HSP in clinical context (De Maio et al., 2012).

HSP are a family of highly conserved proteins present in all prokaryote and eukaryote cells under normal physiological conditions, and their overexpression is induced after different types of physiological stress (Arispe et al., 2002). These proteins play a crucial role in functioning as chaperones to prevent protein misfolding and aggregation (Craig et al., 1993).

Although their primary known action is intracellular, HSP are released in the extracellular environment and, recently, HSP 60 and HSP 70 have been described in the peripheral circulation in normal individuals and patients (Hantschel et al., 2000; Pockley et al., 1999). Recent evidence suggest that extracellular HSP 70 activates the immune system resulting in an inflammatory cascade (De Maio, 2011).

HSP 70 can be considered as the most conserved of the HSP families. It includes the cytosolic and nuclear constitutive Hsc 70 (HSP 73) and the stress-inducible HSP 70 (HSP 72) proteins, the endoplasmic reticulum (ER) Bip(Grp78), and the mitochondrial mt-HSP 70 (Grp 75) protein (Brocchieri et al., 2008). HSP 70 has been the subject of particularly extensive studies because it exhibits different functions in accordance with its location; intracellular HSP 70 exerts cytoprotective functions as a chaperone protein, whereas extracellular HSP 70 exerts immunomodulatory functions that trigger immunological responses (danger signals) as well as tolerance responses. (Mansilla and Montalban, 2012)

Hence, HSP appears to provide a further link between infection and autoimmunity. Similarity between bacterial and mammalian (macro)molecules may lead to human antigenic response either through recognition of conserved epitopes or via cross-reactivity termed molecular mimicry (Pockley et al., 1999).

Considering autoimmune conditions, previous studies assumed the involvement of HSP 70 in the pathogenesis of autoimmune disorders such as Grave's disease (Ratanachaiyavong et al., 1991), Behcet's disease (Birtas-Atesog- lu et al., 2008) and multiple sclerosis (MS) (Mansilla and Montalban, 2012). Elevated levels of serum HSP70 was found in atherosclerosis (Nakhjavani et al., 2010), Behcet Disease (Birtas-Atesoglu et al., 2008), systematic sclerosis (Ogawa et al., 2008), diabetes (Nakhjavani et al., 2010) and hepatic diseases (Gehrmann et al., 2014)

Concerning GBS, Yonekura et al. (2004) showed that GBS patients shared higher IgG antibody titers against several families of HSP (HSP 27, HSP 60, HSP 70) in their CSFs. However, there are contradictory findings concerning antibody titers to HSP family in sera. Yonekura et al. (2004) didn't find sera antibody titers to HSP family with significant differences between GBS patients and healthy control, while Helgeland et al. (2010) found significantly higher anti-HSP 70 antibody concentrations in sera from patients with GBS. Also Zhang et al. (2009) have found increased level of HSP 70 in experimental autoimmune neuritis, a Guillain-Barré syndrome (GBS) model.

To facilitate investigations on the possible clinical relevance of immunoreactive proteins in the development of GBS, recently our research group investigated the profiles and immunoreactivity of proteins from human peripheral nerve (HPN) tissue, the main pathological target of the disease, and from $C$. jejuni (O:19). The main candidate proteins identified in HPN were HSP in the Mw range between $60 \mathrm{KDa}$ and $70 \mathrm{KDa}$. In $C$. jejuni identified proteins were from the family of chaperone/co-chaperone proteins (DnaJ, DnaK and HtpG) (Loshaj-Shala et al., 2015).

Microbial DnaK ( $70 \mathrm{kDa})$ and HPN HSP 70 share high sequence homology, and HSP 70 autoantibodies have been shown in the human CSF (Yonekura et al., 2004)and sera of GBS patients (Helgeland et al., 2010), C. jejuni DnaK ( 70 kDa). For these reasons, DnaK /HSP can be suggested as carriers of possible antigen contributing to the induction of GBS (Shala et al., 2015).

Based on these findings, the aim of this study was to investigate whether patients with GBS had altered serum HSP 70 levels compared to healthy controls and to patients affected by other immune disorders such as multifocal motor neuropathy (MMN) and chronic inflammatory demyelinating polyneuropathy (CIDP). The results are discussed in the light of the previous relevant scientific literature.

\section{Materials and methods}

\section{Patient and control sera}

Before the specific treatments were given, and within a week from onset, electrophysiological findings and sera were obtained from $n=21$ patients with GBS consisting of $n=10$ AIDP, $n=3$ AMAN and $n=8$ with undefined form of GBS (11 men and 10 women; mean age 39 years). As a disease control, sera was also obtained from 4 patients with MMN (4 men; mean age 45 years), and 6 CIDP ( 5 men and 1 woman; mean age 51.5 years). Serum samples that were used in this study were from the diagnosed patients at the 
Neurological Clinic in the Clinical Center of Serbia. Sera donated from $\mathrm{n}=9$ healthy donors were used as normal control. All patients and healthy volunteers consented to participate in this study.

\section{Experimental setup}

Serum HSP 70 concentrations were measured using a HSP 70 ELISA kit (Sigma - Aldrich, USA) according to manufacturer instructions. All serum samples were tested at a 1:5 dilution with sample diluent buffer component provided with the kit. All experiments were performed in duplicate. Optical density (OD) was measured at $450 \mathrm{~nm}$ using a plate reader (Victor X4, Perkin Elmer, USA). The minimum detectable dose of human HSP 70 was $2 \mathrm{ng} / \mathrm{mL}$. The coefficients of variation were $10 \%$ for intra-assay determinations and $12 \%$ for inter-assay determinations. All OD readings were within the calibration curve limits.

\section{Statistical analysis}

All data were expressed as mean and standard deviation (SD). Before statistical analysis, normal dis-tribution and homogeneity of the variances were tested. Associations between the experimental parameters were investigated using one-way ANOVA, and differences between groups considered significant when $\mathrm{P}$-value was $<0.05$. Statistical analysis was performed using the R-commander GUI for R (v. 3.1.3) (Fox, 2005).

\section{Results and discussion}

\section{HSP 70 determination and comparison with previous re- sults}

The demographic characteristics of patients are summarized in Table 1.

In Fig. 1 are reported the HSP 70 levels detected by ELISA in patients experiencing the acute stage of GBS, MMN, CIDP and in HC subjects.

The results indicated no statistically significant difference in their mean \pm standard deviation values (ANOVA, $\mathrm{P}>0.05)$.
The highest HSP 70 value was found in one patient in the GBS group $(15.78 \pm 1.72 \mathrm{ng} / \mathrm{mL})$.

Table 2 shows a comparison of the HSP 70 levels found in our cohort of GBS patients compared to those reported for patients affected by other diseases, based on data reported by previous studies.

The mean levels reported in the present study were comparable with those reported for different liver conditions by (Gehrmann et al., 2014), while those reported by the other authors seemed to be lower depending on the reference study. Whether these differences may arise from the different patients demographic and genetic characteristics or from study-to-study differences in ELISA assay experimental set-up remains to be established.

Previously we investigated the profiles and immunoreactivity of peripheral nerve proteins and of $C$. jejuni, and reported that the main candidate proteins identified in the Mw range $60-70 \mathrm{KDa}$ where chaperone proteins of the HSP 70 family, and bacterial DnaK, GroEl and HtpG respectively (Loshaj-Shala et al., 2015).

In the present study we found that the serum levels of HSP 70 in sera from GBS patients where comparable with those found in $\mathrm{HC}$ and other autoimmune disorders.

However, 2 out of the 21 GBS patients (9.5\%) had higher HSP 70 level and it is of interest to underline that the patient with the highest HSP 70 level, had also the best recovery rate.

Extracellular HSP have been shown to act as potent immunostimulatory or immunosuppressive agents depending on the circumstances in which they interact with cells (Pockley et al., 2008).

De Maio, (1999) and Giffard et al. (2008) reported that the presence of HSP is important for the recovery from stress and protection from subsequent insults.

The importance of extracellular HSP has been emphasized by the detection of HSP 70 in the serum of patients suffering from an array of conditions and several autoimmune disorders. Among them, have been reported Grave's disease (Ratanachaiyavong et al., 1991), multiple sclerosis (MS) (Mansilla and Montalban, 2012), coronary artery diseases (Zhu et al., 2003), Behcet disease (BirtasAtesoglu et al., 2008), systematic sclerosis (Ogawa et al., 2008), diabetes (Nakhjavani et al., 2010) and hepatic dis-

Table 1. Demographic characteristics of patients. GBS: Guillain-Barré syndrome; CIDP: chronic inflammatory demyelinating polyneuropathy; MMN: multifocal motor neuropathy; HC: healthy controls

\begin{tabular}{cccc} 
Diagnosis & $\begin{array}{c}\text { No. of patients/sub- } \\
\text { jects }\end{array}$ & Age & Gender (M/F) \\
\hline GBS & 21 & $23-55$ & $11 / 10$ \\
CIDP & 6 & $35-68$ & $5 / 1$ \\
MMN & 4 & $32-58$ & $4 / 0$ \\
HC & 9 & $28-34$ & $5 / 4$ \\
\hline
\end{tabular}

Макед. фарм. билт., 61 (1) 61 - 67 (2015) 


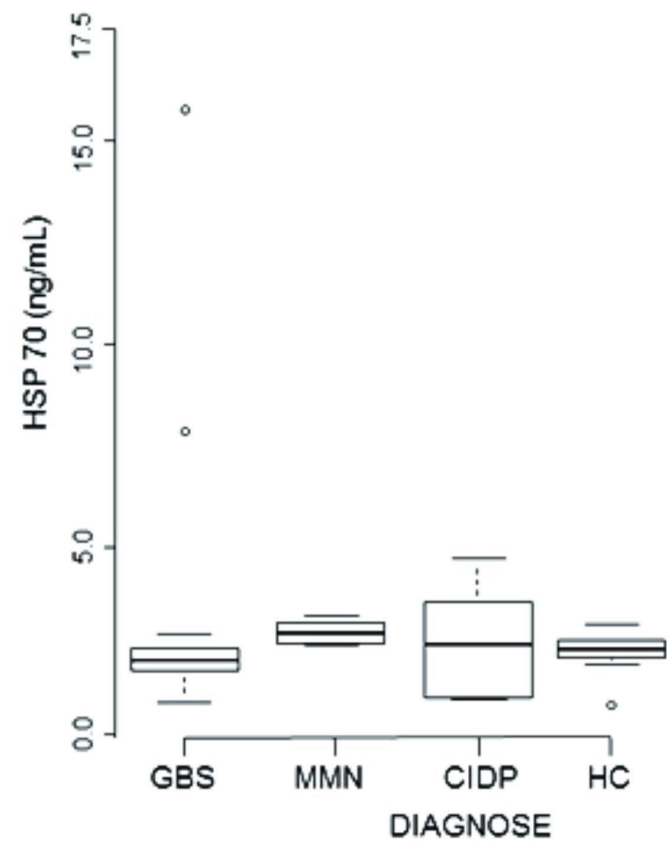

Fig. 1. HSP 70 serum levels detected in patients experiencing the acute phase of the Guillain-Barre syndrome patients (GBS, $\mathrm{n}=21$ ), multifocal motor neuropathy (MMN, $\mathrm{n}=4$ ), chronic inflammatory demyelinating polyneuropathy $(\mathrm{CIDP}, \mathrm{n}=6)$ and in healthy control subjects $(\mathrm{HC}, \mathrm{n}=9)$.

Table 2. HSP 70 serum levels in patients from different previously reported clinical studies N.R.: not reported
Disease
Disease $(\mathrm{ng} / \mathrm{mL})$
Control (ng/mL)
Reference

\begin{tabular}{|c|c|c|c|}
\hline Behçet Disease & $1.12 \pm 0.86($ mean $\pm \mathrm{SD})$ & $0.67 \pm 0.46($ mean $\pm \mathrm{SD})$ & Birtas-Atesoglu et al., 2008 \\
\hline Diabetes & $\begin{array}{l}0.70 \\
0.81-0.59 \text { (range) }\end{array}$ & $\begin{array}{l}0.23 \\
0.30-0.22 \text { (range) }\end{array}$ & Nakhjavani et al., 2010 \\
\hline $\begin{array}{l}\text { Hepatocellular carcinoma } \\
\text { (HCC) } \\
\text { Liver cirrhosis (LC) } \\
\mathrm{B} / \mathrm{C} \text { viral infection } \mathrm{CH}\end{array}$ & $\begin{array}{l}6.5-3.1 \text { (range) } \\
6.6-5.2 \\
3.9-2.4\end{array}$ & $2.7 \pm 0.9($ mean $\pm \mathrm{SD})$ & Gehrmann et al., 2014 \\
\hline $\begin{array}{l}\text { Coronary artery disease } \\
\text { (CAD) }\end{array}$ & $\begin{array}{l}0.5 \text { (median) } \\
27.1-0.2 \text { (range) all subjects } \\
0.34 \quad \text { (median) } \quad \mathrm{P}=0.0006 \\
(\mathrm{CAD} \text { vs. non } \mathrm{CAD})\end{array}$ & 0.72 (median, non CAD) & Zhu et al., 2003 \\
\hline Asthma & $\begin{array}{l}0.46 \text { (median) } \\
0.20-0.98 \text { (range) }\end{array}$ & $\begin{array}{l}0.14 \text { (median) } \\
0.11-0.37 \text { (range) }\end{array}$ & Hou et al., 2011 \\
\hline Chronic Fatigue Syndrome & $0.58 \pm 0.16$ & $1.64 \pm 0.18$ & Jammes et al., 2012 \\
\hline Vascular Calcification & $0.63(0.52-0.81)$ & N.R. & $\begin{array}{l}\text { Krepuska et al., 2011as well } \\
\text { as to markers of inflammation } \\
\text { (C-reactive protein }\end{array}$ \\
\hline GBS & $\begin{array}{l}3.101 \pm 3.27(\text { mean } \pm \mathrm{SD}) \\
2.208 \text { (median) } \\
1.18-15.78(\text { range })\end{array}$ & $\begin{array}{l}2.43 \pm 0.58(\text { mean } \pm S D) \\
2.5 \text { (median) } \\
1.12-3.1 \text { (range) }\end{array}$ & Current study \\
\hline
\end{tabular}

eases (Gehrmann et al., 2014). Krepuska et al. (2011) reported that serum level of soluble Hsp70 is associated with vascular calcification.
Zhang et al. (2009) reported increased levels of HSP 70 in an experimental model of autoimmune neuritis resembling GBS. 
HSP have been found also in the serum of apparently healthy individuals (Xiao et al., 2003).

The presence of HSP 70 in circulation has been correlated with improved survival of critically ill patients. Pittet et al. (2002) reported that HSP 72 can be detected in the serum of severely traumatized patients within 30 minutes after injury. Elevated initial serum levels of HSP 72 are associated with survival after severe trauma, but are not related to the incidence or severity of the post injury inflammatory response or organ dysfunction.

Ziegler et al., (2005) also investigated the role of HSP70 in survival of patients in critical stage. These authors observed that parenteral glutamine administration significantly increases serum HSP 70 and that the magnitude of HSP 70 enhancement was correlated with improved clinical outcomes in patients treated with glutamine.

Regarding the protective role of HSP 70, May et al. (2013) reported that HSP 70 release from supporting cells is necessary and sufficient to protect mechanosensory hair cell neurons from the toxic effects of aminoglycoside antibiotics, which is of broad importance, as there are currently no known ways to reduce the toxicity of this class of antibiotics.

The authors demonstrated that the release of HSP 70 from the glia-like supporting cells settled at the base of the hair cells leads to this protection, indicating two central findings: first, the neighboring glial cells release the HSP 70 that provides protection. Second, the extracellular HSP 70 appears sufficient to protect the neurons, without requiring significant uptake. These findings points to a critical role for signaling by HSP 70, rather than its established function as a direct molecular chaperone.

The work extends the broader understanding of the role of extracellular HSP 70 as a molecule for transmission of signals from one cell to another, likely through binding to cell surface receptors. The receptor for HSP70 in this setting is currently unknown (May et al., 2013).

Psychological stress and exercise that do not induce substantial cell death, lead to significant increases in extracellular HSP 70 (Giffard et al., 2013).

Furthermore, May et al. (2013) suggested the possibility that defective chaperone secretion or function could directly contribute to hear loss/balance disturbance if the hair cell is not protected. Similar consequences appears in other conditions in which defective chaperones contribute to pathogenesis (Macario and de Macario, 2005)

Tidwell et al. (2004) reported very promising results about the remedying properties of Hsc/HSP 70 in reducing the loss of neurons after exogenous administration in neonatal mouse. The authors examined the regulation of the constitutive and stress-induced 70-kD HSP (Hsc 70 and HSP 70, respectively) after sciatic nerve (SN) axotomy in the neonatal mouse. They found that endogenous levels of Hsc70 and HSP 70 did not increase significantly in lumbar motor neurons or dorsal root ganglion sensory neurons up to 24 hours after axotomy. However, after administra- tion of HSP 70 preparations to the SN stump after axotomy, the survival of both motor and sensory neurons was significantly improved. These results support the hypothesis that immediate application of exogenous Hsc 70 or HSP 70, or both, may be physiologically similar to induced synthesis of endogenous HSP 70 and can increase survival of damaged neurons.

Thus, Hsc70 and HSP 70 as new therapeutical agents in the prevention of immunologically mediated neurodegeneration need to be further studied.

\section{Conclusion}

In the present study, extracellular HSP 70 was monitored in the serum of patients with GBS and other neurological immune mediated diseases MMN, and CIDP.

The mean HSP 70 serum levels didn't show significant variations among these groups. The positive correlation with disease remission in two patients with GBS carrying the highest HSP 70 concentrations, although limited to a low number of patients, are supportive of a peripheral neuroprotective role of extracellular HSP 70, in good accordance to the results from several studies reported in the literature.

Our data encourage us to hypothesize that HSP 70 serum concentration may be a useful biomarker for the prediction of remission outcome for GBS patients. However, additional detailed studies involving a higher number of patients are necessary to confirm this hypothesis.

\section{Acknowledgments}

This work was in part supported by a grant from Santefarm (Pristina, Kosovo).

\section{Disclosure}

All the authors declare no disclosures.

\section{Author contributions}

A. L-S. and L. S. conceived the study design, participated in its design and in the management of sample collection and acquisition of data. A. L-S. and A. P. P. carried out the experiments, participated in the sample collection, acquisition of data, analysis and interpretation, and drafting of the manuscript. G. B. helped to analyze data and previous literature and to draft and revise the manuscript text, tables and figures. K. B. helped in sample management. S.A. did neurological assessment and diagnosis of patients and provided the samples. All authors read and approved the final submitted version of the manuscript. 


\section{References}

Arispe, N., Doh, M., De Maio, A., 2002. Lipid interaction differentiates the constitutive and stress-induced heat shock proteins Hsc70 and Hsp70. Cell Stress Chaperones 7, 330338.

Birtas-Atesoglu, E., Inanc, N., Yavuz, S., Ergun, T., D.H., 2008. Serum levels of free heat shock protein 70 and anti-HSP70 are elevated in Beh?et's disease. Clin. Exp. Rheumatol. 26, 96-98.

Brocchieri, L., Conway de Macario, E., Macario, A.J.L., 2008. hsp70 genes in the human genome: Conservation and differentiation patterns predict a wide array of overlapping and specialized functions. BMC Evol. Biol. 8, 19.

Craig, E., Gambill, B.D., Nelson, R.J., 1993. Heat shock proteins: molecular chaperones of protein biogenesis. Microbiol. Rev. 57, 402-414.

De Maio, A., 1999. Heat shock proteins: facts, thoughts, and dreams. Shock 11, 1-12.

De Maio, A., 2011. Extracellular heat shock proteins, cellular export vesicles, and the Stress Observation System: A form of communication during injury, infection, and cell damage: It is never known how far a controversial finding will go! Dedicated to Ferruccio Ritossa. Cell Stress Chaperones 16, 235-249.

De Maio, A., Gabriella Santoro, M., Tanguay, R.M., Hightower, L.E., 2012. Ferruccio Ritossa's scientific legacy 50 years after his discovery of the heat shock response: A new view of biology, a new society, and a new journal. Cell Stress Chaperones 17, 139-143.

Fox, J., 2005. The R Commander: A Basic-Statistics Graphical User Interface to R. J. Stat. Softw. 14, 1-42.

Gehrmann, M., Cervello, M., Montalto, G., Cappello, F., Gulino, A., Knape, C., Specht, H.M., Multhoff, G., 2014. Heat shock protein 70 serum levels differ significantly in patients with chronic hepatitis, liver cirrhosis, and hepatocellular carcinoma. Front. Immunol. 5, 307.

Giffard, R.G., Han, R.-Q., Emery, J.F., Duan, M., Pittet, J.F., 2008. Regulation of apoptotic and inflammatory cell signaling in cerebral ischemia: the complex roles of heat shock protein 70. Anesthesiology 109, 339-348.

Giffard, R.G., Macario, A.J.L., De Macario, E.C., 2013. The future of molecular chaperones and beyond. J. Clin. Invest. 123, 3206-3208.

Godschalk, P.C.R., Heikema, A.P., Gilbert, M., Komagamine, T., Wim Ang, C., Glerum, J., Brochu, D., Li, J., Yuki, N., Jacobs, B.C., Van Belkum, A., Endtz, H.P., 2004. The crucial role of Campylobacter jejuni genes in anti-ganglioside antibody induction in Guillain-Barré? syndrome. J. Clin. Invest. 114, 1659-1665.

Hantschel, M., Pfister, K., Jordan, a, Scholz, R., Andreesen, R., Schmitz, G., Schmetzer, H., Hiddemann, W., Multhoff, G., 2000. Hsp70 plasma membrane expression on primary tumor biopsy material and bone marrow of leukemic patients. Cell Stress Chaperones 5, 438-442.

Helgeland, G., Petzold, A., Hoff, J.M., Gilhus, N.E., Plant, G.T., Romi, F.R., 2010. Anti-Heat Shock Protein 70 antibody levels are increased in myasthenia gravis and GuillainBarré? syndrome. J. Neuroimmunol. 225, 180-183.

Hou, C., Changchun, H., Zhao, H., Haijin, Z., Li, W., Wenjun, L., Liang, Z., Zhenyu, L., Zhang, D., Dan, Z., Liu, L., Laiyu, L., Tong, W., Wancheng, T., Cai, S.-X., Shao-Xi, C., Zou,
F., Fei, Z., 2011. Increased heat shock protein 70 levels in induced sputum and plasma correlate with severity of asthma patients. Cell Stress Chaperones 16, 663-671.

Hughes, R.C., Cornblath, D.R., 2005. Guillain-Barré syndrome. Lancet 366, 1653-1666.

Hughes, R.C., Swan, A. V, Raphaël, J.-C., Annane, D., van Koningsveld, R., van Doorn, P., 2007. Immunotherapy for Guillain-Barré syndrome: a systematic review. Brain 130, 2245-2257.

Jammes, Y., Steinberg, J.G., Delliaux, S., 2012. Chronic fatigue syndrome: Acute infection and history of physical activity affect resting levels and response to exercise of plasma oxidant/antioxidant status and heat shock proteins. J. Intern. Med. 272, 74-84.

Koski, C.L., 1997. Mechanisms of Schwann cell damage in inflammatory neuropathy. J. Infect. Dis. 176, S169-S172.

Krepuska, M., Szeberin, Z., Sótonyi, P., Sarkadi, H., Fehérvári, M., Apor, A., Rimely, E., Prohászka, Z., Acsády, G., 2011. Serum level of soluble Hsp 70 is associated with vascular calcification. Cell Stress Chaperones 16, 257-265.

Loshaj-Shala, A., Regazzoni, L., Daci, A., Orioli, M., Brezovska, K., Panovska, A.P., Beretta, G., Suturkova, L., 2015. Guillain Barr? syndrome (GBS): new insights in the molecular mimicry between C. jejuni and human peripheral nerve (HPN) proteins. J. Neuroimmunol. 289, 168-176.

Macario, A., de Macario, E.C., 2005. Sick chaperones, cellular stress, and disease. N. Engl. J. Med. 353, 1489-1501.

Manouchehr Nakhjavani, Afsaneh Morteza, Leila Khajeali, Alireza Esteghamati, Omid Khalilzadeh, Firouzeh Asgarani, T.F.O., 2010. Increased serum HSP70 levels are associated with the duration of diabetes. Cell Stress Chaperones 15, 959-964.

Mansilla, M., Montalban, X., 2012. Heat Shock Protein 70: Roles in Multiple Sclerosis. Mol. Med. 18, 1018-1028.

May, L., Kramarenko, I.I., Brandon, C.S., Voelkel-Johnson, C., Roy, S., Truong, K., Francis, S.P., Monzack, E.L., Lee, F.S., Cunningham, L.L., 2013. Inner ear supporting cells protect hair cells by secreting HSP70. J. Clin. Invest. 123, 35773587.

Nakhjavani, M., Morteza, A., Khajeali, L., Esteghamati, A., Khalilzadeh, O., Asgarani, F., Outeiro, T.F., 2010. Increased serum HSP70 levels are associated with the duration of diabetes. Cell Stress Chaperones 15, 959-964.

Nyati, K.K., Nyati, R., 2013. Role of Campylobacter jejuni infection in the pathogenesis of Guillain-Barré syndrome: an update. Biomed Res. Int. 2013, 852195.

Ogawa, F., Shimizu, K., Hara, T., Muroi, E., Hasegawa, M., Takehara, K., Sato, S., 2008. Serum levels of heat shock protein 70, a biomarker of cellular stress, are elevated in patients with systemic sclerosis: association with fibrosis and vascular damage. Clin. Exp. Rheumatol. 26, 659-662.

Pittet, J.F., Lee, H., Morabito, D., Howard, M.B., Welch, W.W., Mackersie, R.C., 2002. Serum levels of Hsp 72 measured early after trauma correlate with survival. J Trauma. 2002 Apr;52(4)611-7; Discuss. 617. 52, 611-617.

Pockley, A.G., Muthana, M., Calderwood, S.K., 2008. The dual immunoregulatory roles of stress proteins. Trends Biochem Sci. 33, 71-79.

Pockley, G., Bulmer, J., Hanks, B.M., Wright, B.H., 1999. Identification of human heat shock protein 60 (Hsp60) and anti-Hsp60 antibodies in the peripheral circulation of normal individuals. Cell Stress Chaperones 4(1), 29-35.

Ratanachaiyavong, S., Demaine, A.G., Campbell, R.D., 
Mcgregor, A.M., 1991. Heat shock protein 70 (HSP70) and complement $\mathrm{C} 4$ genotypes in patients with hyperthyroid Graves' disease. Clin. Exp. Immunol. 70, 48-52.

Tidwell, J.L., Houenou, L.J., Tytell, M., 2004. Administration of Hsp70 in vivo inhibits motor and sensory neuron degeneration. Cell Stress Chaperones 9, 88-98.

Willison, H.J., Yuki, N., 2002. Peripheral neuropathies and antiglycolipid antibodies. Brain 125, 2591-2625.

Xiao, C., Wu, T., Ren, A., Pan, Q., Chen, S., Wu, F., Li, X., Wang, R., Hightower, L.E., Tanguay, R.M., 2003. Basal and inducible levels of Hsp70 in patients with acute heat illness induced during training. Cell Stress Chaperones 8, 86-92.

Yonekura, K., Yokota, S.I., Tanaka, S., Kubota, H., Fujii, N., Matsumoto, H., Chiba, S., 2004. Prevalence of anti-heat shock protein antibodies in cerebrospinal fluids of patients with Guillain-Barré syndrome. J. Neuroimmunol. 156, 204 209.

Yuki N, Taki T, Inagaki F, Kasama T, Takahashi M, Saito K, Handa S, M.T., 1997. A bacterium lipopolysaccharide that elicits Guillain-Barré syndrome has a GM1 ganglioside-like structure. J. Exp. Med. 178, 1771-1775.
Yuki, N., 2012. Guillain-Barré syndrome and anti-ganglioside antibodies: a clinician-scientist's journey. Proc. Jpn. Acad. Ser. B. Phys. Biol. Sci. 88, 299-326.

Yuki, N., 1997. Molecular mimicry between gangliosides and lipopolysaccharides of Campylobacter jejuni isolated from patients with Guillain-Barré syndrome and Miller Fisher syndrome. J. Infect. Dis. 176 Suppl, S150-S153.

Zhang, Z.Y., Zhang, Z., Schluesener, H.J., 2009. Toll-like receptor-2, CD14 and heat-shock protein 70 in inflammatory lesions of rat experimental autoimmune neuritis. Neuroscience 159, 136-142.

Zhu, J., Quyyumi, a. a., Wu, H., Csako, G., Rott, D., ZallesGanley, a., Ogunmakinwa, J., Halcox, J., Epstein, S.E., 2003. Increased Serum Levels of Heat Shock Protein 70 Are Associated With Low Risk of Coronary Artery Disease. Arterioscler. Thromb. Vasc. Biol., 23(6), 1055-1059.

Ziegler, T.R., Ogden, L.G., Singleton, K.D., Luo, M., FernandezEstivariz, C., Griffith, D.P., Galloway, J.R., Wischmeyer, P.E., 2005. Parenteral glutamine increases serum heat shock protein 70 in critically ill patients. Intensive Care Med. 2005 Aug;31(8)1079-86. 31, 1079-1086.

\title{
Резиме
}

\section{Улога на серумскиот HSP 70 во Guillain-Barré синдромот: Прелиминарни истражувања и преглед на литература}

\author{
Аида Лошај-Шала ${ }^{1,2}$, Ана Поцева-Пановска' ${ }^{1}$, Катерина Брезовска ${ }^{1}$, \\ Џанџакомо Берета ${ }^{3 *}$, Љубица Шутуркова ${ }^{1}$, Слободан Апостолски ${ }^{4}$

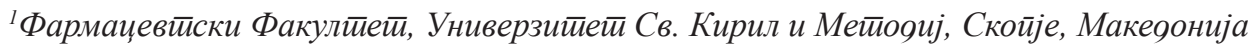

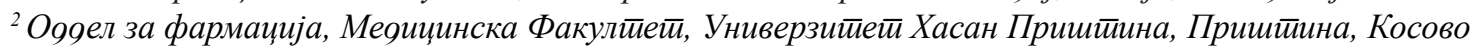

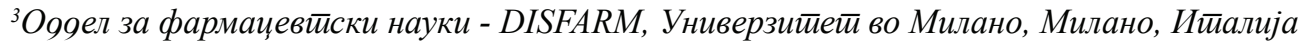 \\ ${ }^{4}$ Амбуланйно невролошка клиника „Айосӣолски“, Белірая, Србија
}

Клучни зборови: серумски Heat Shock протеин 70 (HSP 70), Guillain-Barré синдром (GBS), ELISA

Heat shock протеините (HSP) како еволуциски конзервираната фамилија на протеини учествува во заштитата на клетките при различни видови на стрес. Нивото на протеинот HSP 70 во серуми од пациенти co Guillain-Barre синдром (GBS) не е истражено. Целта на оваа студија е да се определи нивото на HSP 70 во серуми од пациенти co Guillain-Barre синдром (GBS, $\mathrm{n}=21$ ) и да се спореди со нивото на овој протеин во серуми од здрави доброволци $(\mathrm{HC}, \mathrm{n}=9)$ како и во серуми од пациенти со други невролошки заболувања, како мултифокална моторна невропатија (MMN, n=4) и хронична инфламаторна демиенилизирачка полиневропатија (CIDP, n=6). 



\section{INSTRUCTIONS FOR AUTHORS}

Macedonian Pharmaceutical Bulletin is an official publication $\mathrm{f}$ the Macedonian Pharmaceutical Association. The journal publishes original scientific papers, short communications, reviews, mini-reviews and professional papers from all fields of pharmacy and corresponding scientific fields of interest for pharmacy (pharmaceutical and medicinal chemistry, immunology and imunochemistry, molecular biology, pharmaceutical analyses, drug quality control, pharmaceutical technology, pharmacoinformatics, pharmacoeconomics, biopharmacy, pharmacology, applied botany, pharmacognosy, toxicology, clinical pharmacy, food and nutrition, physical pharmacy, organical synthesis, social pharmacy, history of pharmacy etc.). Papers from all areas of medical and other life sciences are also welcomed.

The Macedonian Pharmaceutical Bulletin, also, publishes and other contributions (recommendations and announcements, reports of meetings, important events and dates, book reviews, various rubrics).

\section{Types of paper}

Original scientific papers (full length manuscripts) should contain own unpublished results of completed original scientific research.

Short communications also should contain completed but briefly presented results of original scientific research. The article should be prepared as described for full length manuscripts, except for the following: the number of pages should not exceed 10 (including 2 illustrations, figures or tables). An Abstract should be included as well as a full reference list.

Reviews and mini-reviews are written at the invitation of the Editorial Board. "Mini-reviews" of a topic are especially welcome.

They should be surveys of the investigations and knowledge of several authors in a given research area, the competency of the authors of the reviews being assured by their own published results.

Professional papers report on useful practical results which are not original but help the results of the original scientific research to be adopted into practical use. Professional papers might be based on the elaborating of theoretical data

\section{Language}

Original scientific papers, short communications, reviews and mini-reviews should be written in good English (American or British usage is accepted, but not a mixture of these), while professional papers and all other contributions may be submitted in Macedonian.

\section{Submission declaration}

Submission of an article implies that the work described has not been published previously (except in the form of an abstract or as part of a published lecture or academic thesis), that it is not under consideration for publication elsewhere, that its publication is approved by all authors and tacitly or explicitly by the responsible authorities where the work was carried out, and that, if accepted, it will not be published elsewhere in the same form, in English or in any other language.

\section{Policy and ethics}

The work described in your article must have been carried out in accordance with The Code of Ethics of the World Medical Association (Declaration of Helsinki) for experiments involving humans http://www.wma.net/ en/30publications/10policies/b3/index.html;

EC Directive 86/609/EEC for animal experiments http:/ec.europa.eu/environment/chemicals/lab animals/ legislation en.htm;

Uniform Requirements for manuscripts submitted to Biomedical journals http://www.icmje.org. This must be stated at an appropriate point in the article.

\section{Submission}

Please submit the manuscript electronically (e-mail address: magl@ff.ukim.edu.mk) as a single PDF file, which will be used in the peer-review process. All correspondence, including notification of the Editor's decision and requests for revision, takes place by e-mail removing the need for a paper trail. 


\section{Referees}

Please submit, with the manuscript, the names, addresses and e-mail addresses of 3 potential referees. Note that the editor retains the sole right to decide whether or not the suggested reviewers are used.

Papers received by the Editorial Board are sent to referees. The suggestions/comments of the referees and Editorial Board are sent to the author(s) for further action. The revised article should be returned to the Editorial Board as soon as possible but in not more than 30 days.

\section{Preparation of manuscripts}

\section{Use of wordprocessing software}

It is important that the file be saved in the native format of the wordprocessor used. The text should be typed (1 $1 / 2$ spaced) on A4 paper with margins of $3.0 \mathrm{~cm}$ on each side in single-column format, font Times New Roman, Mac C Times, Macedonian Times and size 11, Keep the layout of the text as simple as possible. Most formatting codes will be removed and replaced on processing the article. In particular, do not use the wordprocessor's options to justify text or to hyphenate words. However, do use bold face, italics, subscripts, superscripts etc. When preparing tables, if you are using a table grid, use only one grid for each individual table and not a grid for each row. If no grid is used, use tabs, not spaces, to align columns. The electronic text should be prepared in a way very similar to that of conventional manuscripts. To avoid unnecessary errors you are strongly advised to use the "spell-check" and "grammarcheck" functions of your wordprocessor.

The pages in the article should be numbered.

Finally, please create PDF file before sending the article. After acceptance, you will be asked to supply the article as wordprocessing document (zip-file).

\section{Appendices}

If there is more than one appendix, they should be identified as A, B, etc. Formulae and equations in appendices should be given separate numbering: Eq. (A.1), Eq. (A.2), etc.; in a subsequent appendix, Eq. (B.1) and so on. Similarly for tables and figures: Table A.1; Fig. A.1, etc.

\section{Abbreviations}

Define abbreviations that are not standard in this field in a footnote to be placed on the first page of the article. Such abbreviations that are unavoidable in the abstract must be defined at their first mention there, as well as in the footnote. Ensure consistency of abbreviations throughout the article.

\section{Units}

Follow internationally accepted rules and conventions: use the international system of units (SI). If other units are mentioned, please give their equivalent in SI.

The names of substances should be in accordance with the IUPAC recommendations and rules or Chemical $A b$ stracts practice.

\section{Math formulae}

Present simple formulae in the line of normal text where possible and use the solidus (/) instead of a horizontal line for small fractional terms, e.g., $\mathrm{X} / \mathrm{Y}$. In principle, variables are to be presented in italics.

\section{Footnotes}

Footnotes should be used sparingly. Number them consecutively throughout the article, using superscript Arabic numbers. Many wordprocessors build footnotes into the text, and this feature may be used. Should this not be the case, indicate the position of footnotes in the text and present the footnotes themselves separately at the end of the article. Do not include footnotes in the Reference list.

\section{Table footnotes}

Indicate each footnote in a table with a superscript lowercase letter.

\section{Figures}

Figures (photographs, diagrams and sketches) and structural formulae should each be given on a separate sheet (the place to which they belong in the text should be indicated). The figures should be numbered in Arabic numerals (e.g. Fig. 1). Ensure that each illustration has a caption. Supply all captions separately, not attached to the figure. A caption should comprise a brief title (not on the figure itself) and a description of the illustration. Keep text in the illustrations themselves to a minimum but explain all symbols and abbreviations used.

Please submit the pictures in a black and white version.

Tables

The tables should be numbered in Arabic numerals (e.g. Table 1) and each should be given on a separate sheet (the place to which they belong in the text should be indicated). Number tables consecutively in accordance with their appearance in the text. Place footnotes to tables below the table body and indicate them with superscript lowercase letters. Be sparing in the use of tables and ensure that the data presented in the tables are not duplicated elsewhere in the article. 


\section{Article structure}

Manuscript should contain: title, abstract, key words, introduction, material and methods, results and discussion, conclusion, acknowledgment (if desired) references and summary.

\section{Subdivision}

Divide your article into clearly defined sections (Abstract, Introduction, Material and methods. etc.). Any section or subsection may be given a brief heading. Each heading should appear on its own separate line.

\section{Essential title page information}

Papers should be preceded by a title page comprising: the title, the complete name(s) of the authors, and the author's affiliations.

Title. Concise and informative. Avoid abbreviations and formulae where possible.

Author names and affiliations. Where the family name may be ambiguous (e.g., a double name), please indicate this clearly. Present the authors' affiliation addresses (where the actual work was done) below the names. Indicate all affiliations with a lower-case superscript arabic number immediately after the author's name and in front of the appropriate address. Provide the full postal address of each affiliation, including the country name of each author.

Corresponding author. Clearly indicate (with *) who will handle correspondence at all stages of refereeing and publication, also post-publication. Ensure that telephone and fax numbers (with country and area code) are provided in addition to the e-mail address and the complete postal address.

Each paper must begin with an Abstract which should not exceed more than 250 (original scientific and professional papers) or 100 (short communications) words. The abstract should state briefly the purpose of the research, the principal results and major conclusions. References should be avoided, but if essential, then cite the author(s) and year(s). Also, non-standard or uncommon abbreviations should be avoided, but if essential they must be defined at their first mention in the abstract itself. Immediately after the abstract, provide a list of 3 to 6 keywords arranged in the order according to their importance.

\section{Introduction}

State the objectives of the work and provide an adequate background, avoiding a detailed literature survey or a summary of the results.

\section{Material and methods}

Provide sufficient detail to allow the work to be reproduced. Methods already published should be indicated by a reference: only relevant modifications should be described. Manuscripts which are related to theoretical studies, instead of Material and methods, should contain a sub-heading and the Theoretical background where the necessary details for verifying the results obtained should be stated.

\section{Results}

Results should be clear and concise.

\section{Discussion}

This should explore the significance of the results of the work, not repeat them. A combined Results and Discussion section is often appropriate. Avoid extensive citations and discussion of published literature.

\section{Conclusions}

The main conclusions of the study may be presented in a short Conclusions section, which may stand alone or form a subsection of a Discussion or Results and Discussion section.

\section{Acknowledgements}

Collate acknowledgements in a separate section at the end of the article before the references and do not, therefore, include them on the title page, as a footnote to the title or otherwise. List here those individuals who provided help during the research (e.g., providing language help, writing assistance or proof reading the article, etc.).

\section{References}

\section{Citation in text}

Please ensure that every reference cited in the text is also present in the reference list (and vice versa). Any references cited in the abstract must be given in full. Unpublished results and personal communications are not recommended in the reference list, but may be mentioned in the text. If these references are included in the reference list they should follow the standard reference style of the journal and should include a substitution of the publication date with either "Unpublished results" or "Personal communication". Citation of a reference as "in press" implies that the item has been accepted for publication and a copy of the title page of the relevant article must be submitted.

\section{Web references}

As a minimum, the full URL should be given and the date when the reference was last accessed. Any further information, if known (DOI, author names, dates, reference to a source publication, etc.), should also be given. Web references can be listed separately (e.g., after the reference list) under a different heading if desired, or can be included in the reference list. 


\section{Reference style}

Text: All citations in the text should refer to:

1. Single author: the author's name (without initials, unless there is ambiguity) and the year of publication;

2. Two authors: both authors' names and the year of publication;

3. Three or more authors: first author's name followed by "et al." and the year of publication.

Citations may be made directly (or parenthetically). Groups of references should be listed first alphabetically, then chronologically.

Examples: "as demonstrated (Allan, 1996a, 1996b, 1999; Allan and Jones, 1995). Kramer et al. (2000) have recently shown...."

List: References should be arranged first alphabetically and then further sorted chronologically if necessary. More than one reference from the same author(s) in the same year must be identified by the letters "a", "b", "c", etc., placed after the year of publication.

\section{Examples:}

Reference to a journal publication:

Van der Geer, J., Hanraads, J.A.J., Lupton, R.A., 2000. The art of writing a scientific article. J. Sci. Commun. 163, 51-59.

Reference to a book:

Strunk Jr., W., White, E.B., 1979. The Elements of Style, third ed. Macmillan, New York.

Reference to a chapter in an edited book:

Mettam, G.R., Adams, L.B., 1999. How to prepare an electronic version of your article, in: Jones, B.S., Smith, R.Z. (Eds.), Introduction to the Electronic Age. E-Publishing Inc., New York, pp. 281-304.

Journal abbreviations source

Journal names should be abbreviated according to

Index Medicus journal abbreviations: http://www.nlm. nih.gov/tsd/serials/lji.html

List of serial title word abbreviations: http://www.issn. org/2-22661-LTWA-online.php;

CAS (Chemical Abstracts Service): http://www.cas. org/sent.html.

Manuscripts written in English should contain a Summary in Macedonian at the end of the paper. The summary should contain: title, author(s) full-name(s), surname(s), author's affiliations (institution and address), key words and abstract. Professional papers written in Macedonian should contain a summary in English in which the same data should be included.

\section{Submission checklist}

It is hoped that this list will be useful during the final checking of an article prior to sending it to the journal's
Editor for review. Please consult this Guide for Authors for further details of any item.

Ensure that the following items are present:

One Author designated as corresponding Author:

- E-mail address

- Telephone and fax numbers

- All necessary files have been uploaded

- Keywords

- All figure captions

- All tables (including title, description, footnotes)

- Further considerations: Manuscript has been "spellchecked" and "grammar-checked"

- $\quad$ References are in the correct format for this journal

- All references mentioned in the Reference list are cited in the text, and vice versa

- Permission has been obtained for use of copyrighted material from other sources (including the Web)

\section{After acceptance}

Proofs

One set of page proofs (as PDF files) will be sent by e-mail to the corresponding author. Please list the corrections and return them via e-mail. If, for any reason, this is not possible, then mark the corrections and any other comments on a printout of your proof and return by fax, or scan the pages and e-mail, or by post. Please use this proof only for checking the typesetting, editing, completeness and correctness of the text, tables and figures. Significant changes to the article as accepted for publication will not be accepted.

We will do everything possible to get your article published quickly and accurately. Therefore, it is important to ensure that all of your corrections are sent back to us in one communication: please check carefully before replying, as inclusion of any subsequent corrections cannot be guaranteed. Proofreading is solely your responsibility. Note that Macedonia Pharmaceutical Bulletin may proceed with the publication of your article if no response is received.

\section{Offprints}

The corresponding author, at no cost, will be provided with a PDF file of the article by e-mail. The PDF file is a watermarked version of the published article and includes a cover sheet with the journal cover image.

Additional paper offprints can also be ordered for an extra charge. 